Fall 1973

\title{
1973 Miracle Yearbook
}

\section{Cedarville College}

Follow this and additional works at: https://digitalcommons.cedarville.edu/yearbooks

Part of the Higher Education Commons, Organizational Communication Commons, and the Public Relations and Advertising Commons

\section{Recommended Citation}

Cedarville College, "1973 Miracle Yearbook" (1973). Yearbooks. 24.

https://digitalcommons.cedarville.edu/yearbooks/24

This Book is brought to you for free and open access by DigitalCommons@Cedarville, a service of the Centennial Library. It has been accepted for inclusion in Yearbooks by an authorized administrator of DigitalCommons@Cedarville. For more information, please contact digitalcommons@cedarville.edu. 

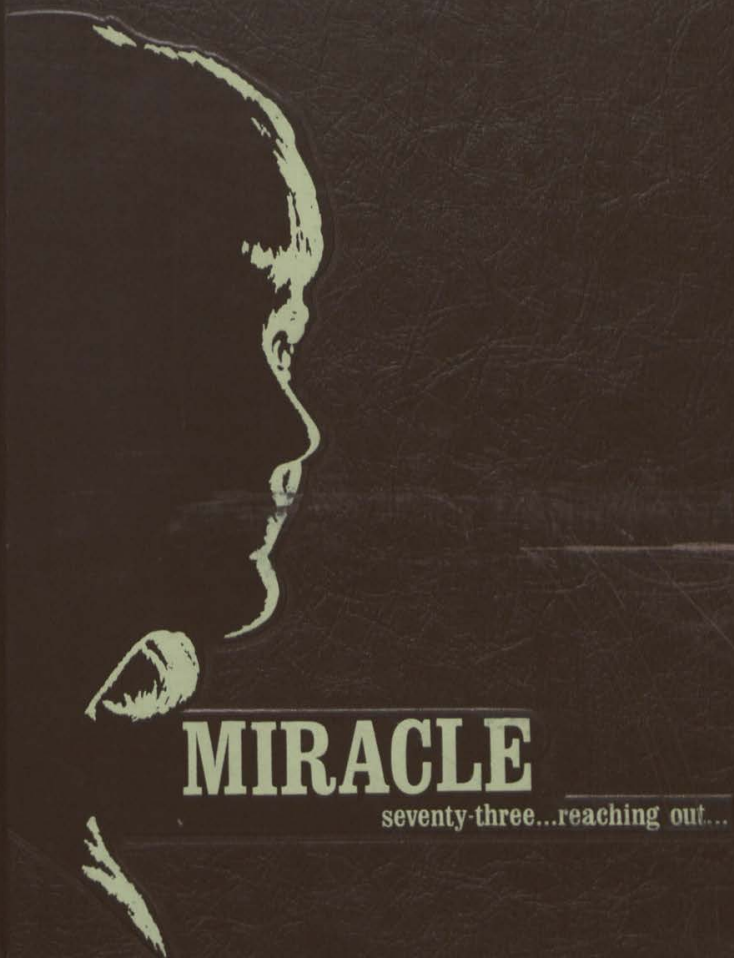

seventy three...reaching out... 


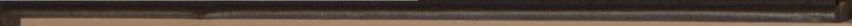






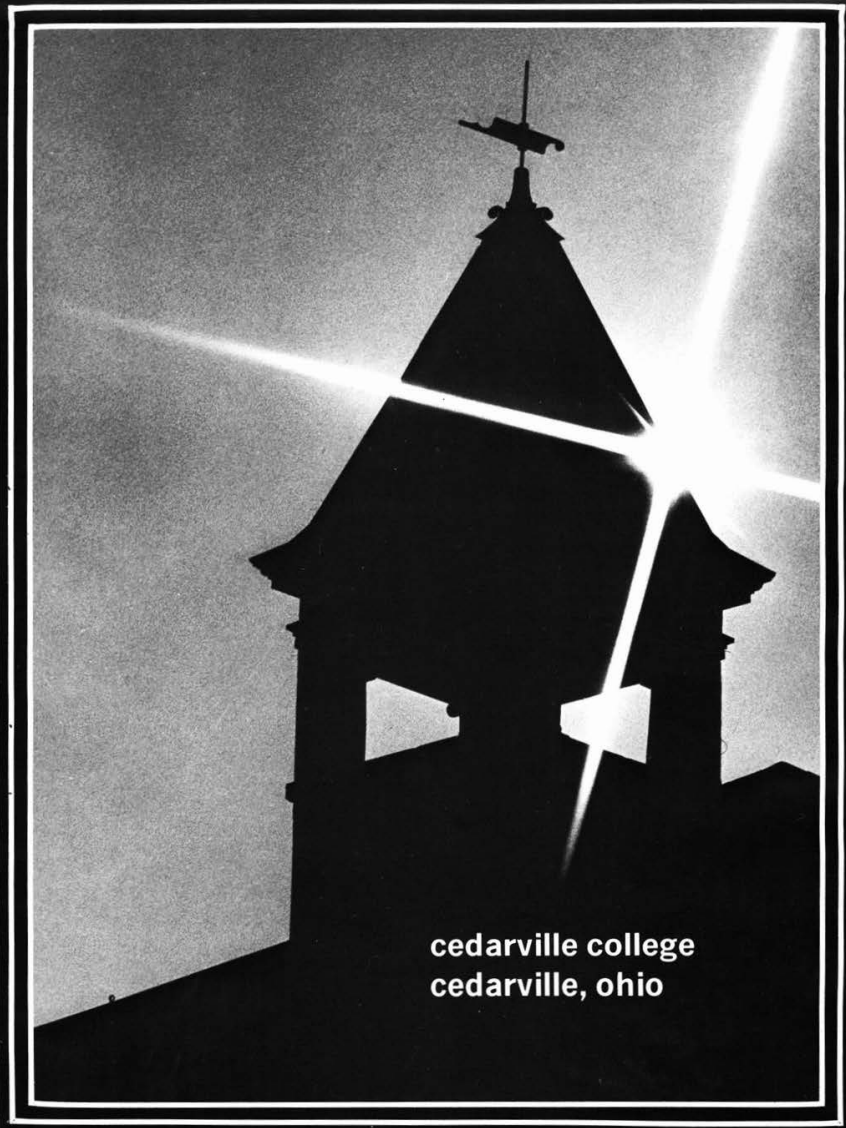


A
$378-7714$
2387
1973

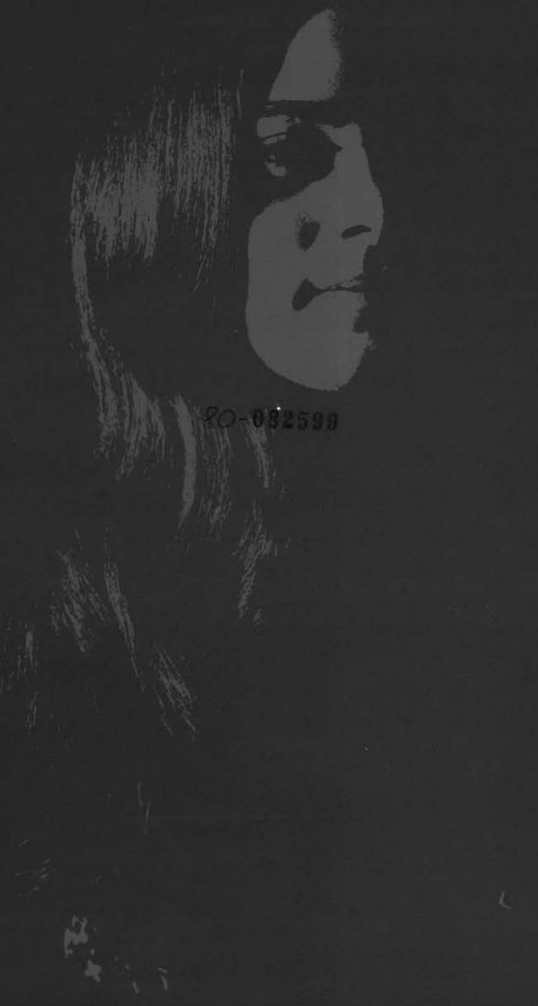

25) $190-082593$
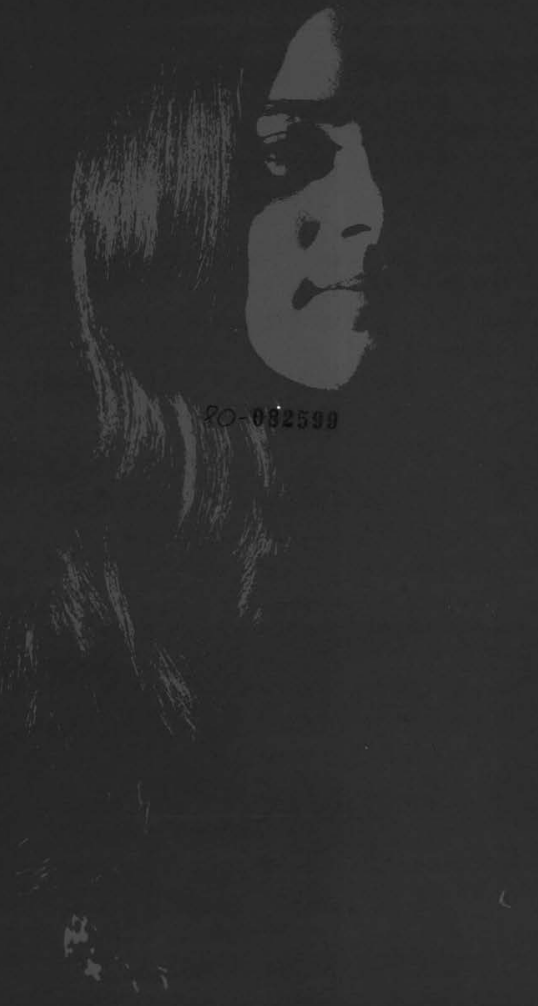

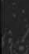

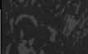

to 
cedarville college

it's a place, a thing, a home,

it's a time for reaching out academically,

socially,

physically,

spiritually.

cedarville college

it's yours and you.

'brethren, i count not myself to have apprehended; but this one thing i do, forgetting those things which are behind, and reaching forth unto those things which are before, i press toward the mark for the prize of the high calling of God in Christ Jesus."

Phil 3: 13-14 

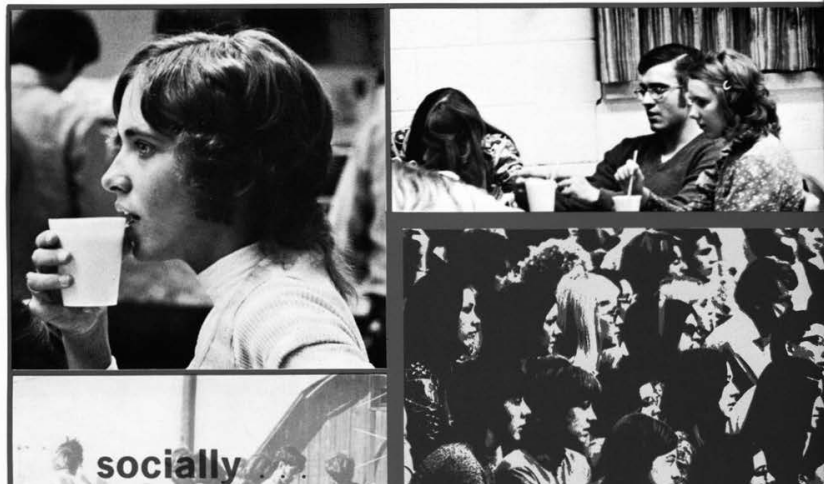

3

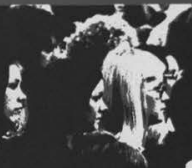

$\frac{1}{2}$<smiles>[3H]</smiles>

1

We all reach out socially We do it without much thought: We all desire to bejaccepted and to accept. We hate the cold feeling of foneliness. We crave the warmth of triendship.
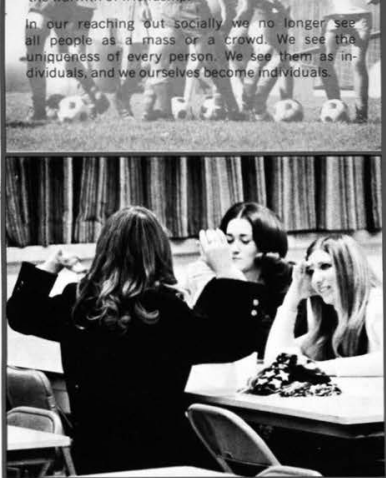

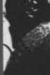<smiles>[BH3-]</smiles>

t.<smiles>[121IH]</smiles>

4

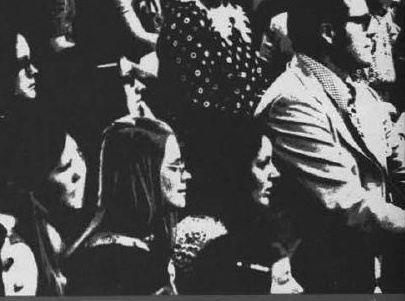

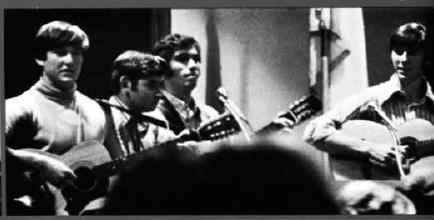




\section{Thaves \\ 웅}

.

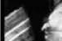

\section{a \\ ace \\ c. \\ N}

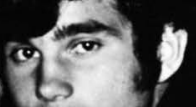
सक से 35

सक ज्ञ (1) 3 : F 100 1 t 1.3 f

a 5

- ard of

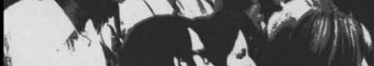
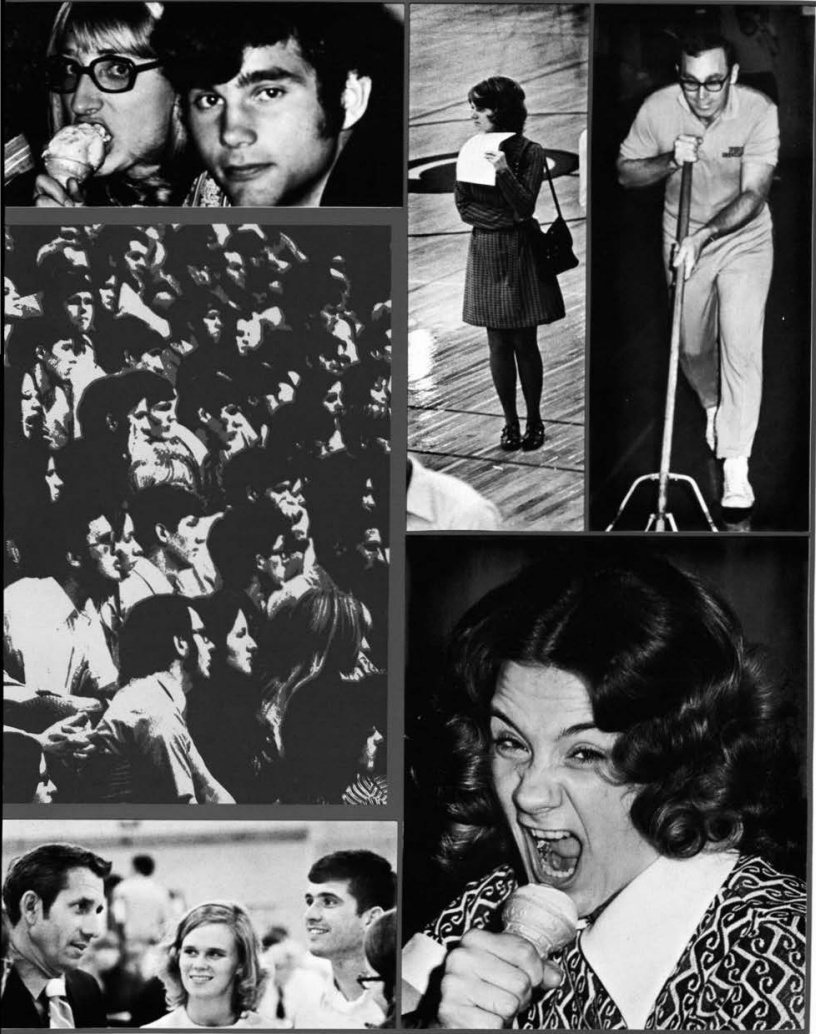

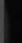




\section{physically ...}

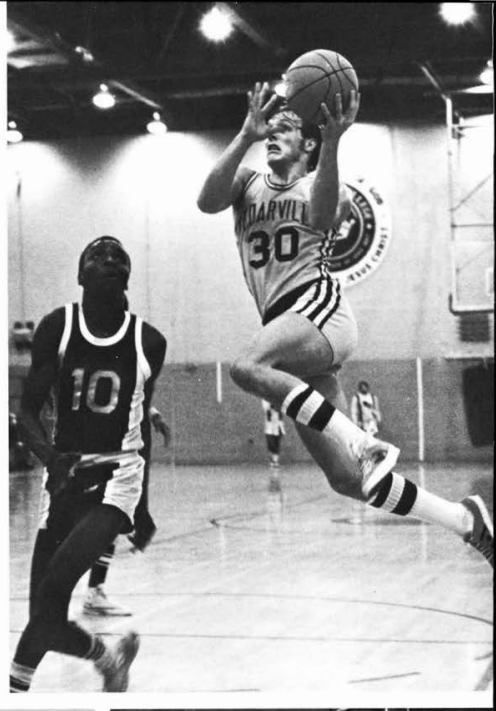

When we reach out physically we extend ourselves to the limit and then beyond. We fail to see the idea of quitting. We push ourselves to do the best. We strive for perfection. It all seems so far away. Yet we continue and never give up. For if we stop. then have we failed.

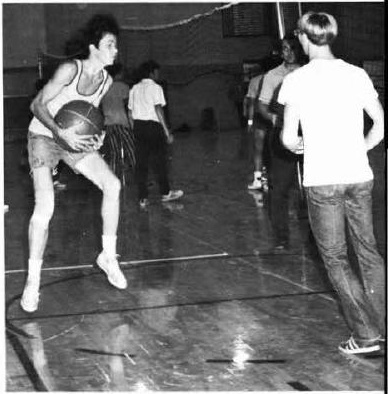



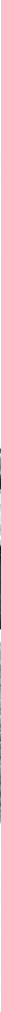


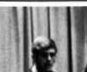

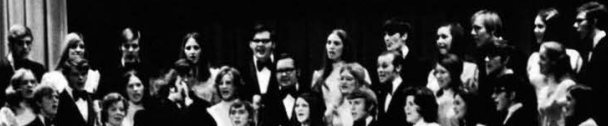
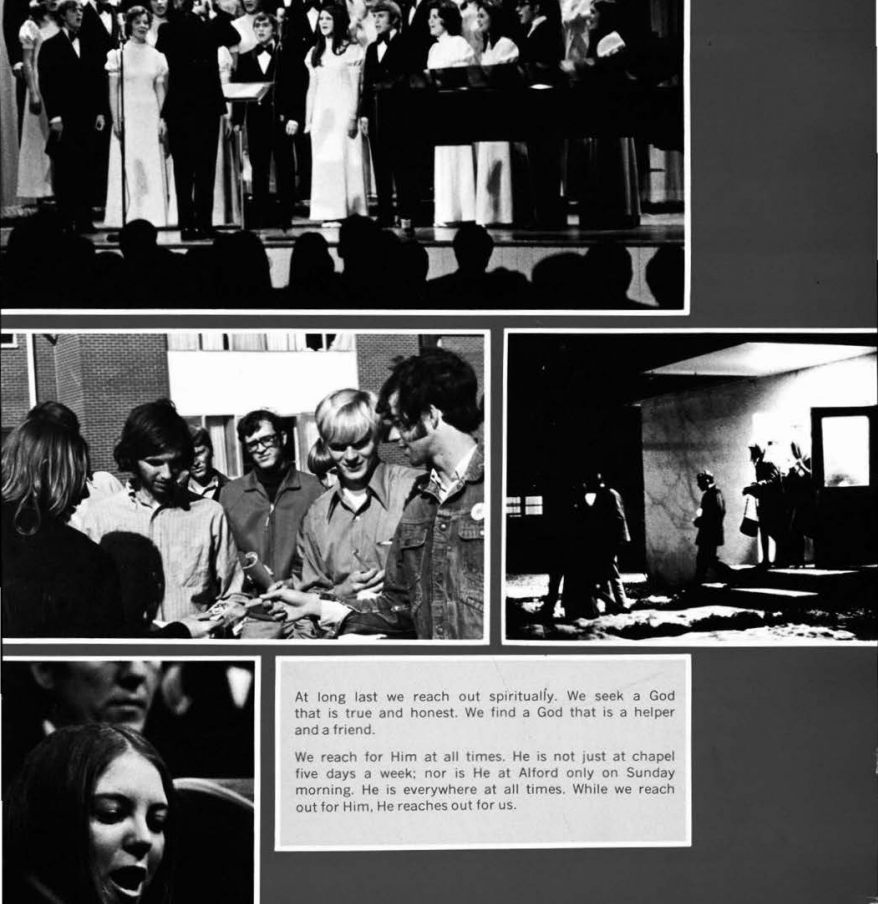

At long last we reach out spiritually. We seek a God that is true and honest. We find a God that is a helper and $a$ friend.

We reach for $\mathrm{Him}$ at all times. $\mathrm{He}$ is not just at chapel five days a week: nor is $\mathrm{He}$ at Alford only on Sunday morning. He is everywhere at all times. While we reach out for $\mathrm{Him}$, He reaches out for us. 

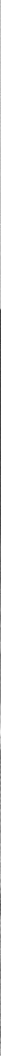

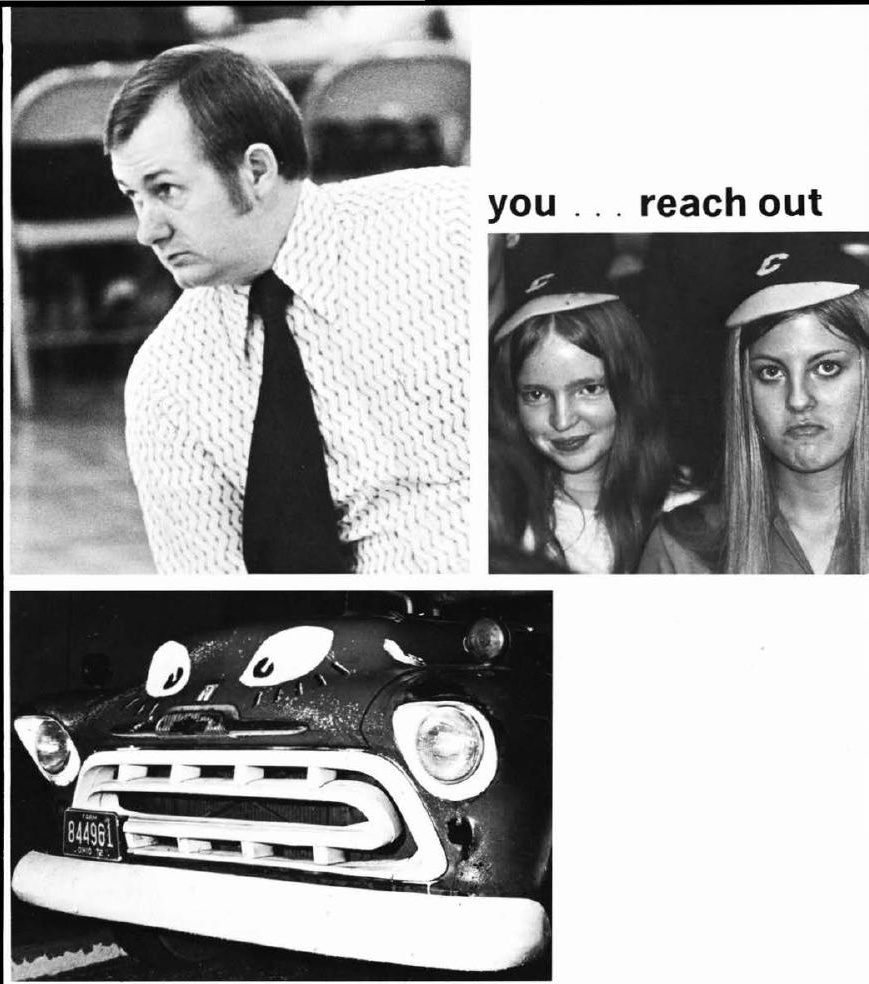

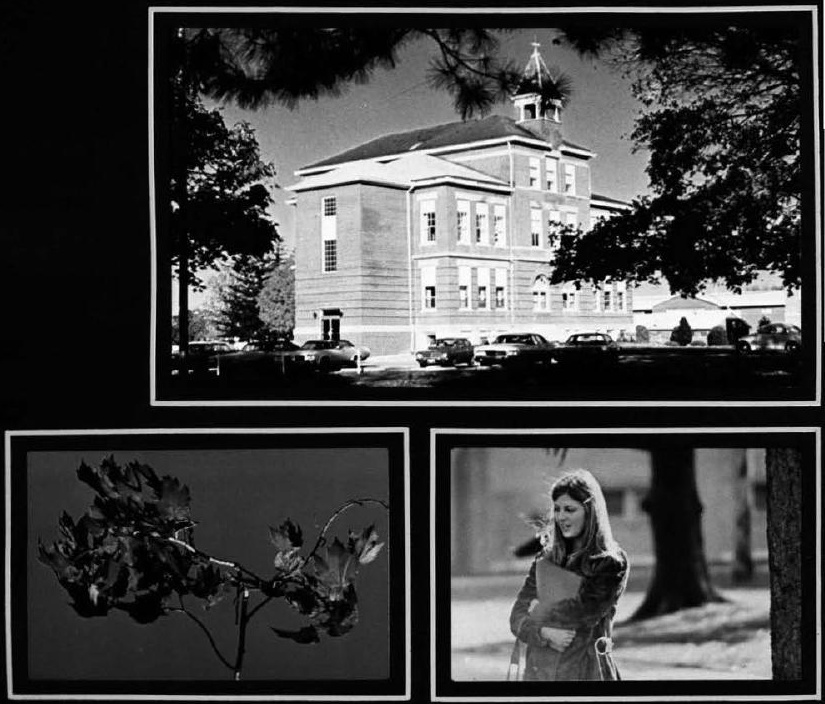

\section{autumn is ...}




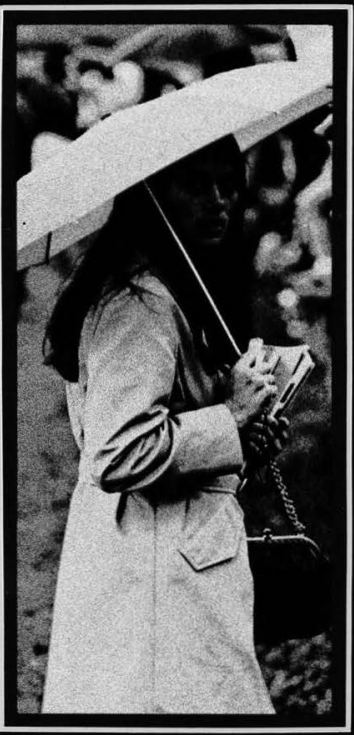

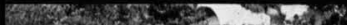

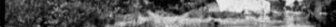

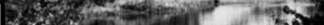

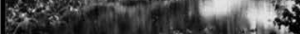

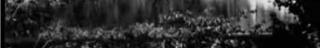

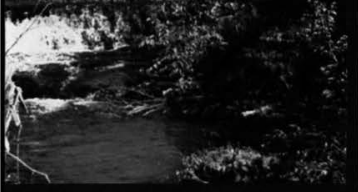



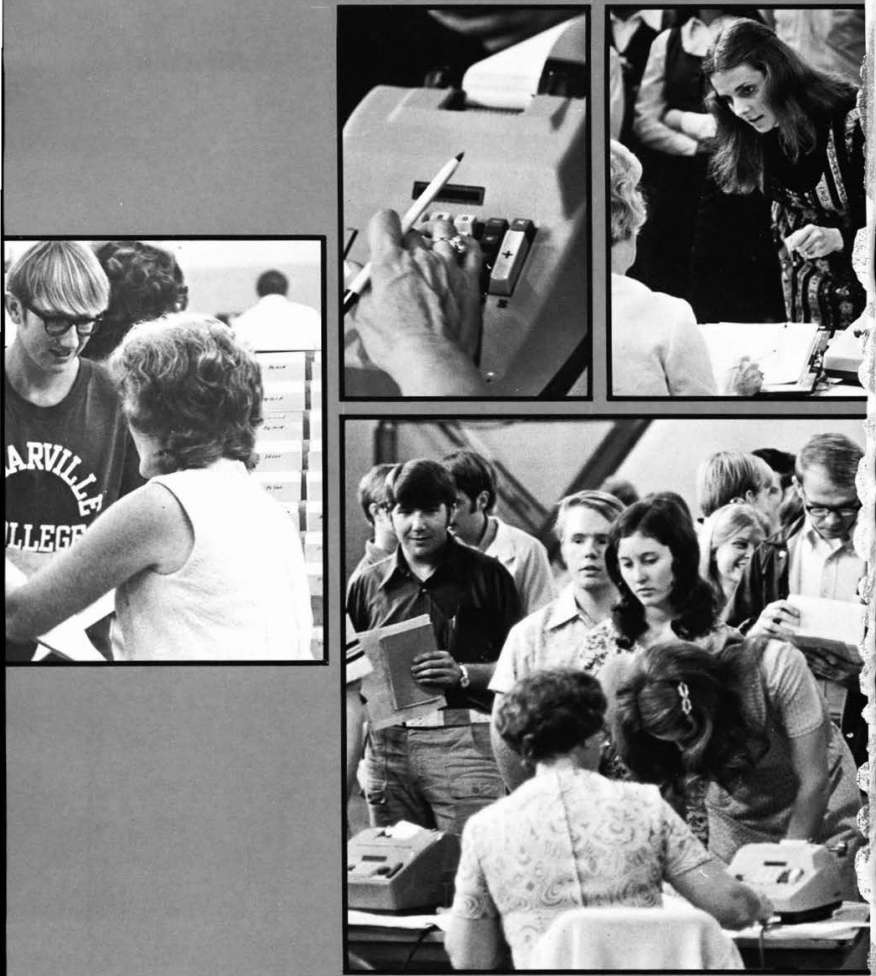

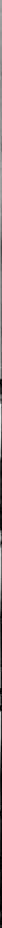

pi delta 
who ... who's who

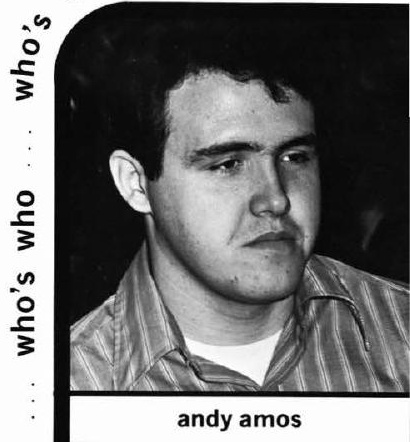

$\frac{8}{3}$

,

을

(1)

.

\section{don davis}


who's who ... who's who ... who's who .... who

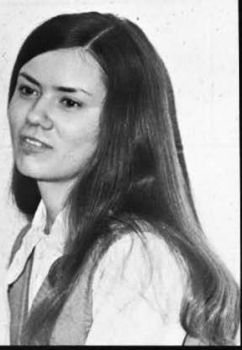

rosalie howard

eldon sarver

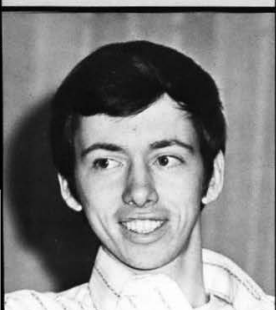



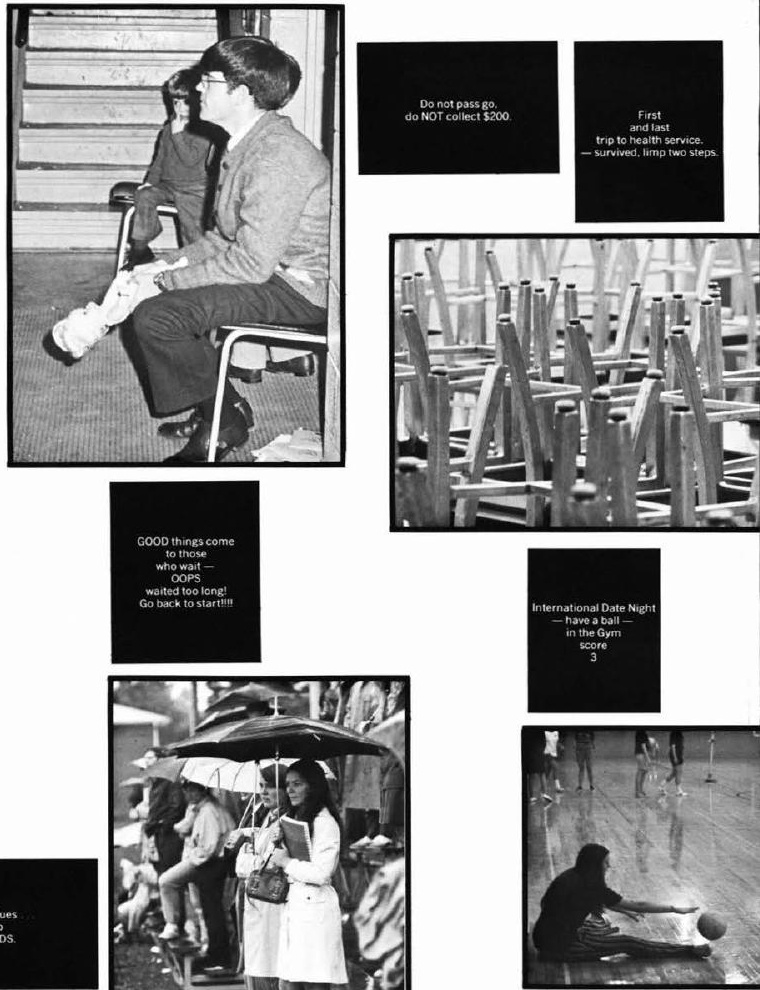

Mid-quarter blues half step

BACKWARDS
GOOD things come

to those

who wait -

OOPS

waited too long!

Go back to startil!
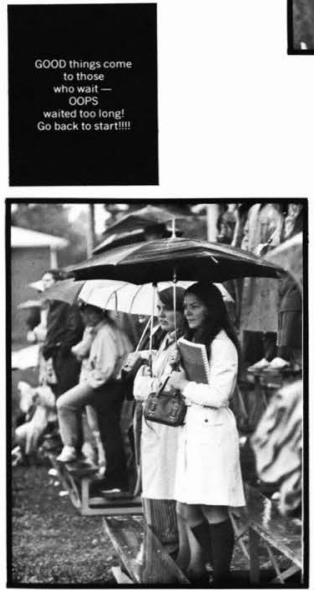
4:00 a.m. Term

Paper due

Advance into FINALS stage.

SENIOR PANIC!

Go back 8 spaces.

$$
\text { o }
$$

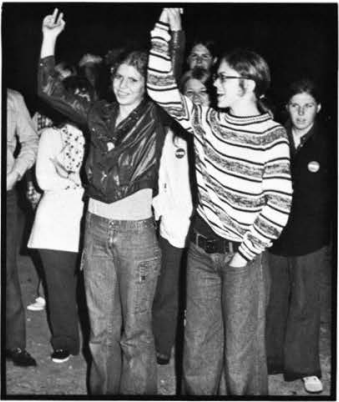

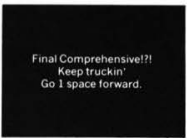
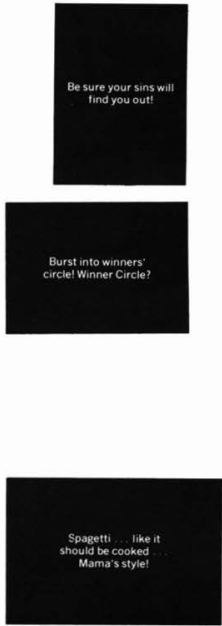

game of college life 25 

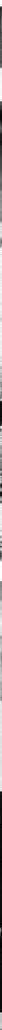

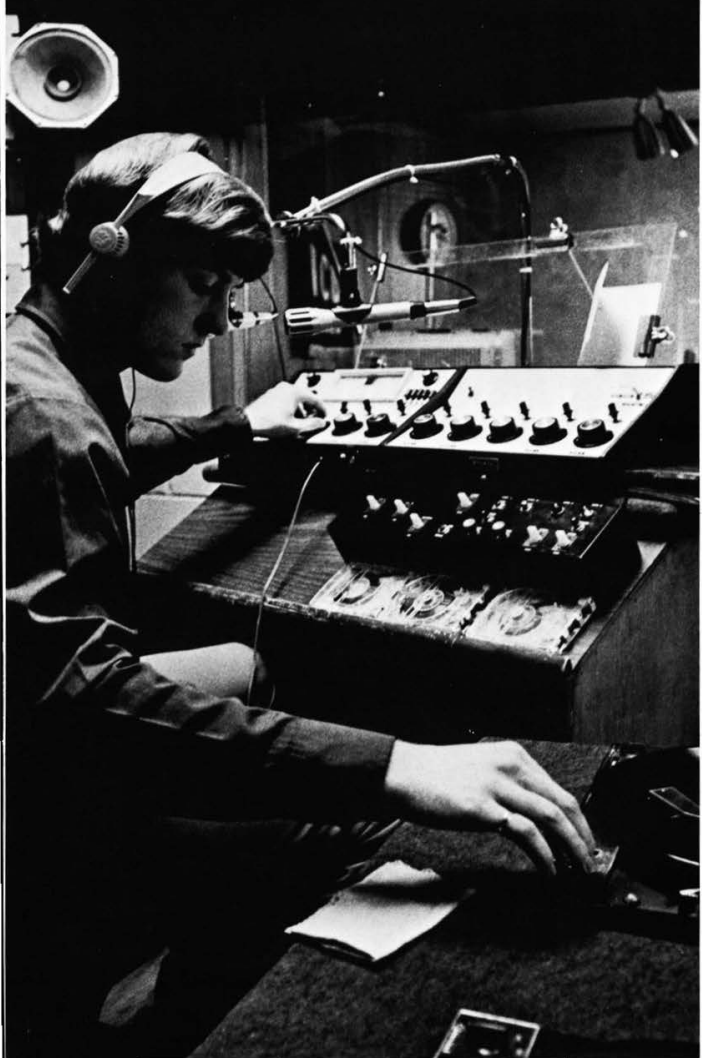


\section{stereo}
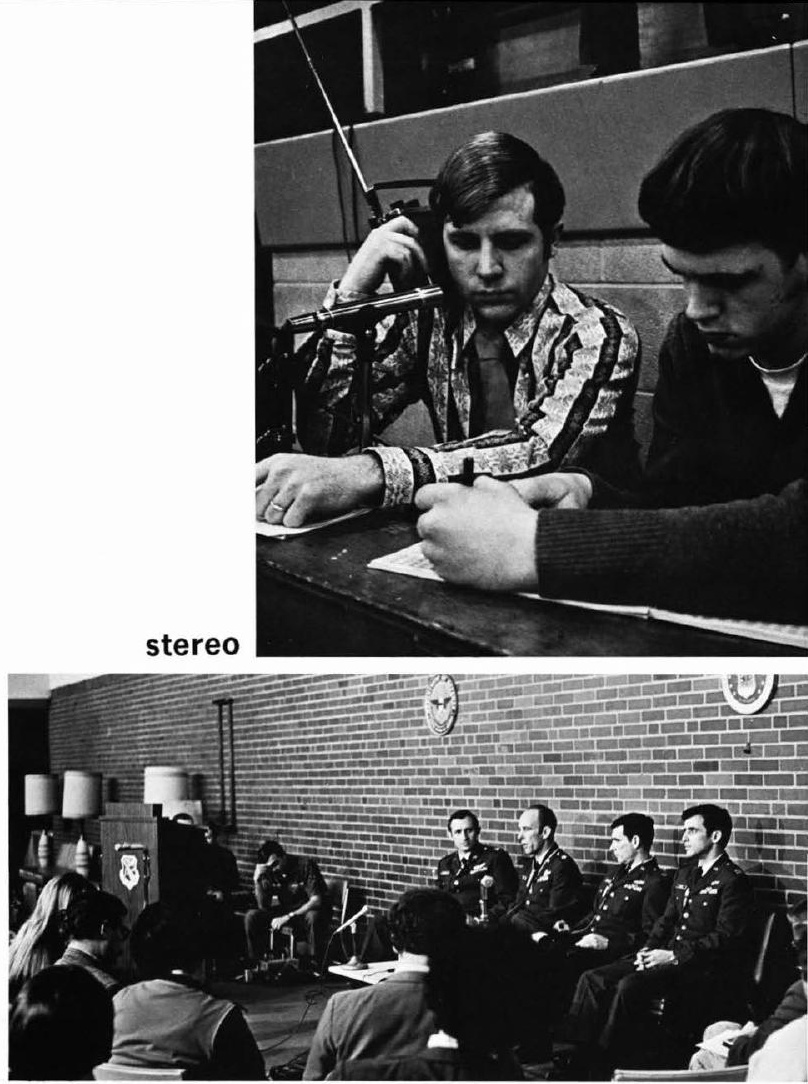


\section{my three angels}
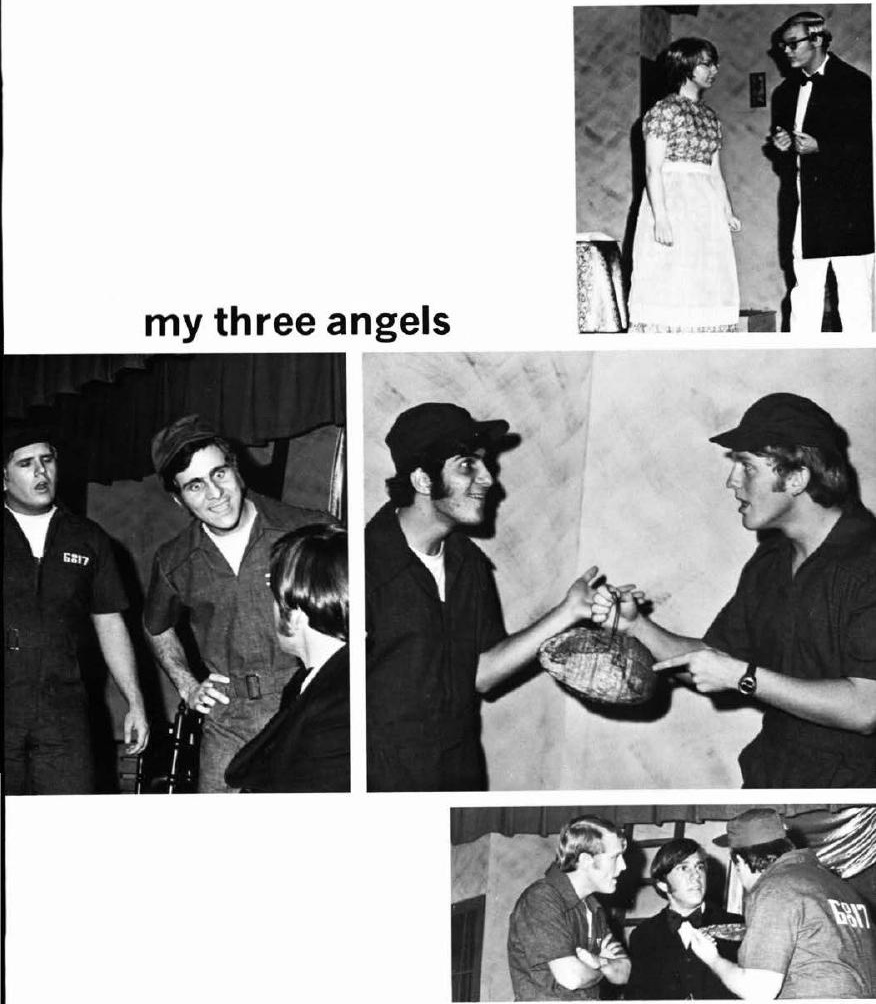


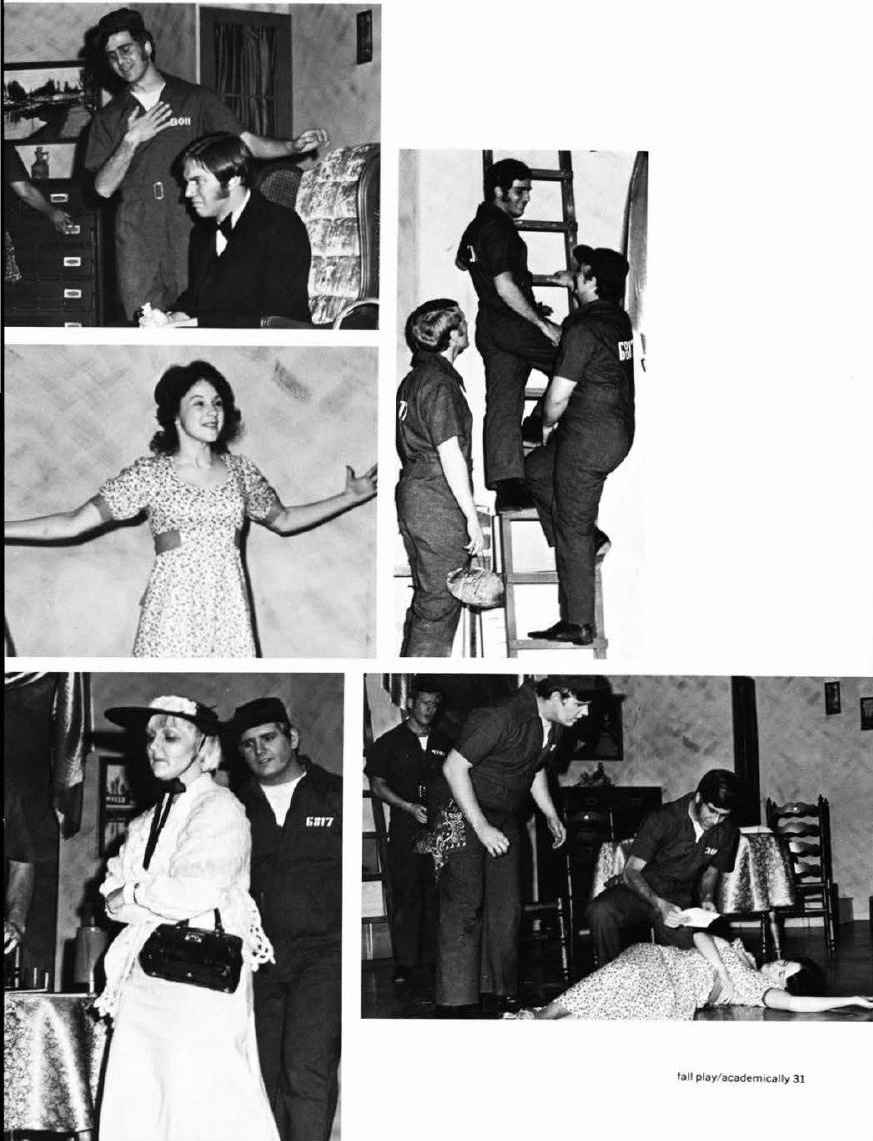




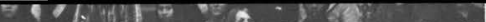

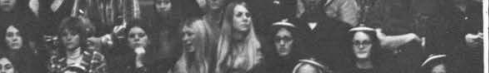
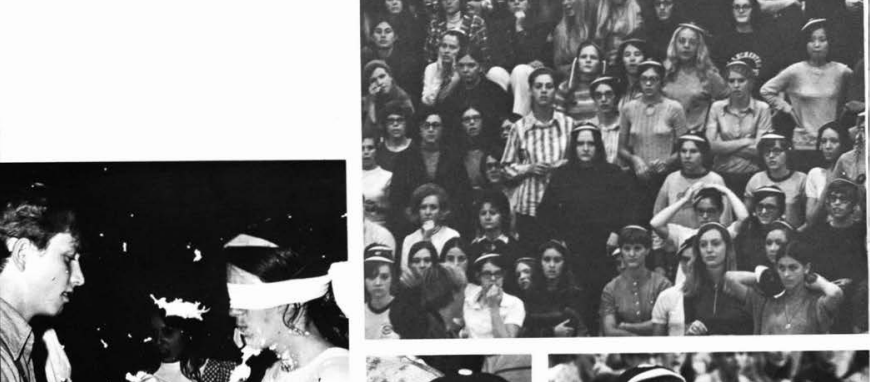

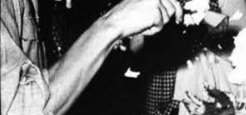

(1),$\ldots$
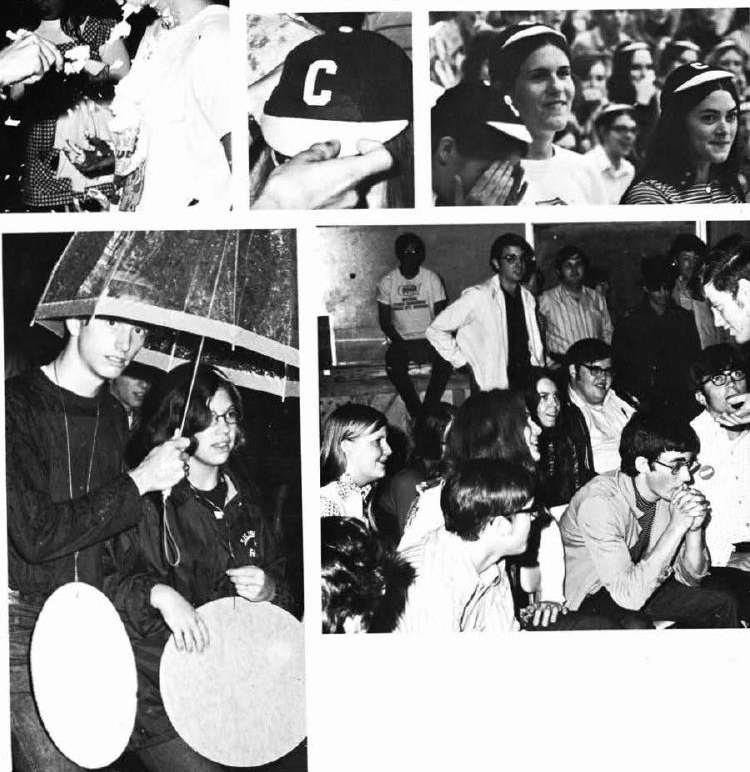


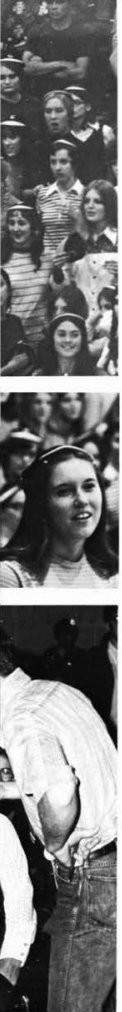

\section{freshmen initiation}
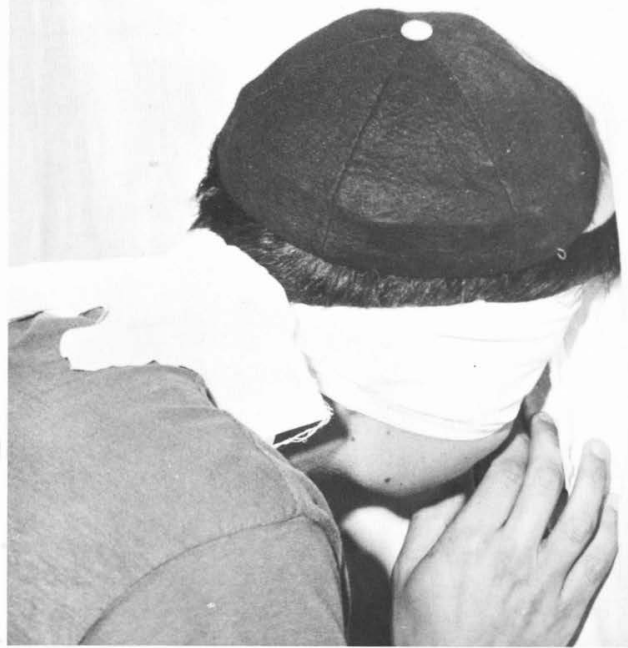


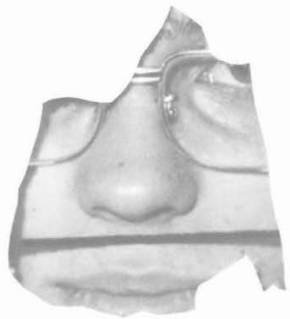




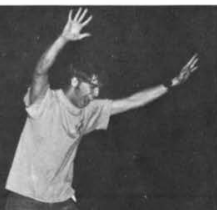

\section{freshmen initiation}
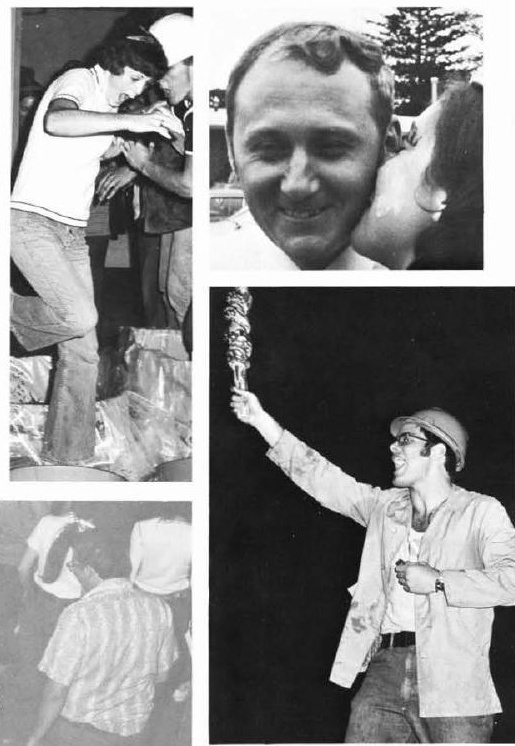
new student talent night
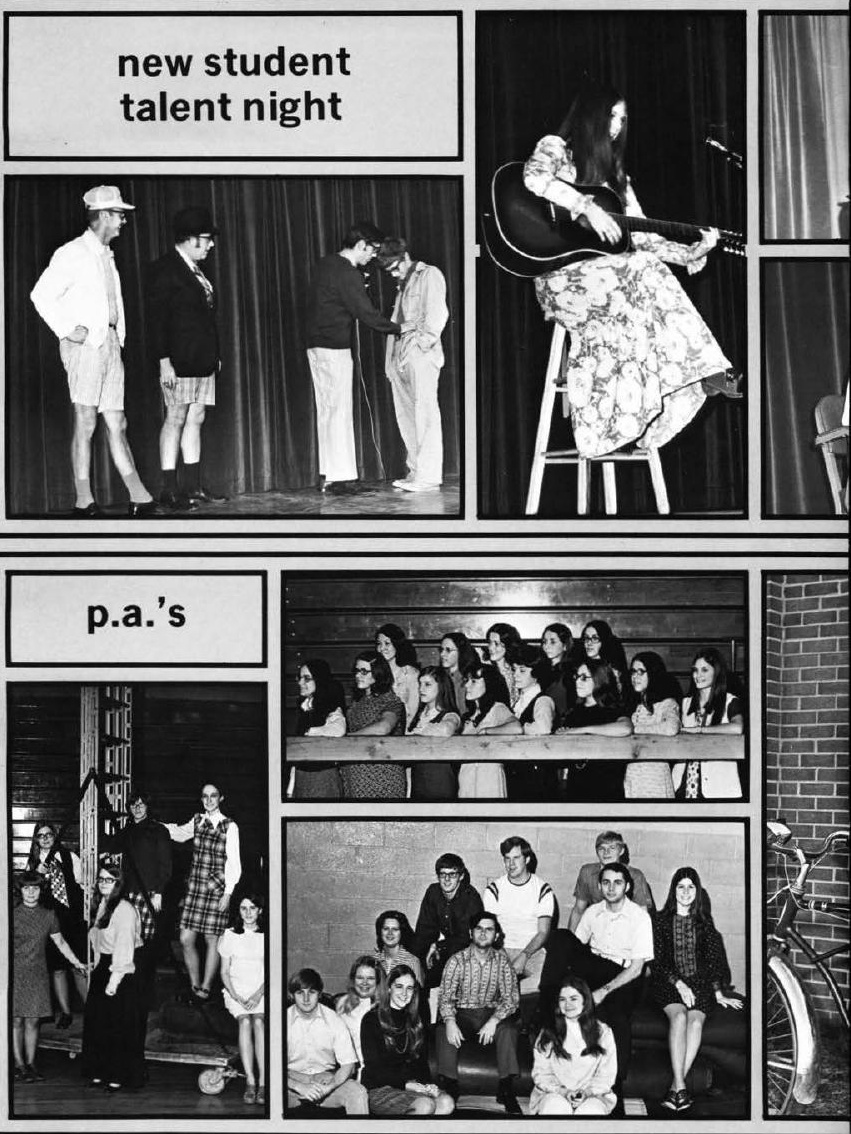


\section{cedar?}

What was the election of Cedar What? It was a not November night in the gym It was the Classics Quartet. It was an as: as secret service men. It was promises It was a wild motorcycle ride. It was a a drawl. It was the conservatives against the liberals. It was the Dixie and Guru It was Phipps and Frank. It was a Cedar ville College student body totally involved and excited

What was Cedar What?? It was decent! sassination attempt. It was the U.E.W.A.A man short of stature. It was a women with
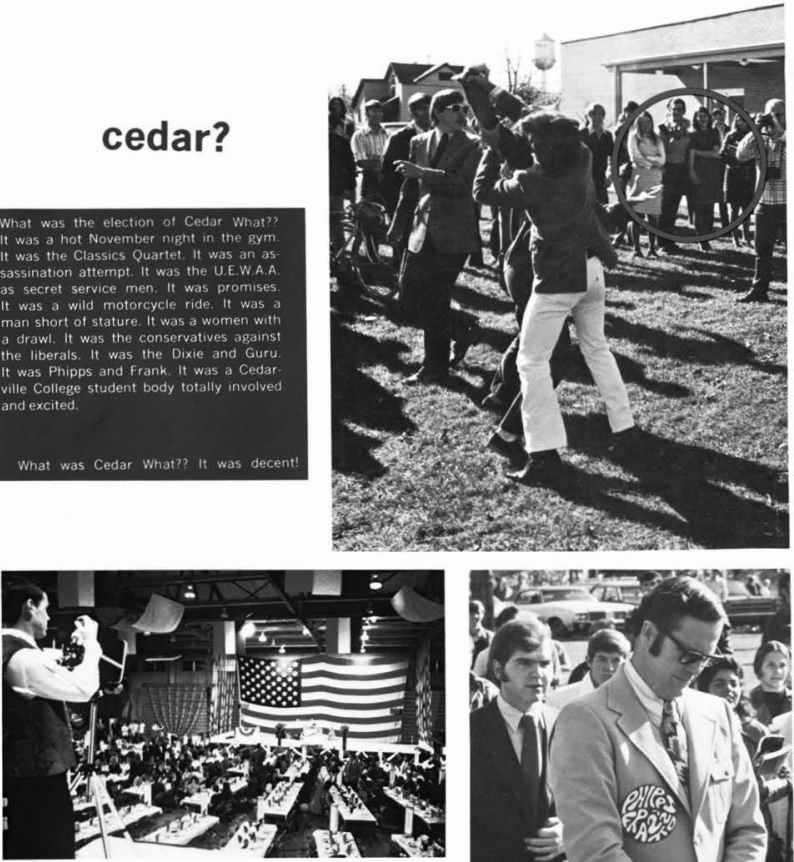

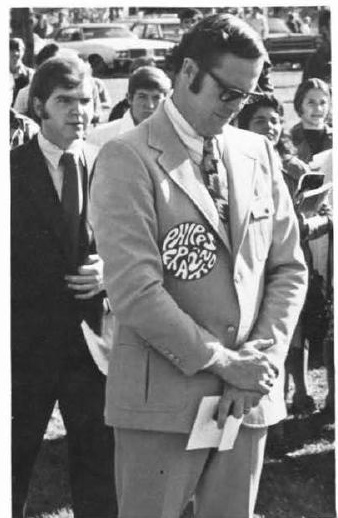




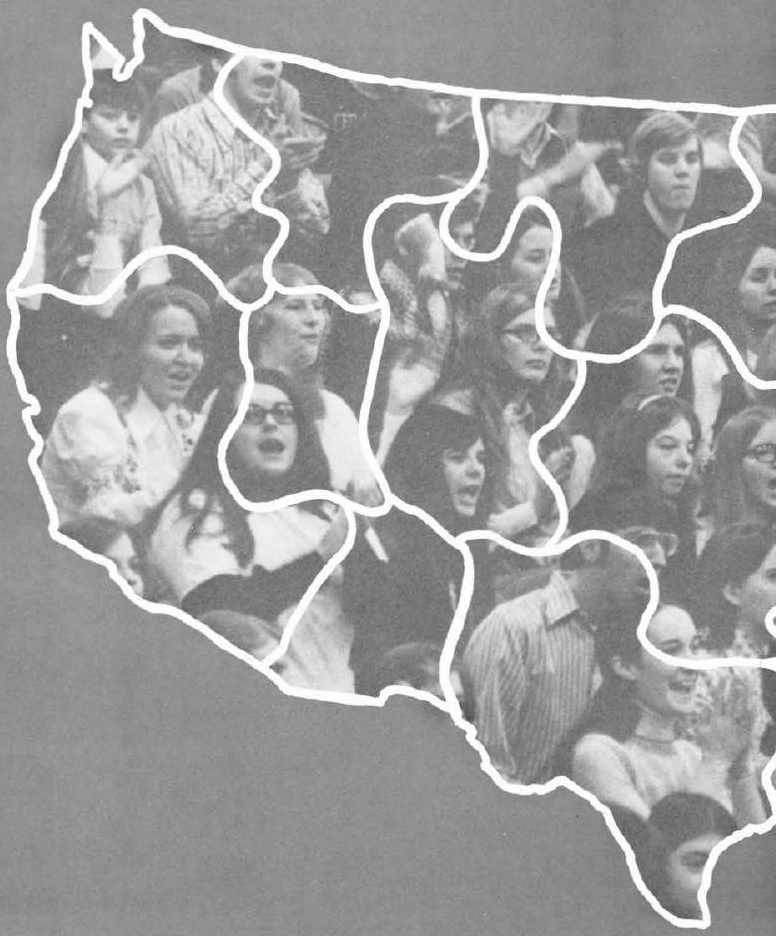




\section{homecoming '72}
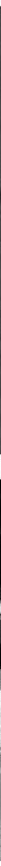

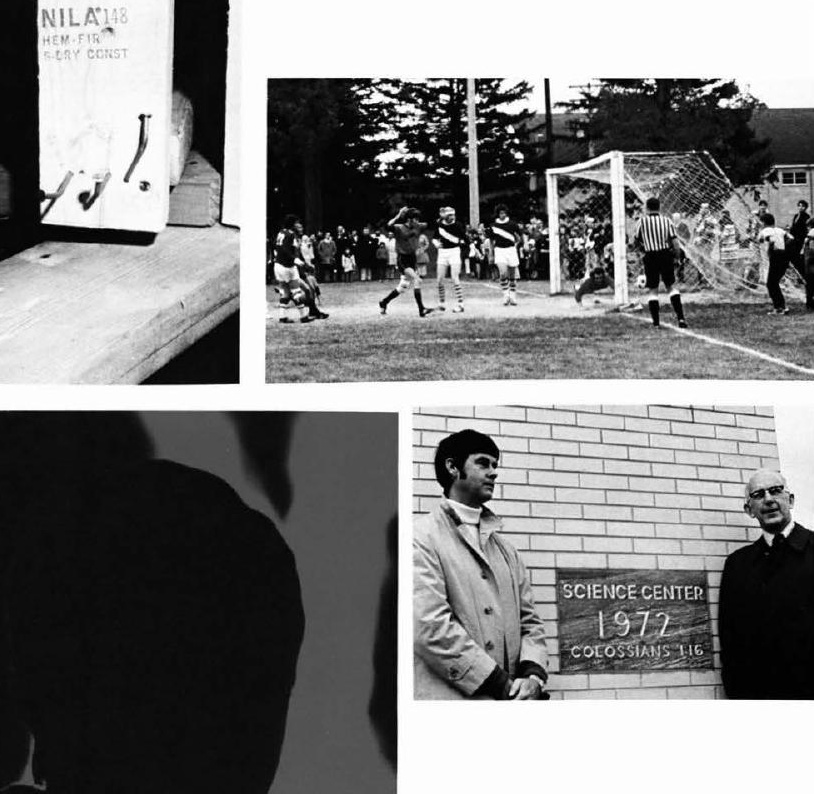

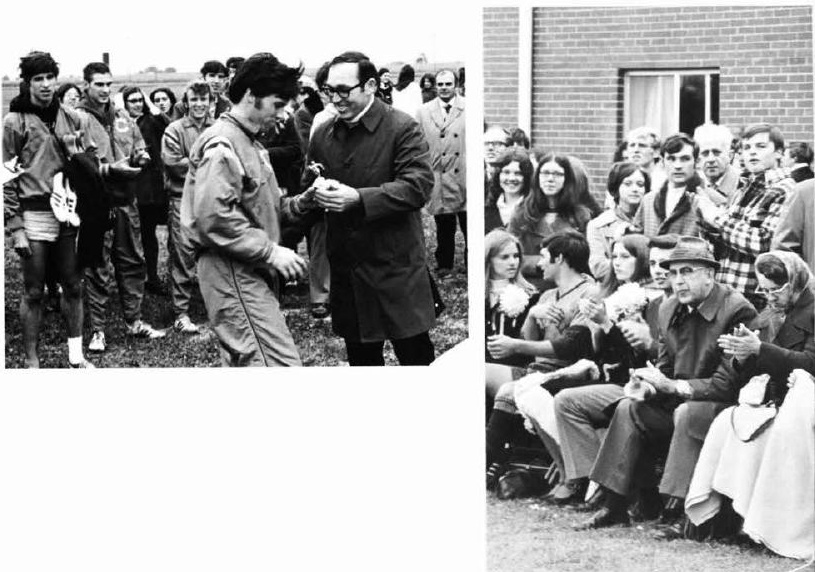


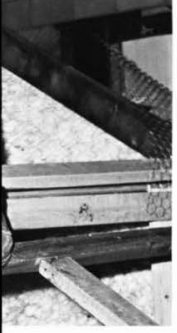

\section{homecoming}
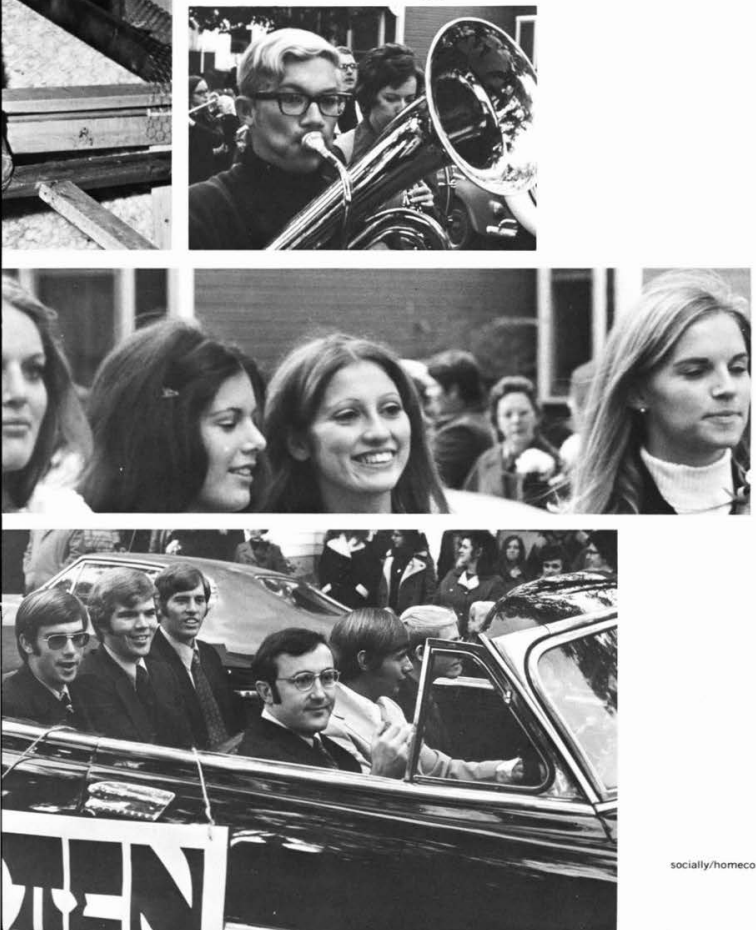

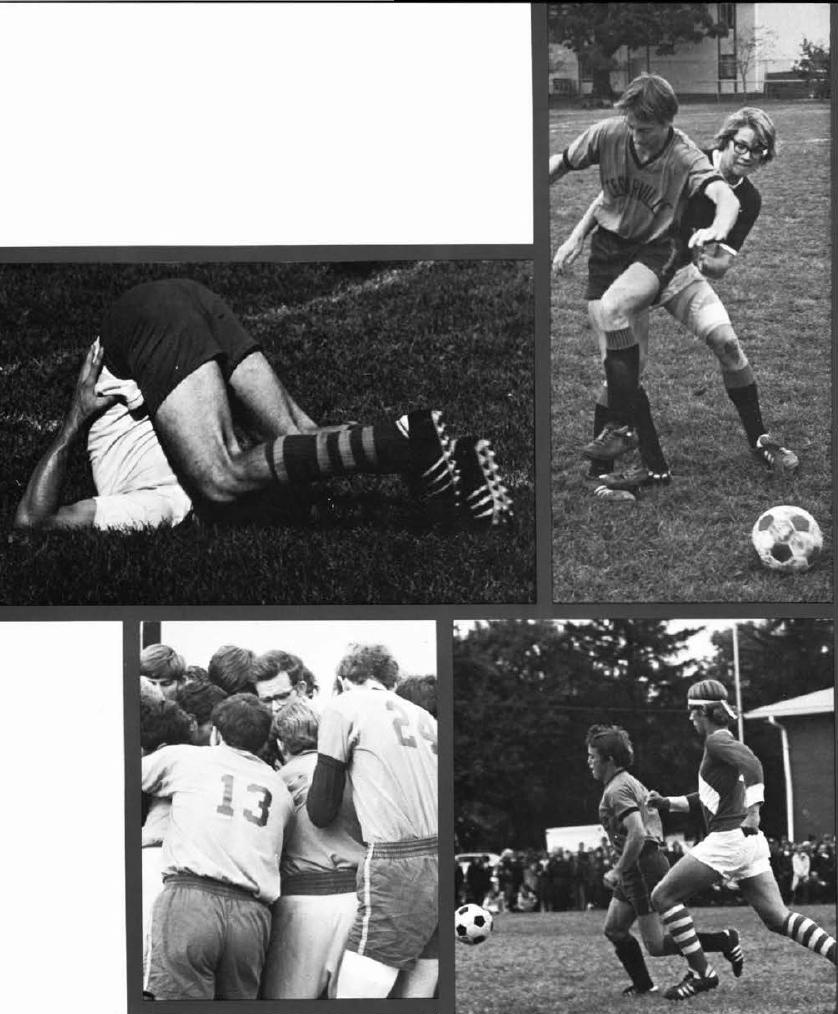

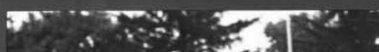
$i=5$ in ;$\frac{10}{2}$ $r a x^{2}=$ ato

Nes: 

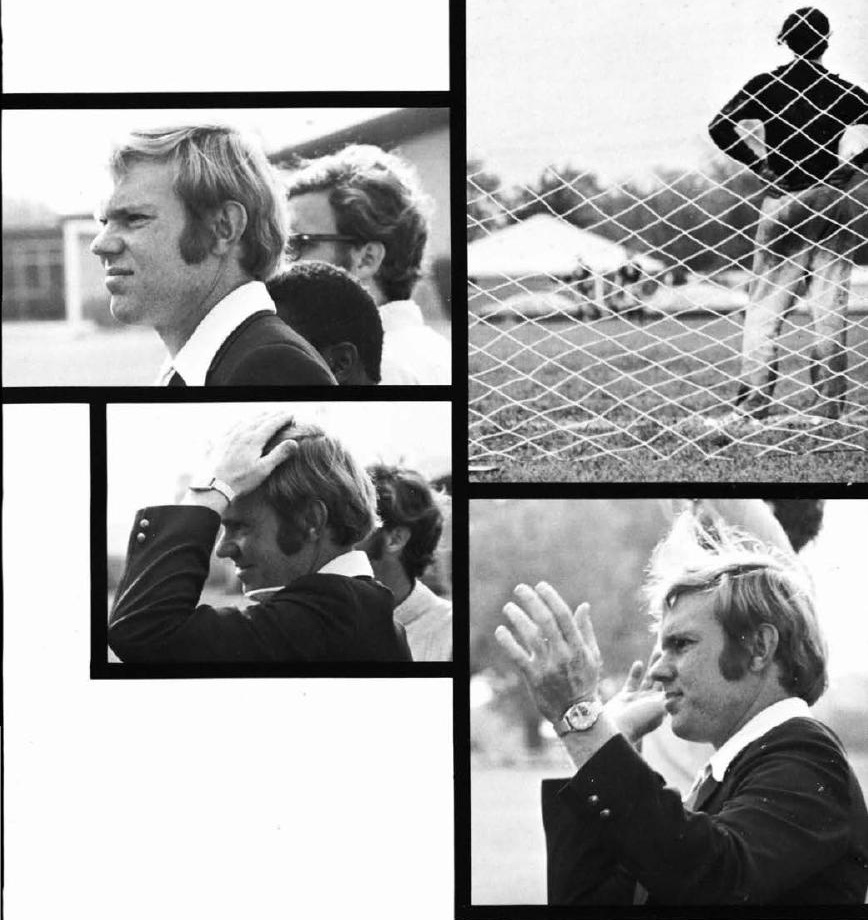

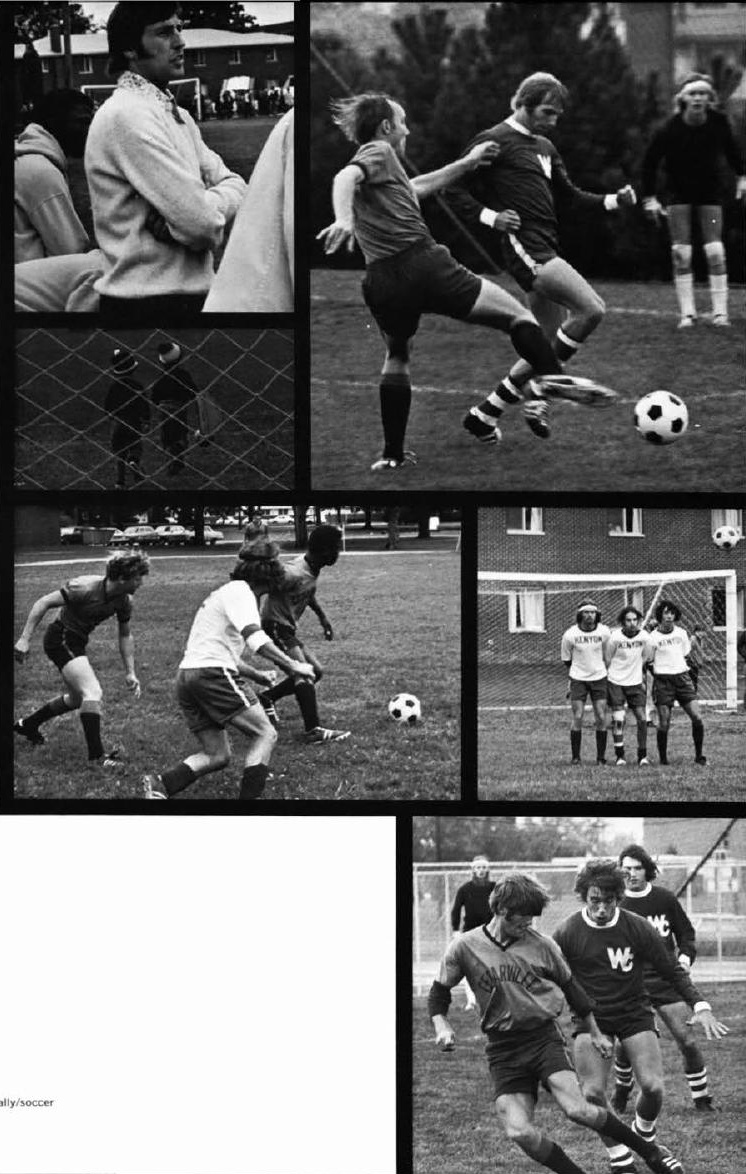


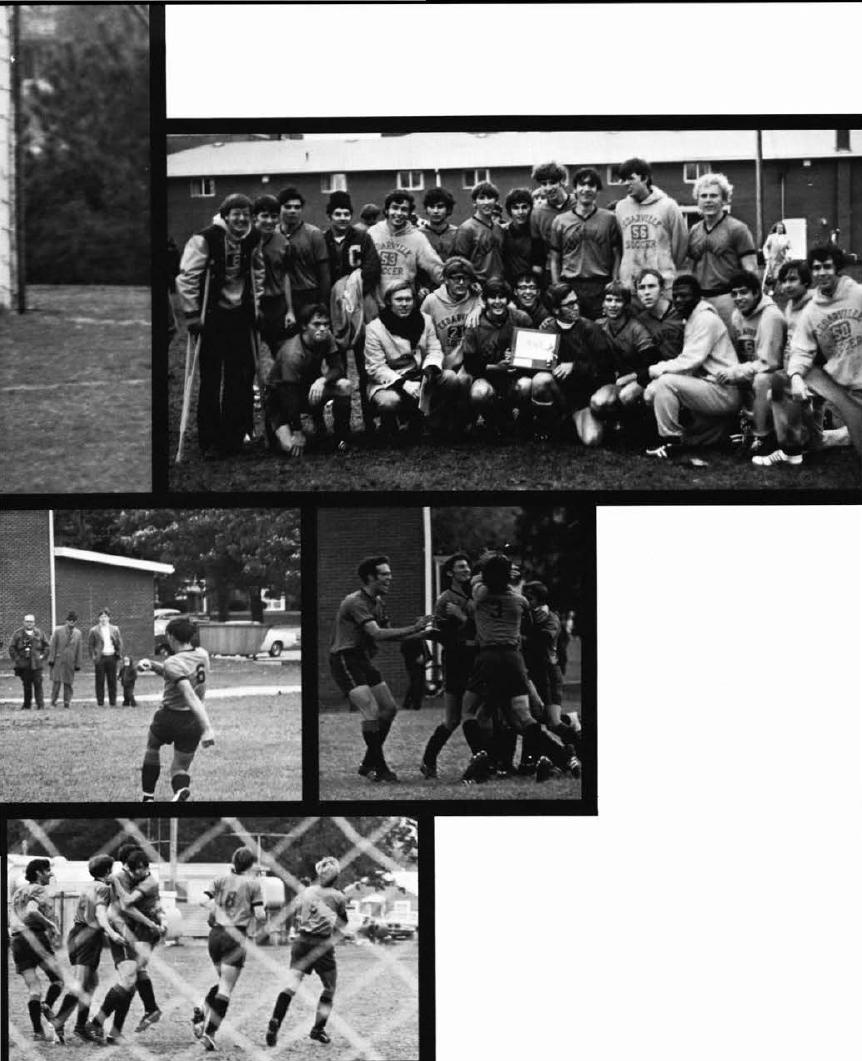



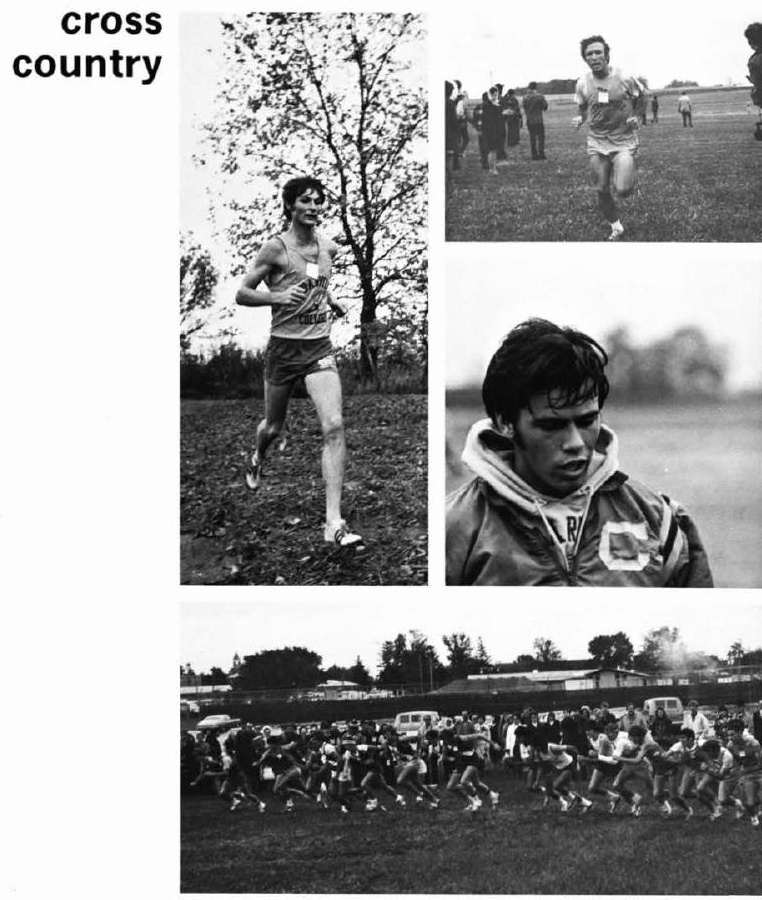

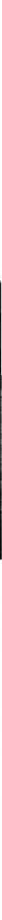

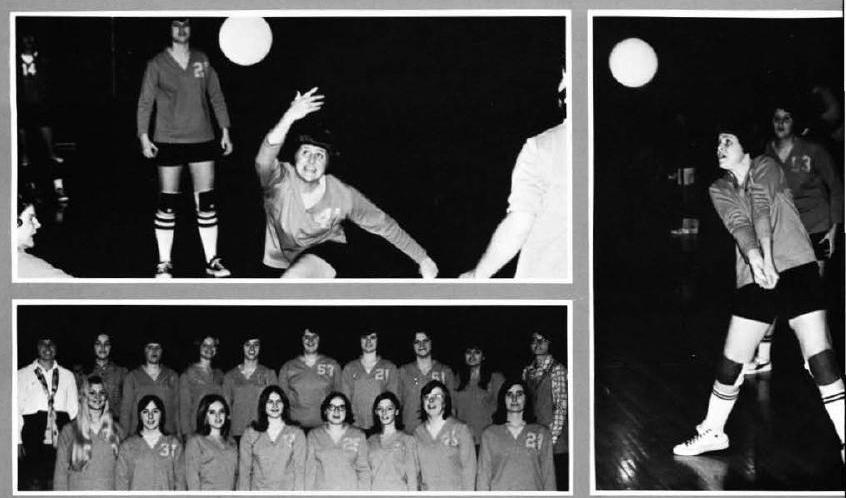

H. o para
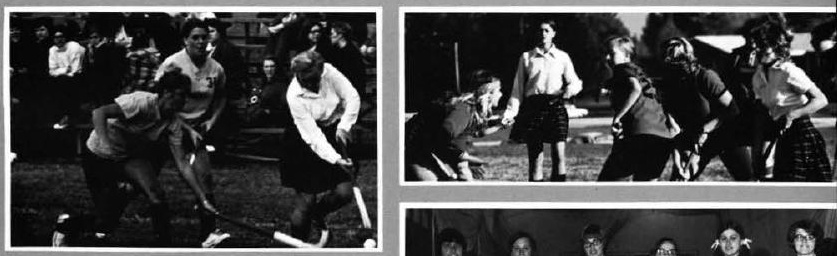

field

hockey

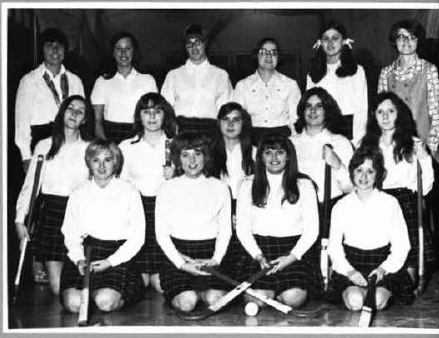




\section{fall bible conference}

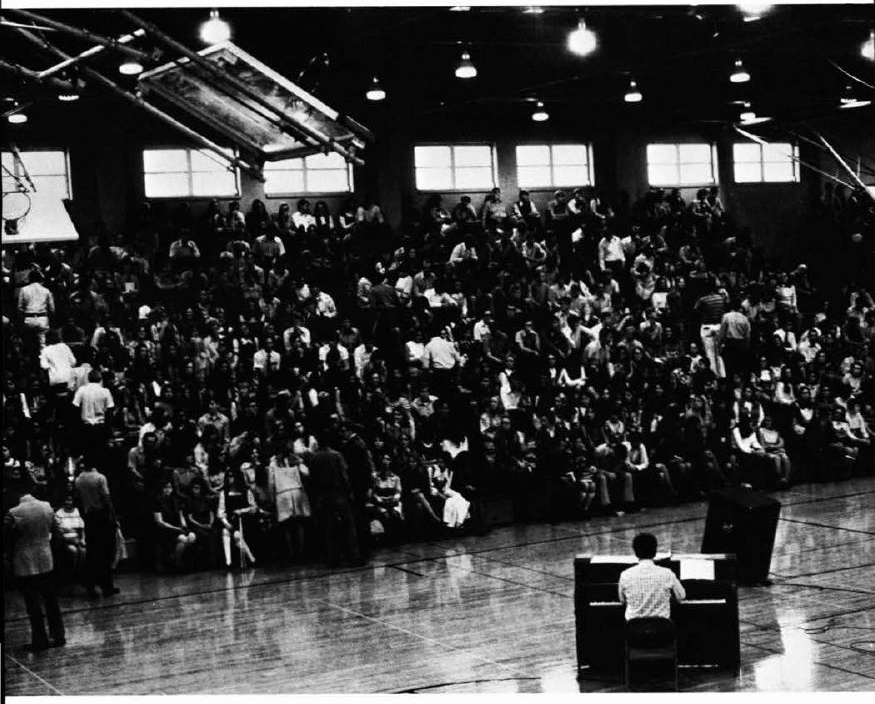




\section{christian service}

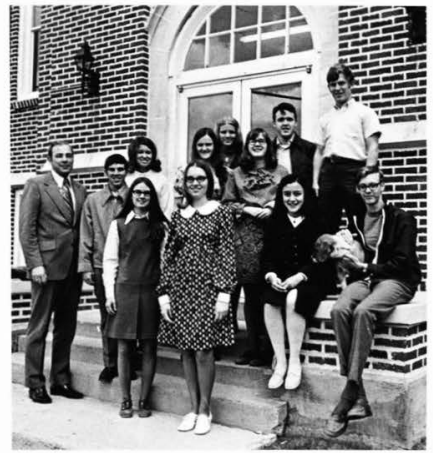

When someone reaches out spiritually they are genuinely concerned. At Cedarville every student is given this opportunity through the Christian Service Dept.

Over sixty percent of the student body voluntarily become involved in activities relating to Christian service. These activities range from work in detention homes to services in local rest homes.

\section{jail service}

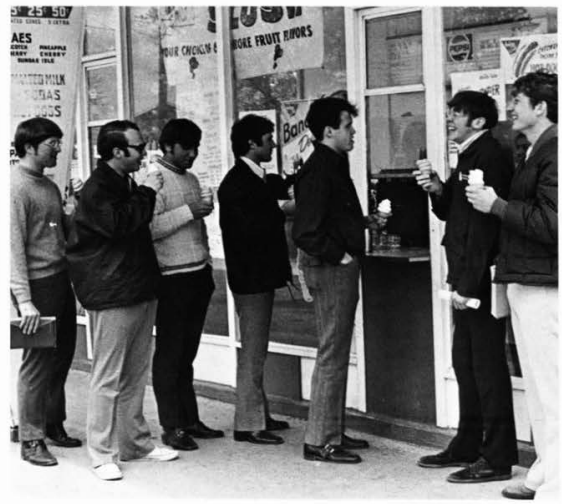



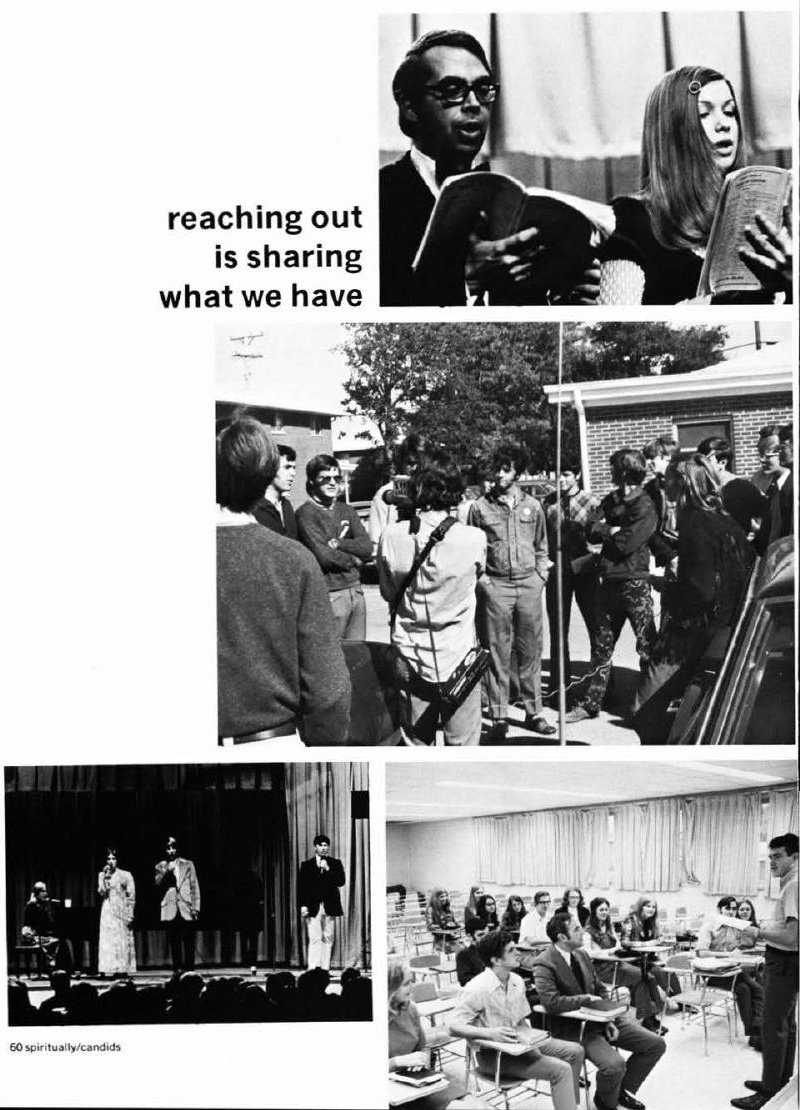


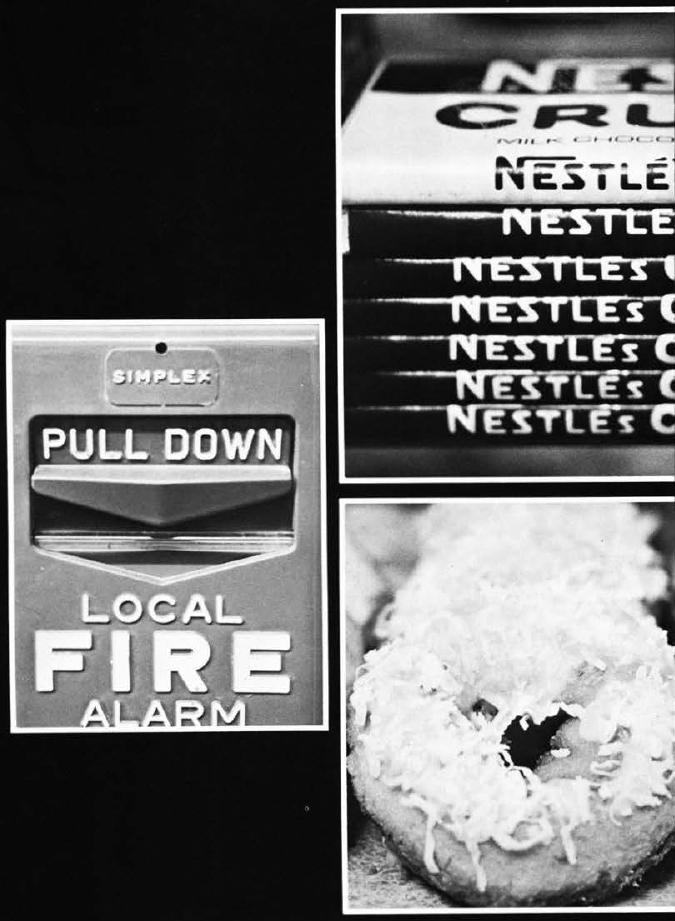




\section{드르.}

$-2$

GRUNCH -

RUNGM

RUNGH

RUNCH

RUNCH

रUNCA

\section{BOSB IE!}
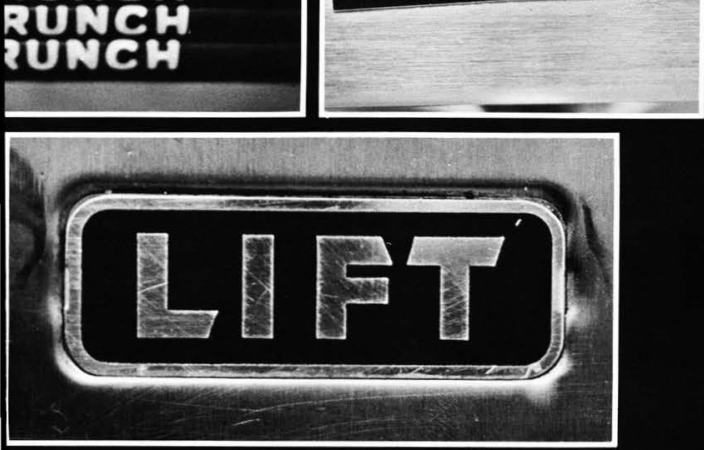

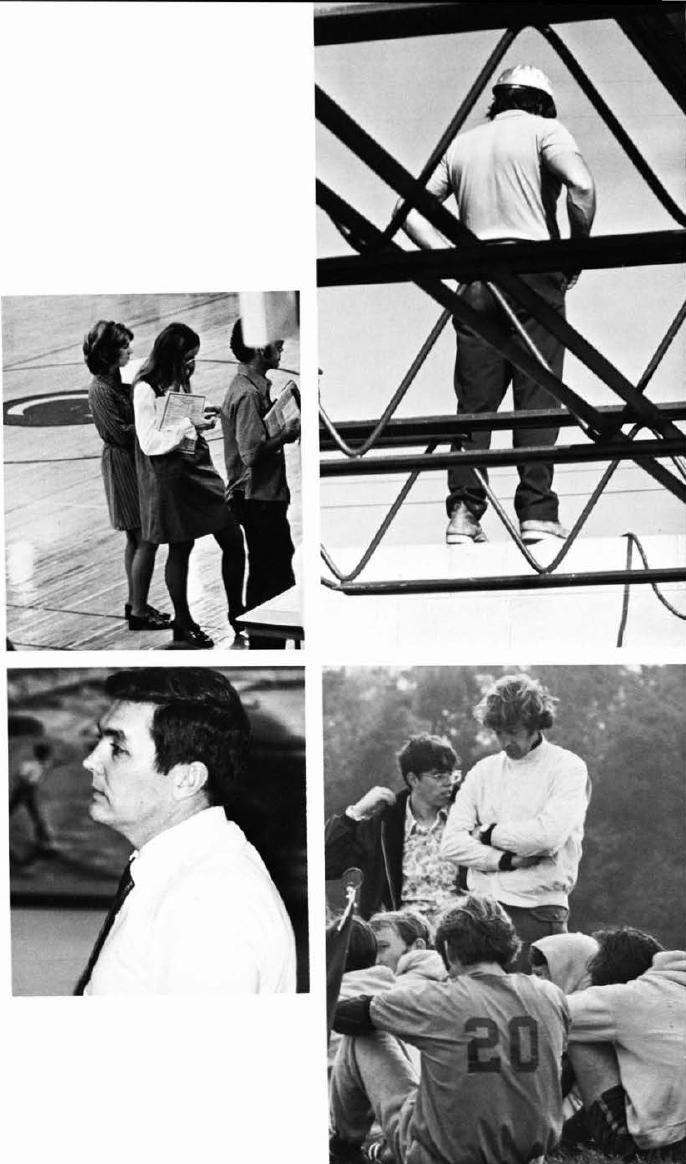


\section{winter is ...}
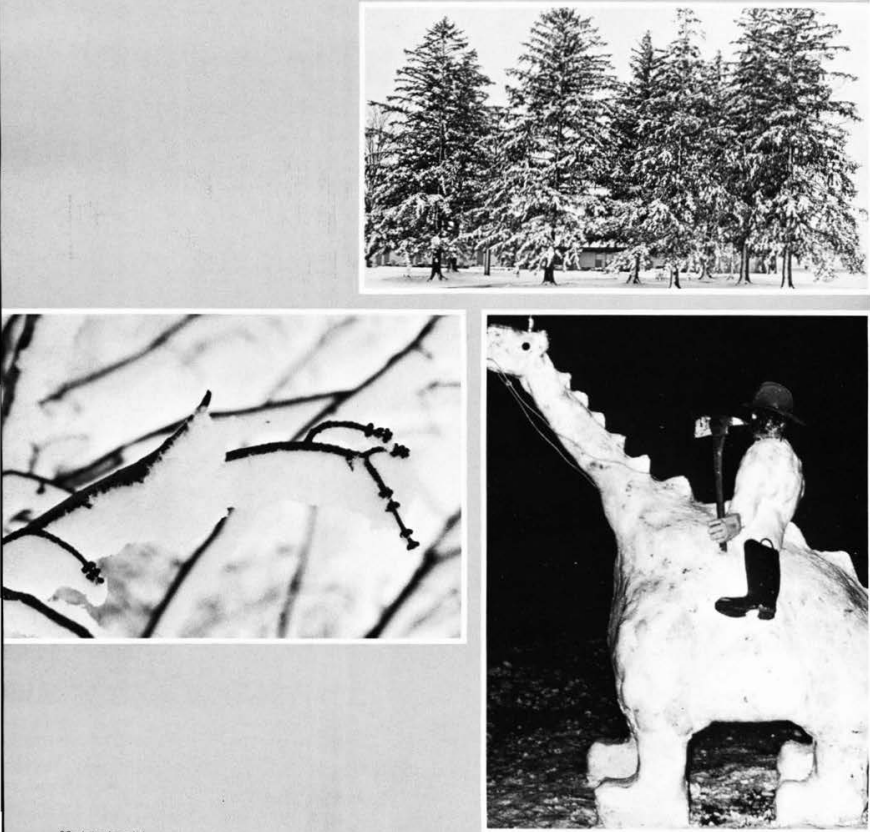


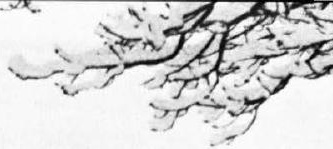

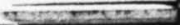

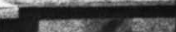

D.

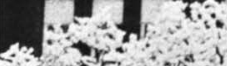

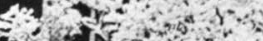

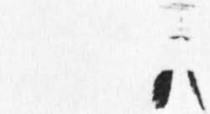

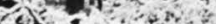

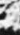
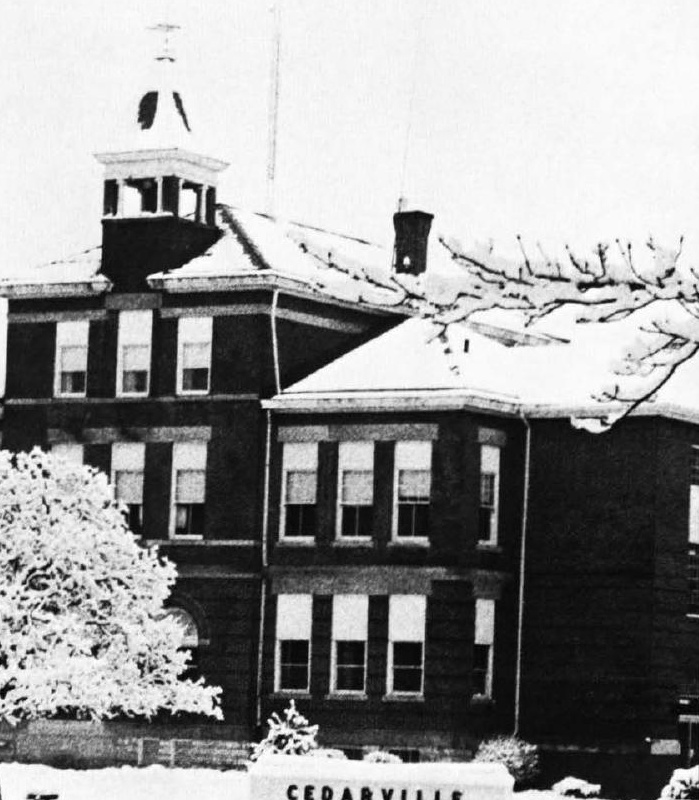

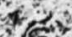

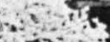

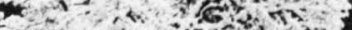

(E)

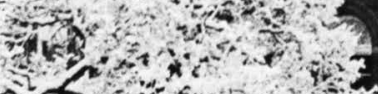

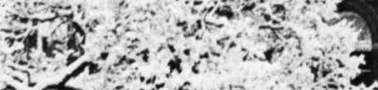

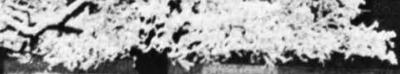

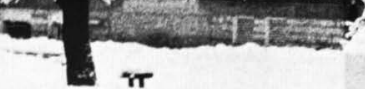

CEOAR VILLE COLLEGE

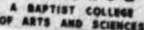

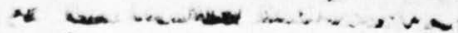
9

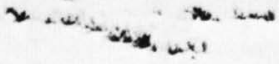



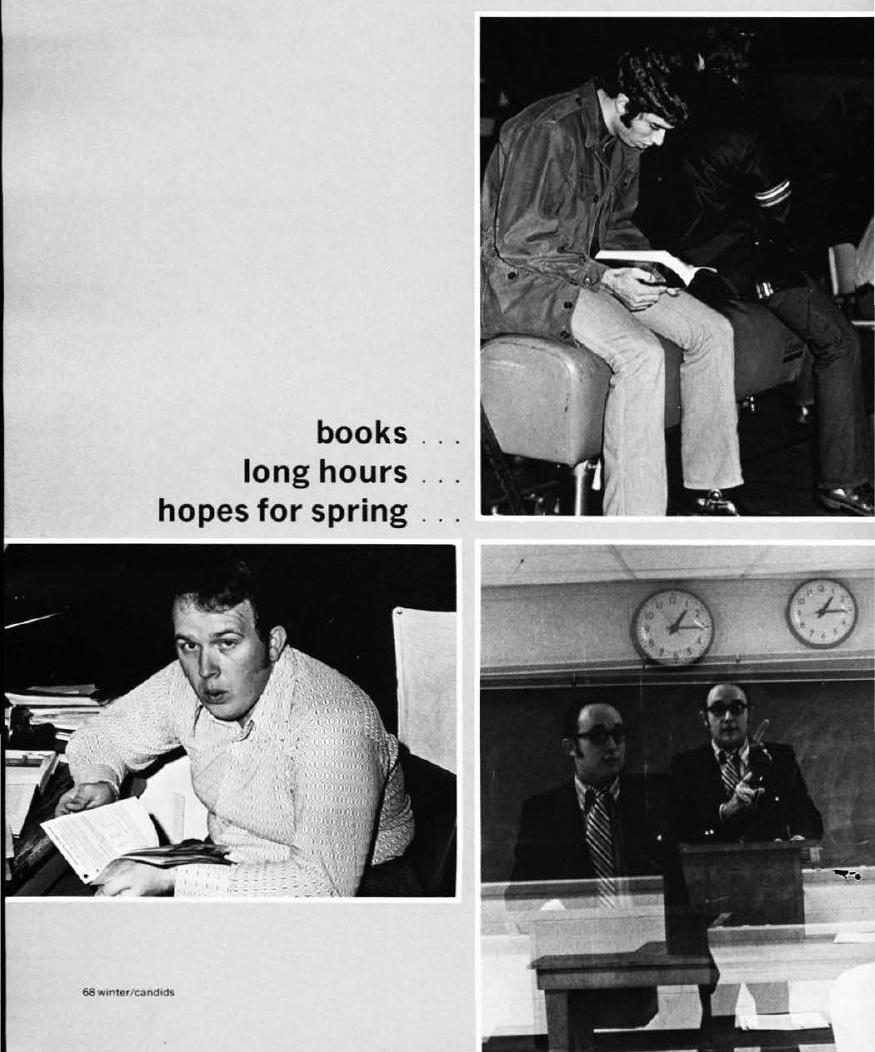


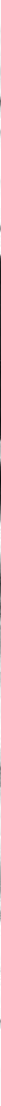



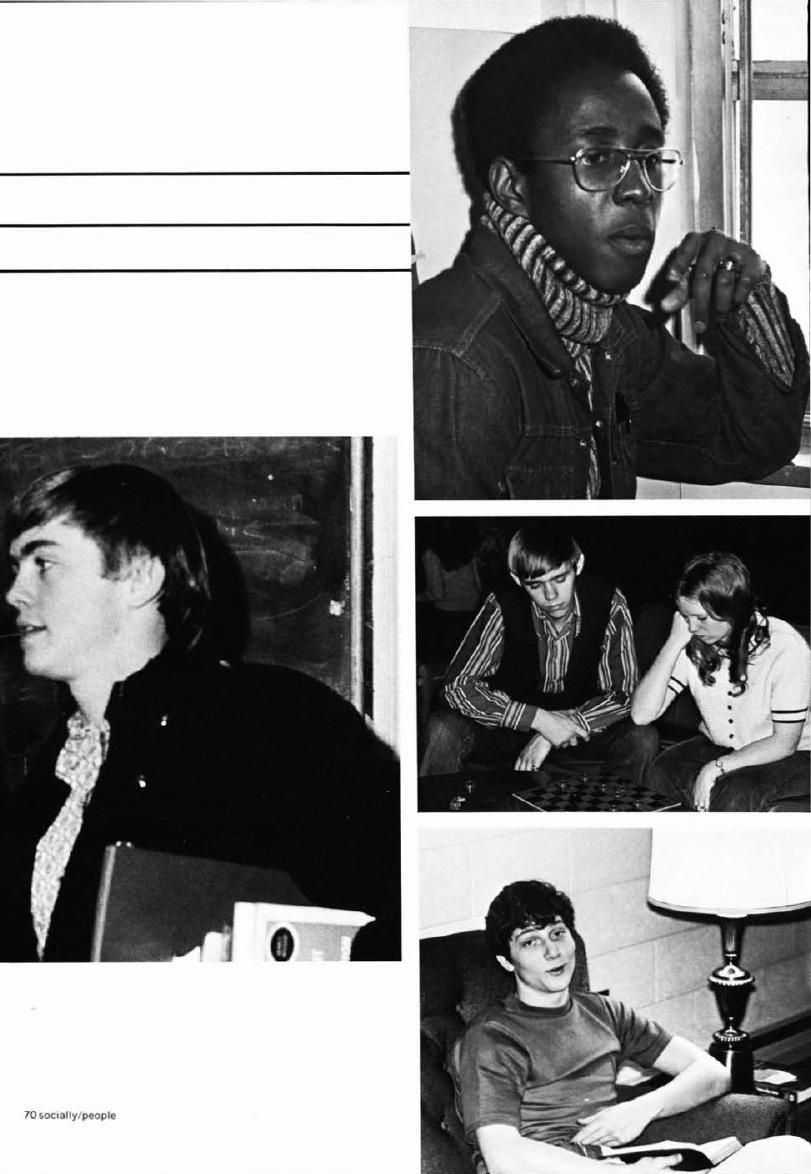

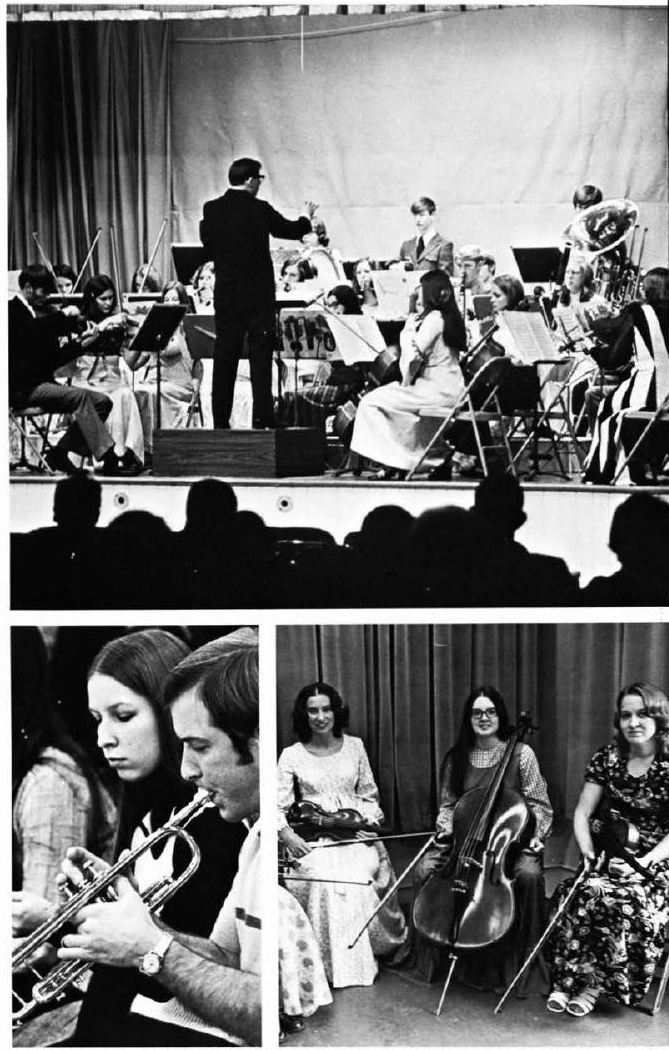


\section{orchestra and band}
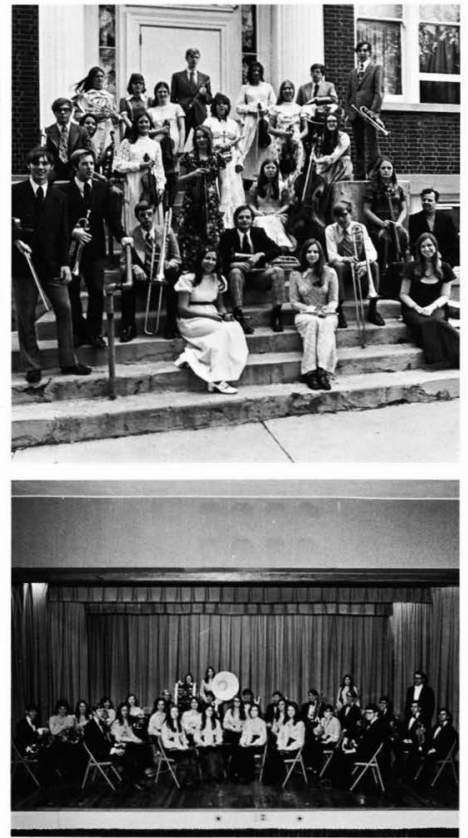


\section{winter is ...}
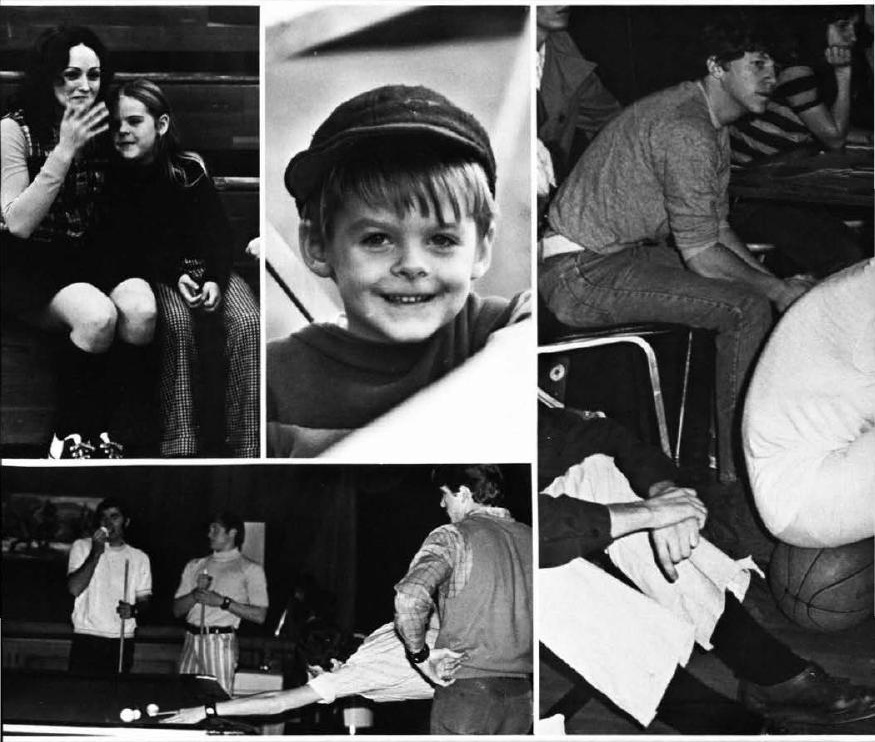


\section{maybe a little bit of everything}

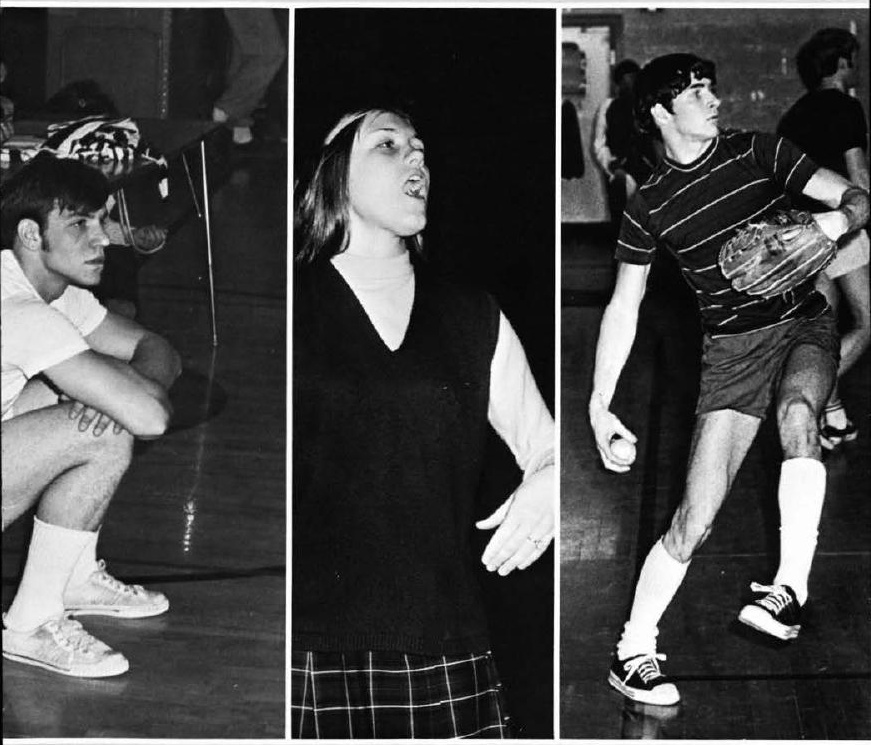




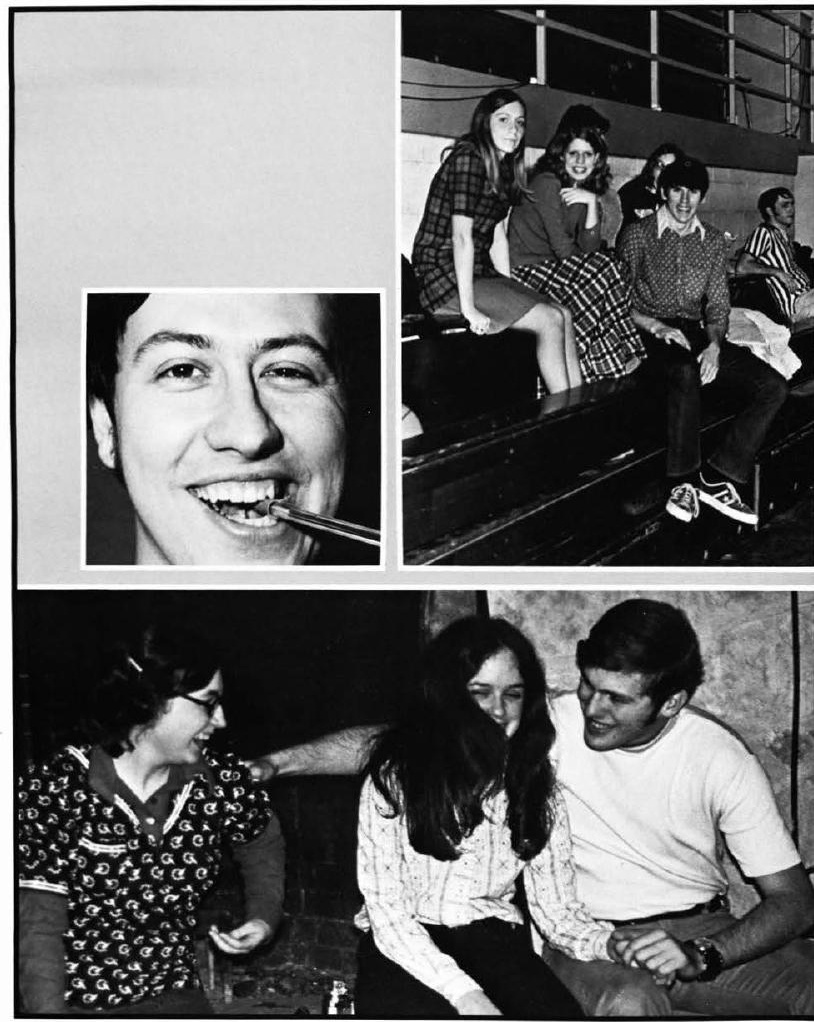



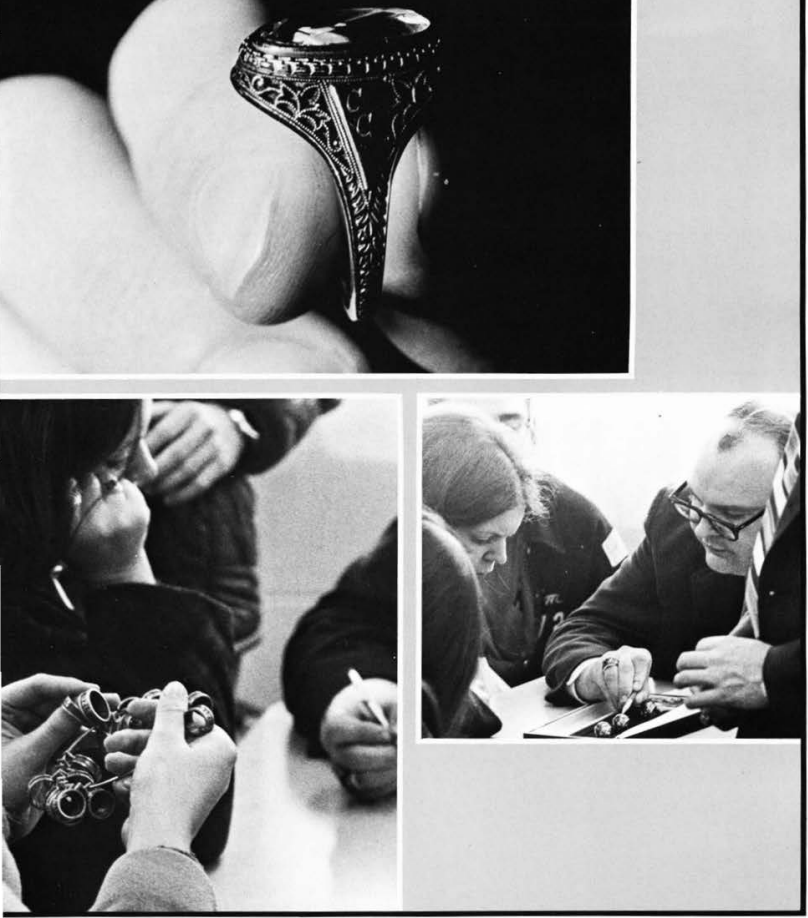


\section{but sometimes not much of anything!}
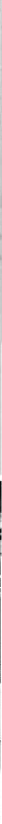

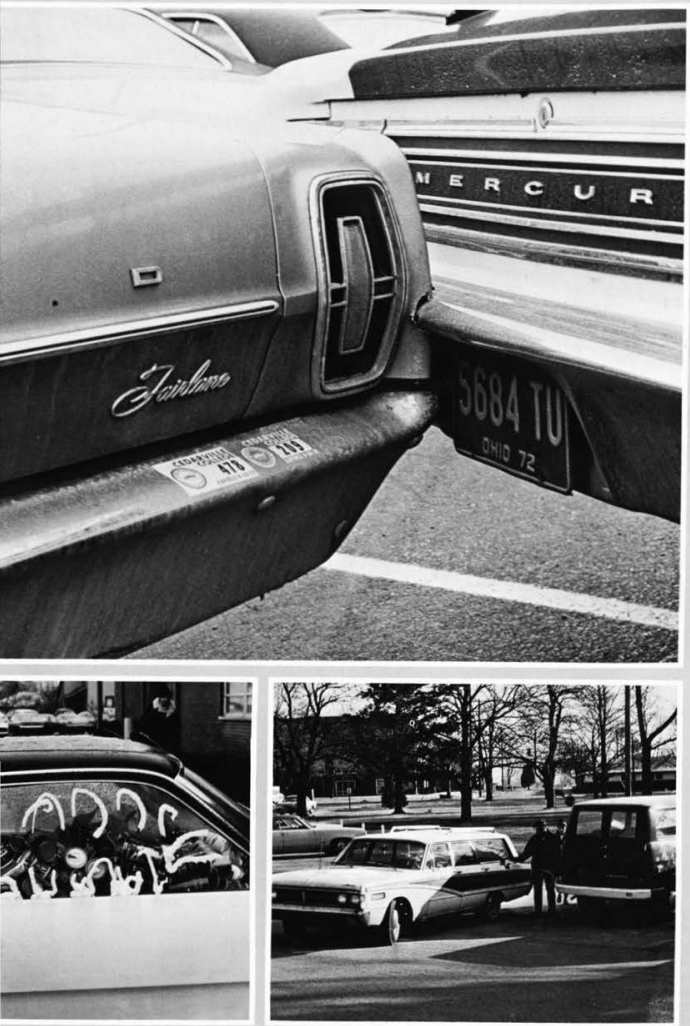

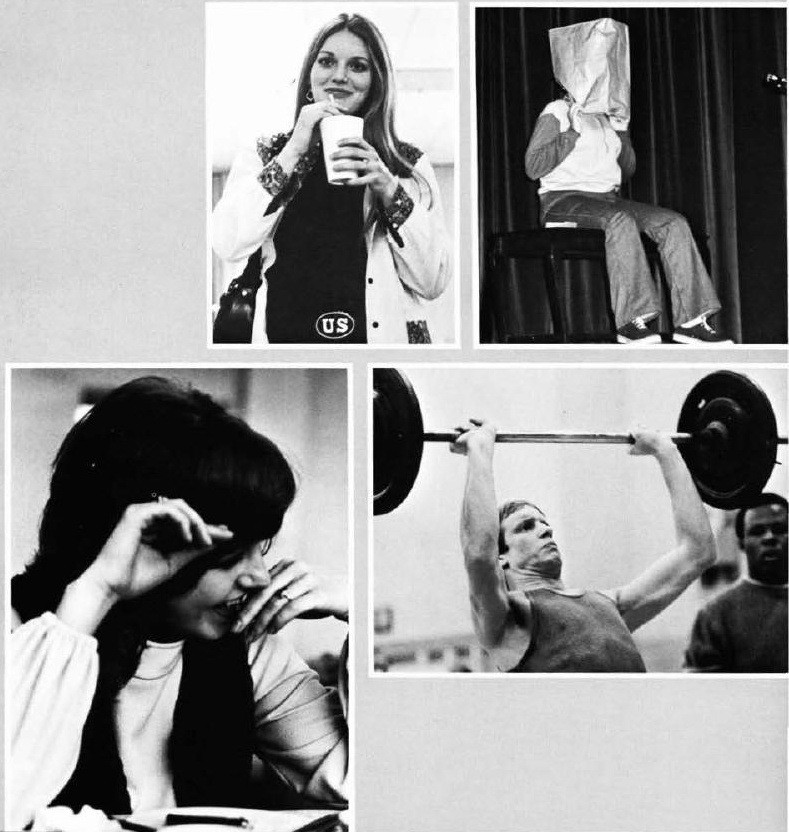

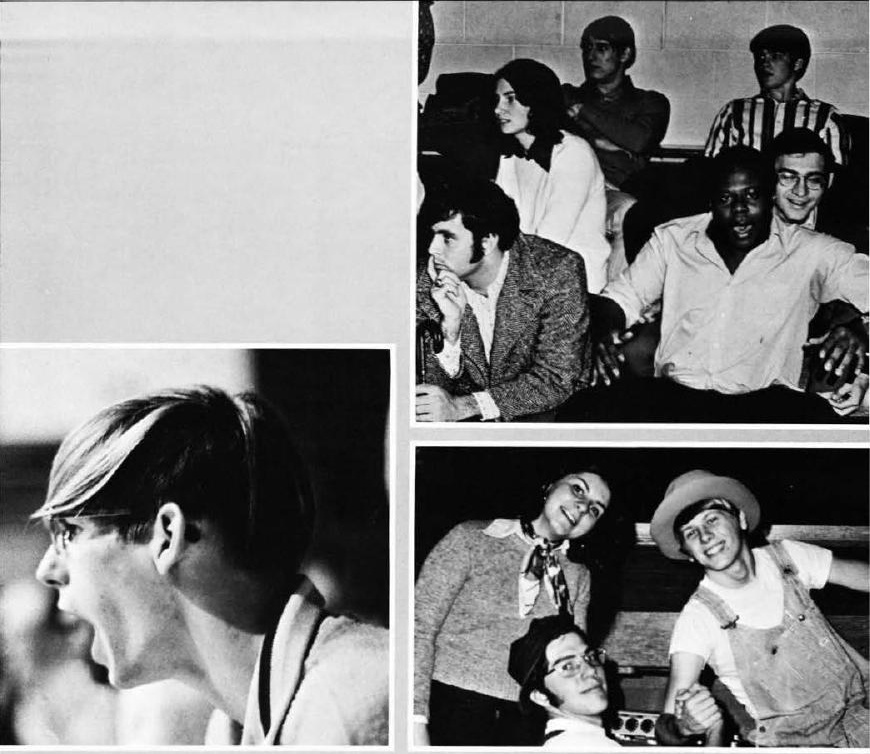

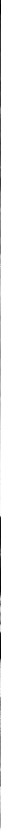


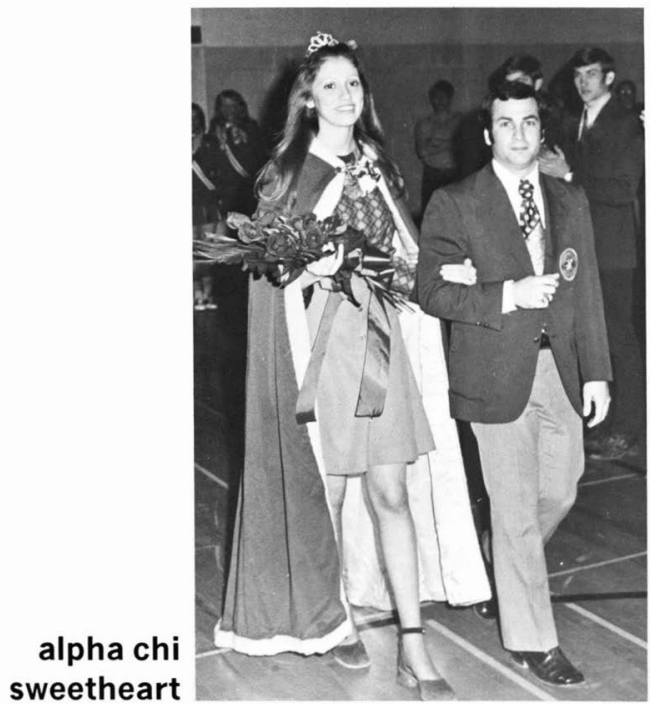

Annually the men of Alpha Chi select one girl of Cedarville College to reign as their Sweetheart. This year's Sweetheart is Miss Georgeanna Axiotis. She was crowned by last year's Sweetheart. Miss Becky Williams.

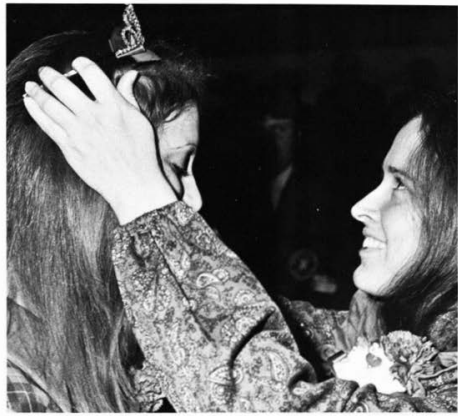




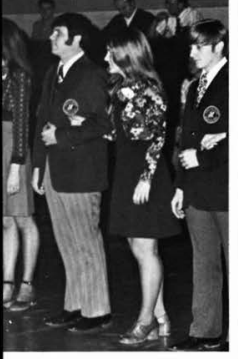



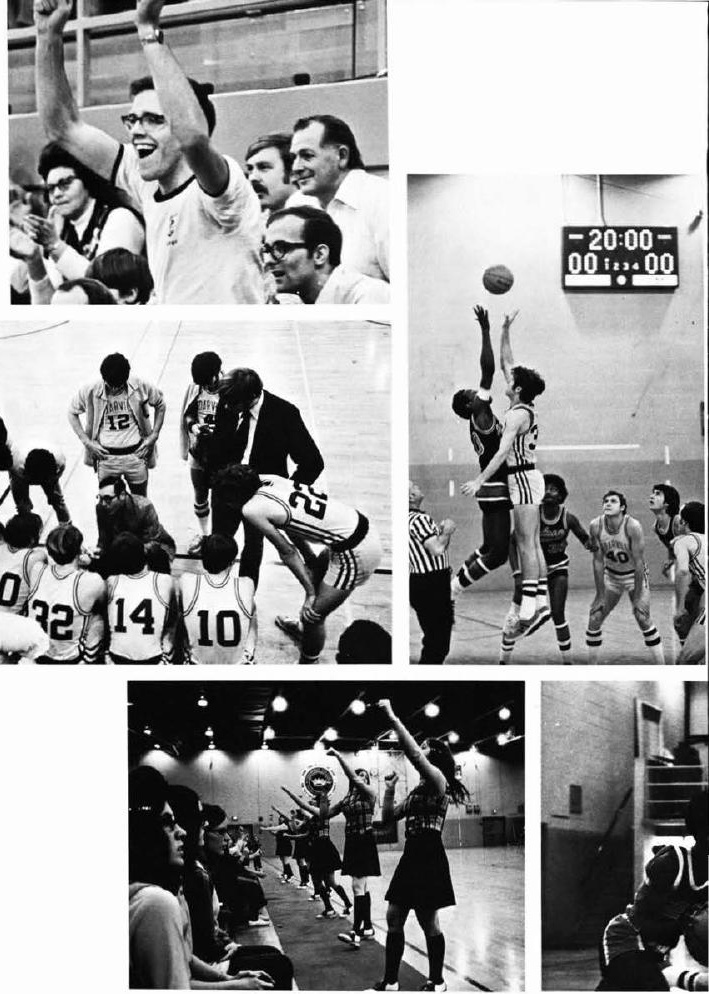


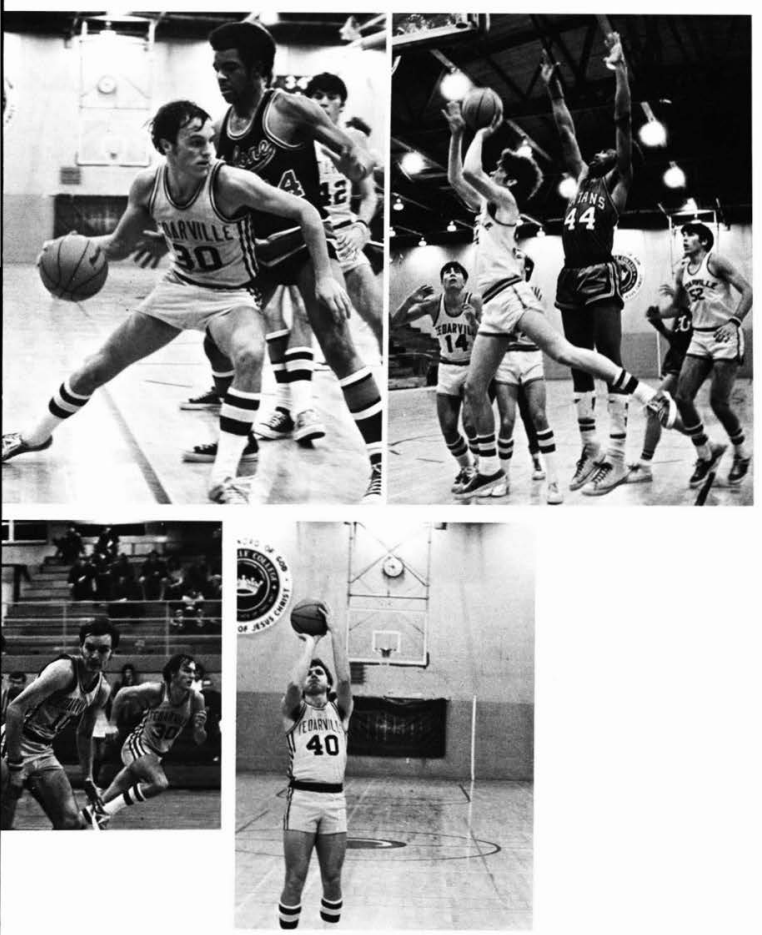




\section{basketball ...'72-'73 season}
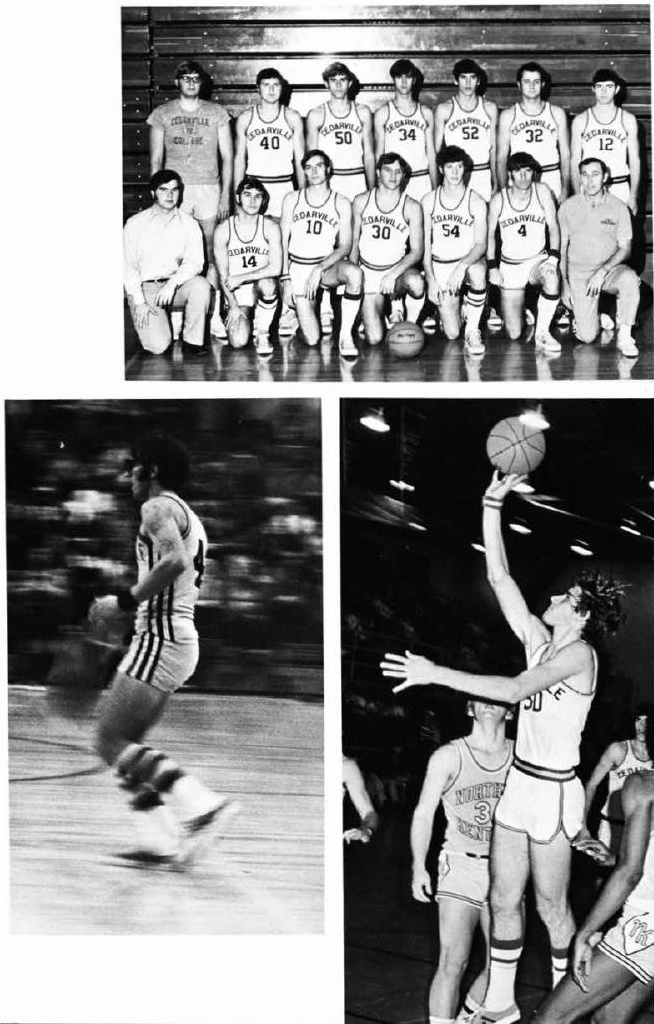

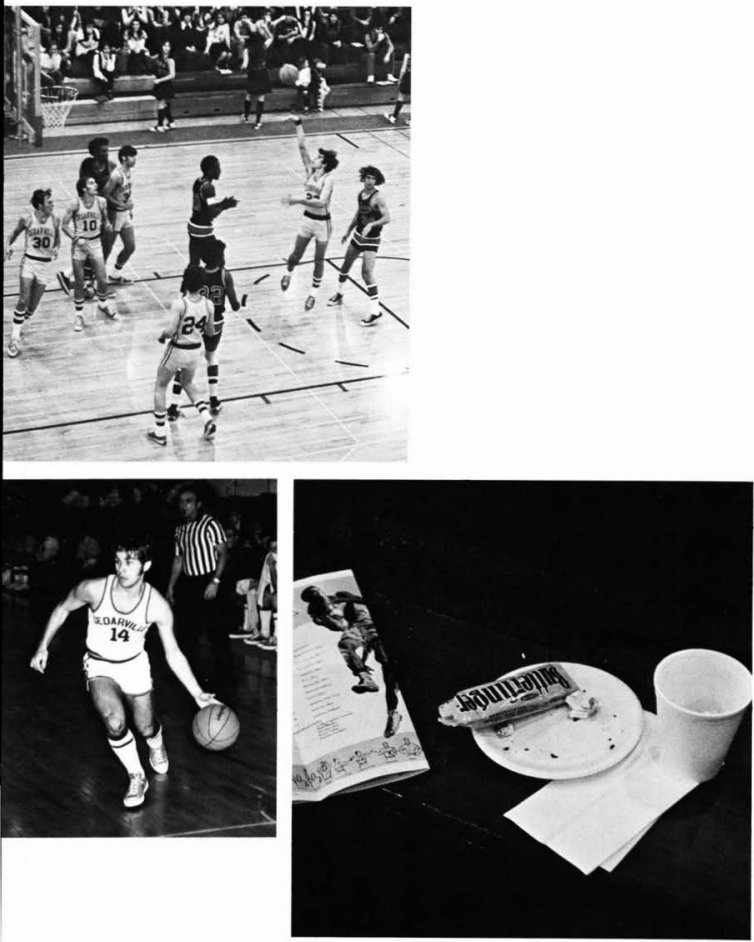


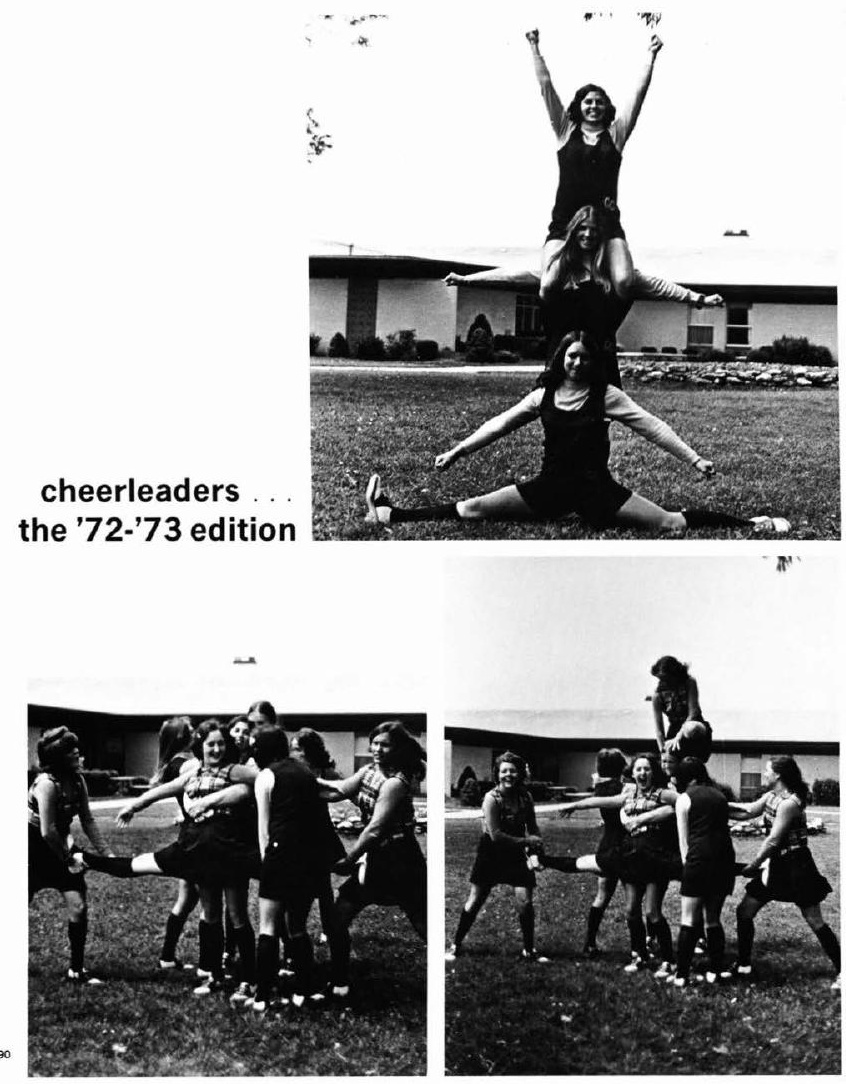




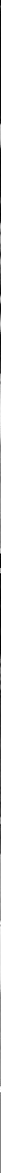



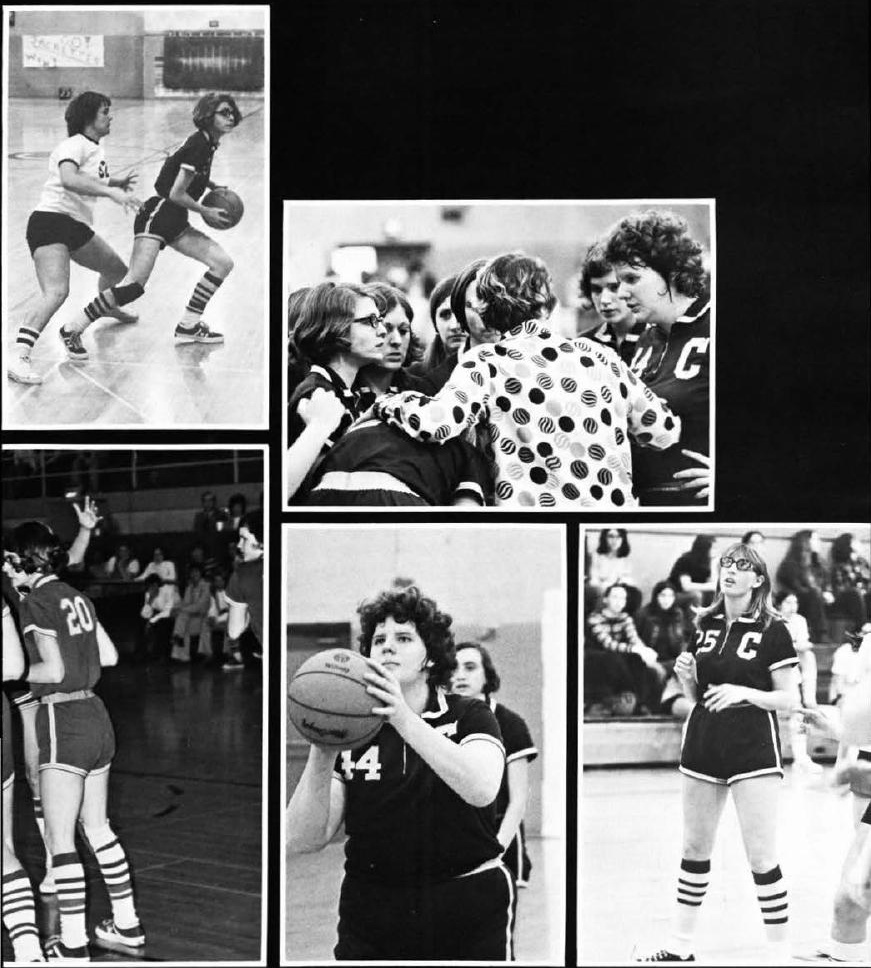
jackettes? ... the best around

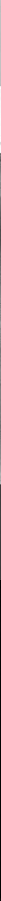




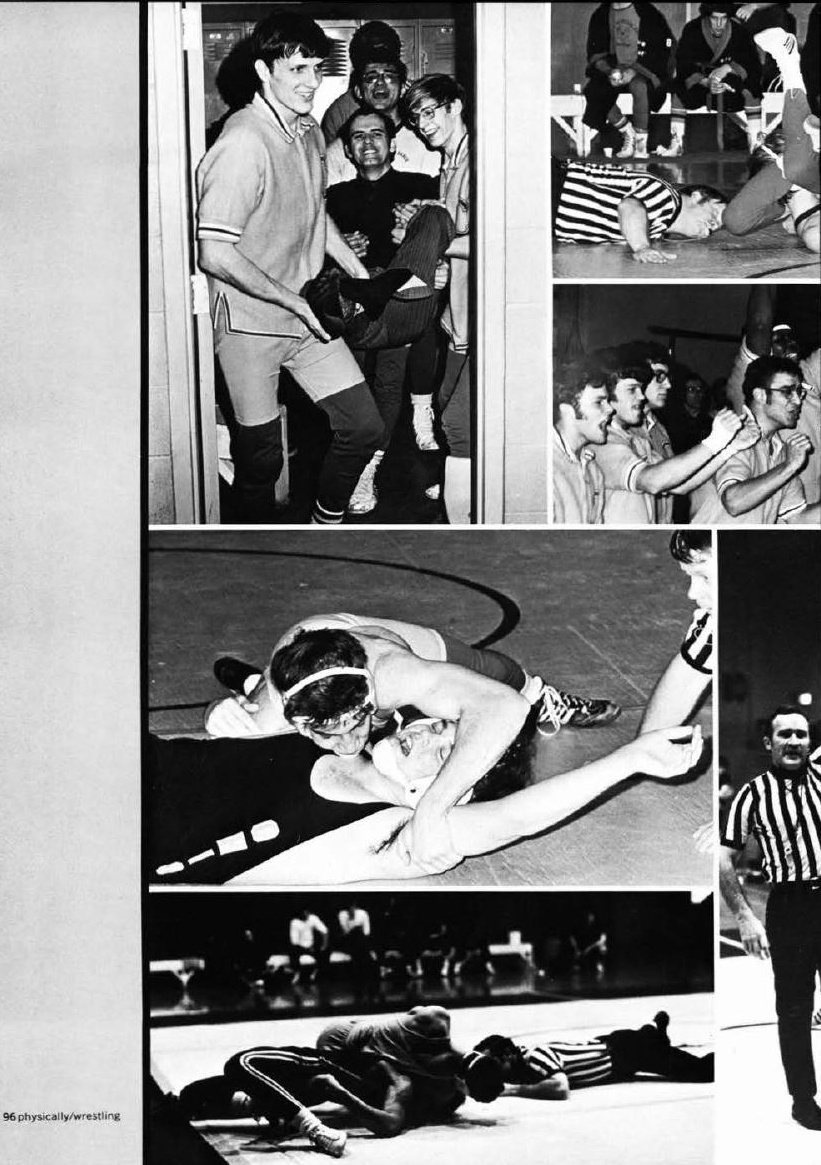




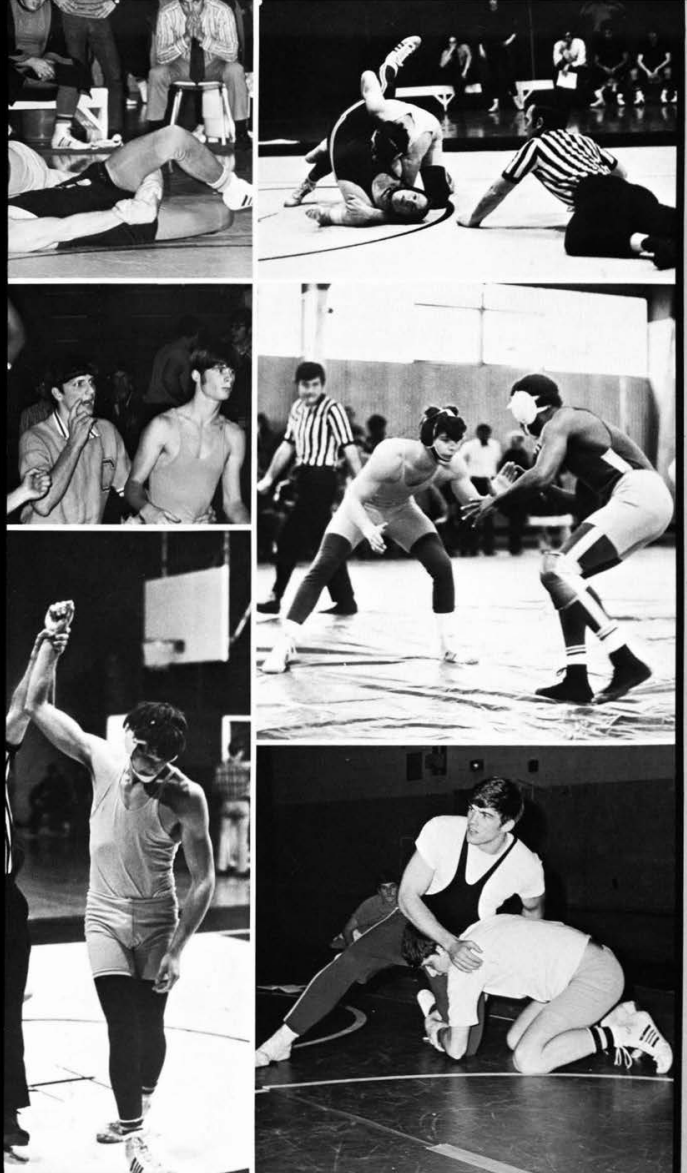




\section{you want my blood? gulp!!}
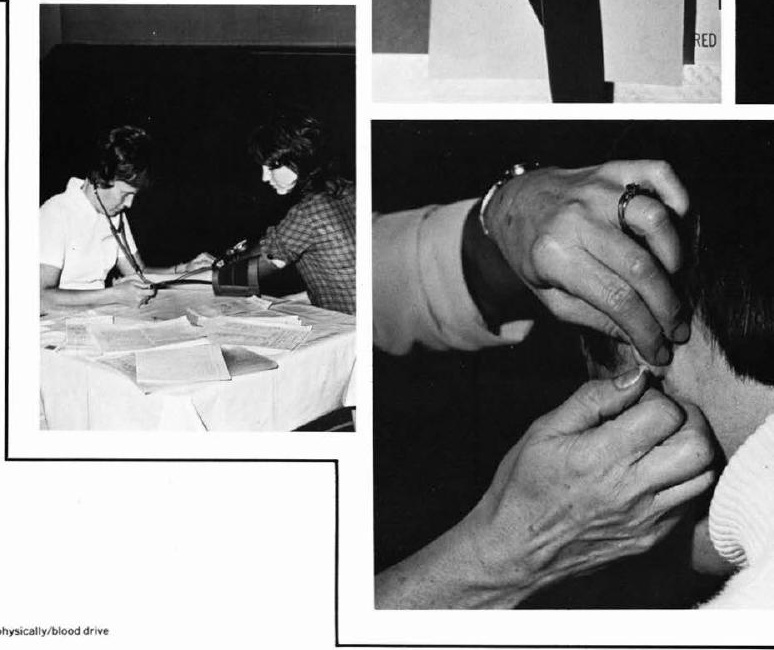


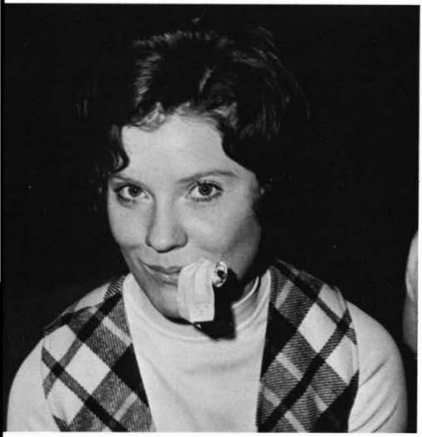



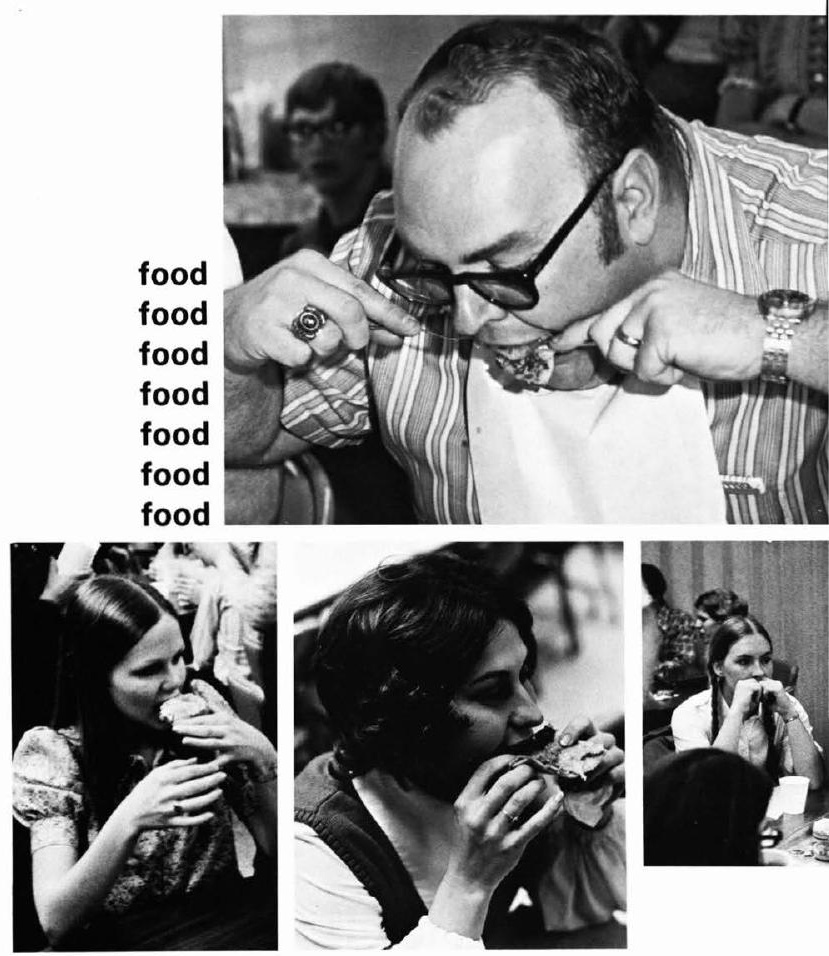


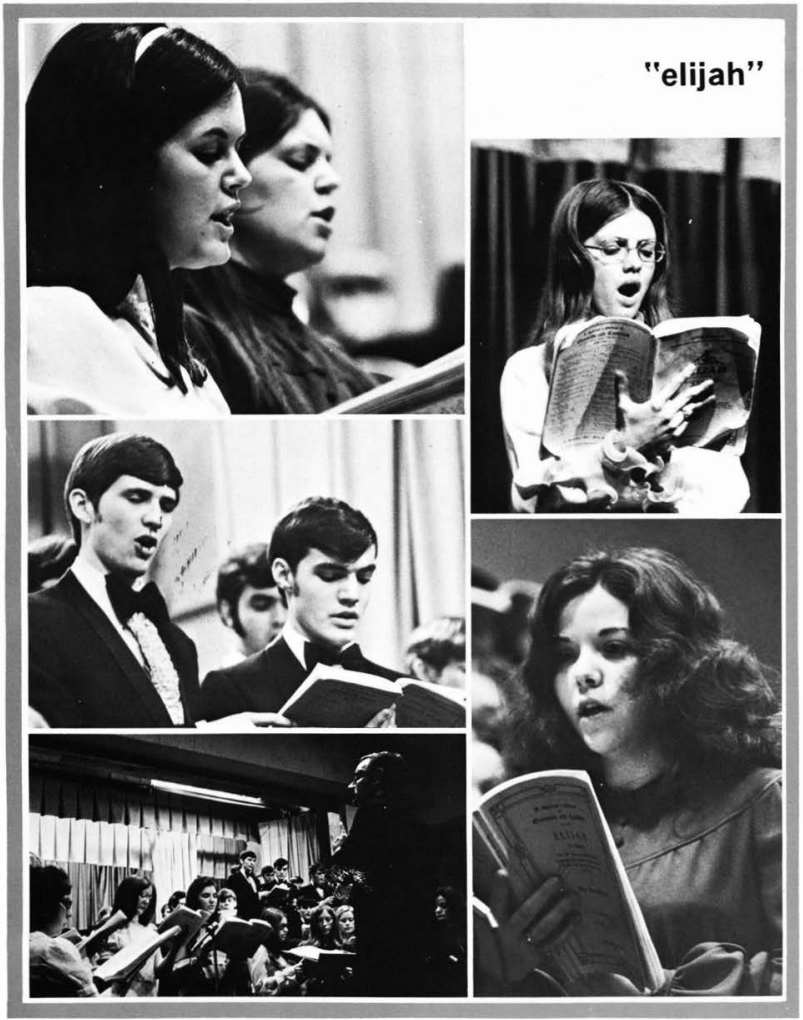

102 spiritually/"elijah" 


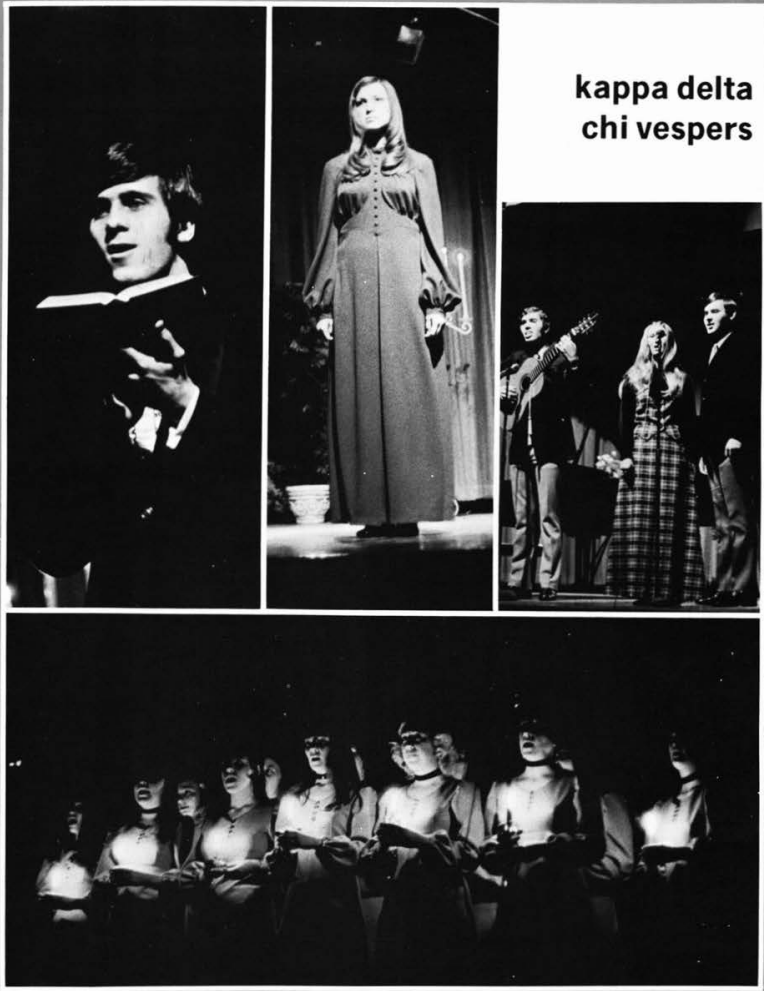




\section{detention homes}
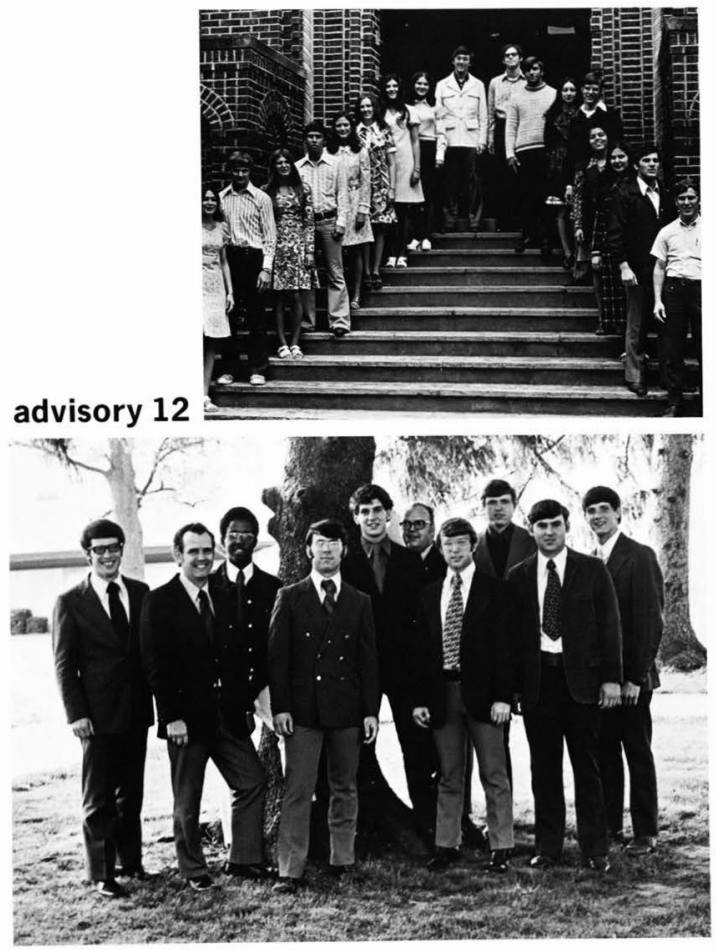


\section{education}

\section{GET A TASTE OF \\ EQUCATIOH}
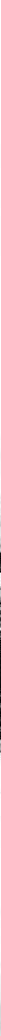


\section{just people ...}
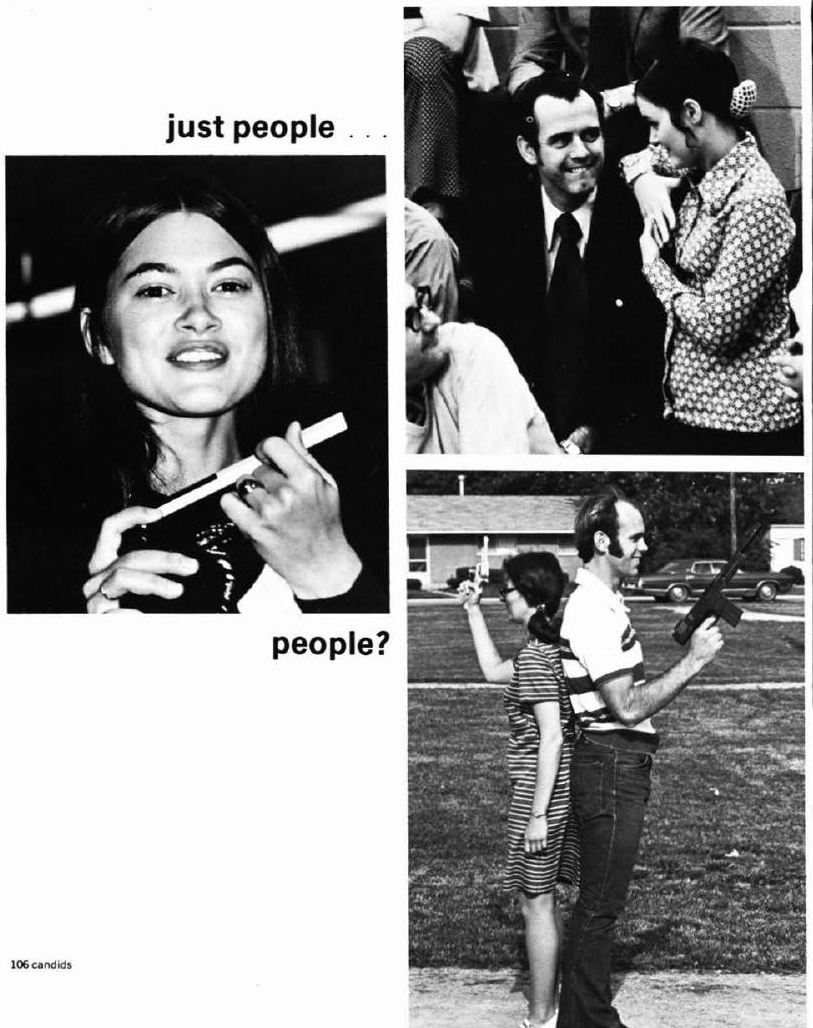


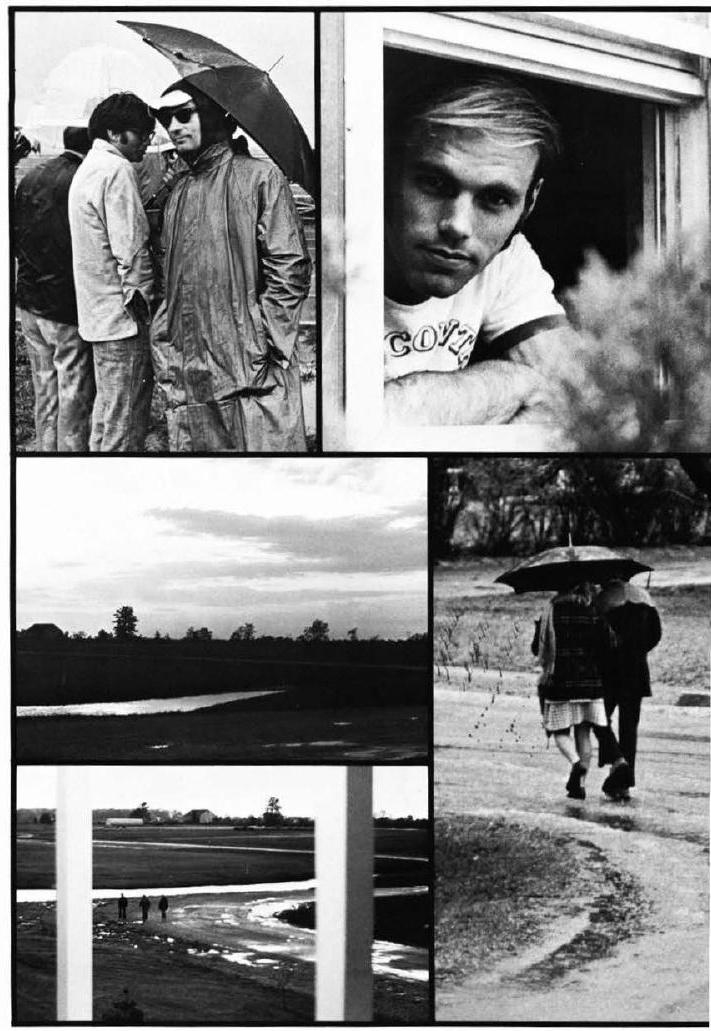




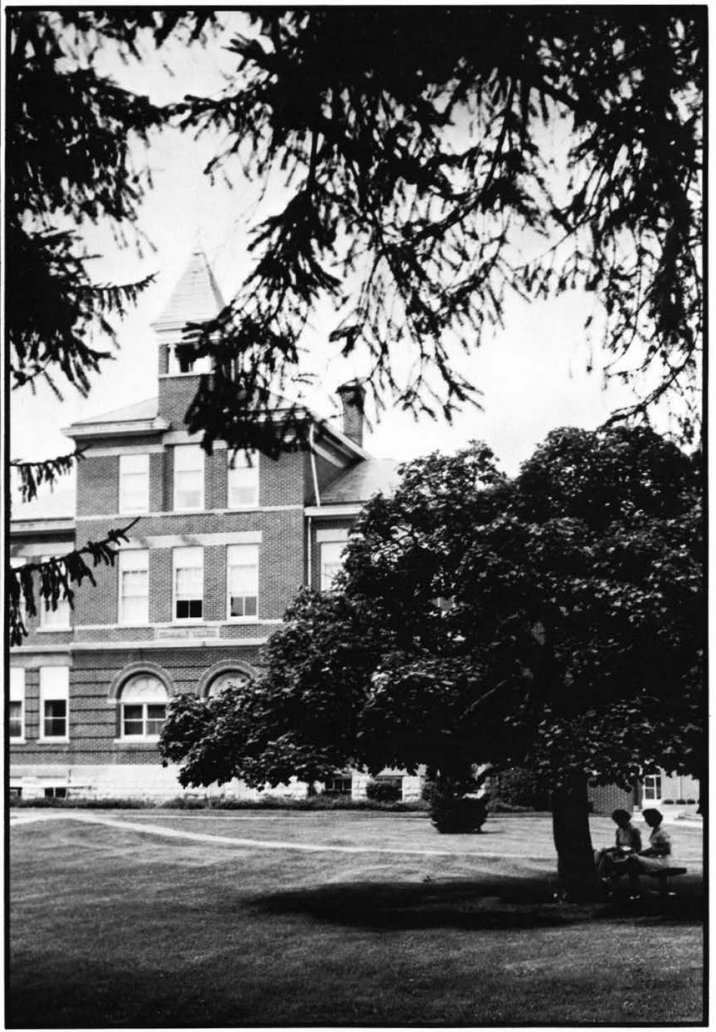




\section{cedarville spring ... water!}
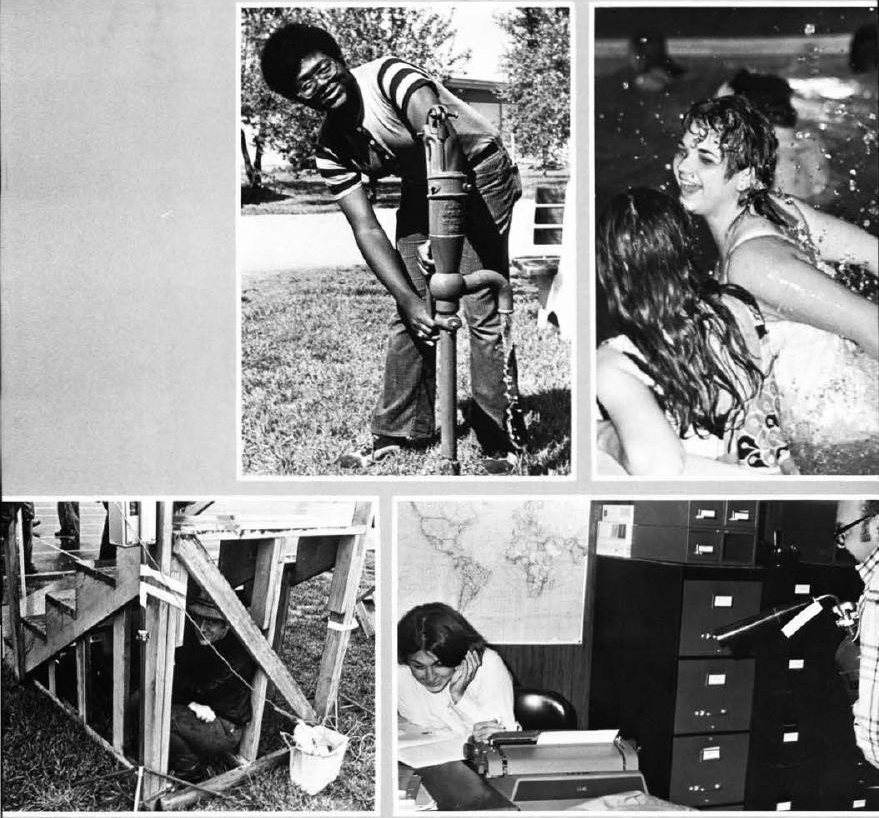

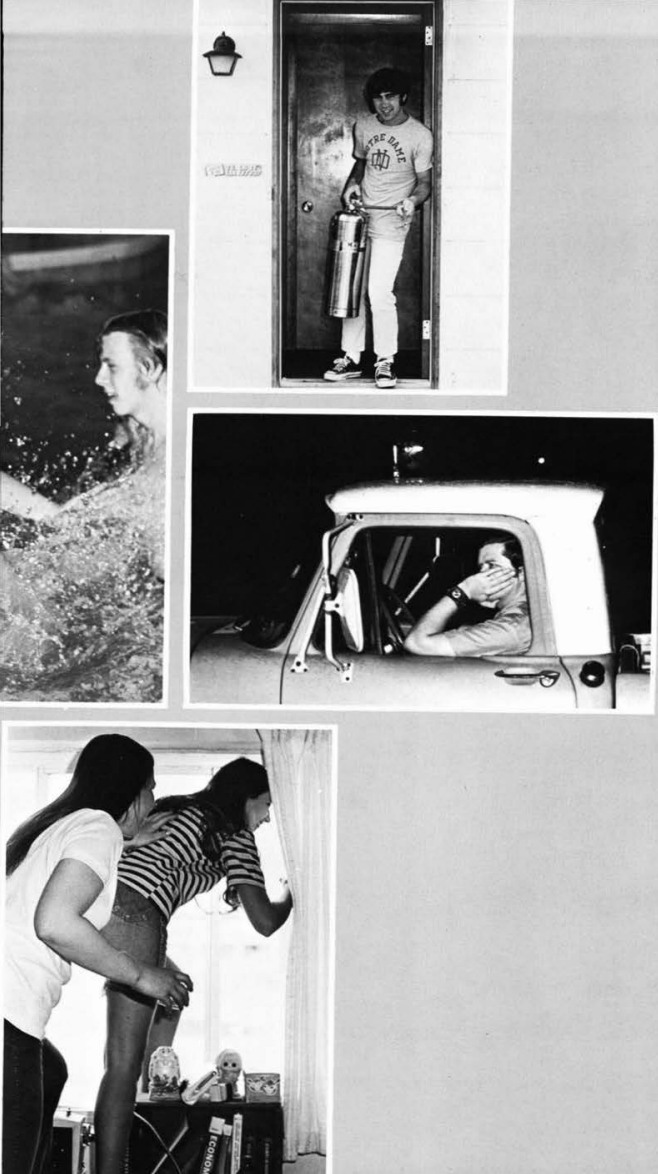

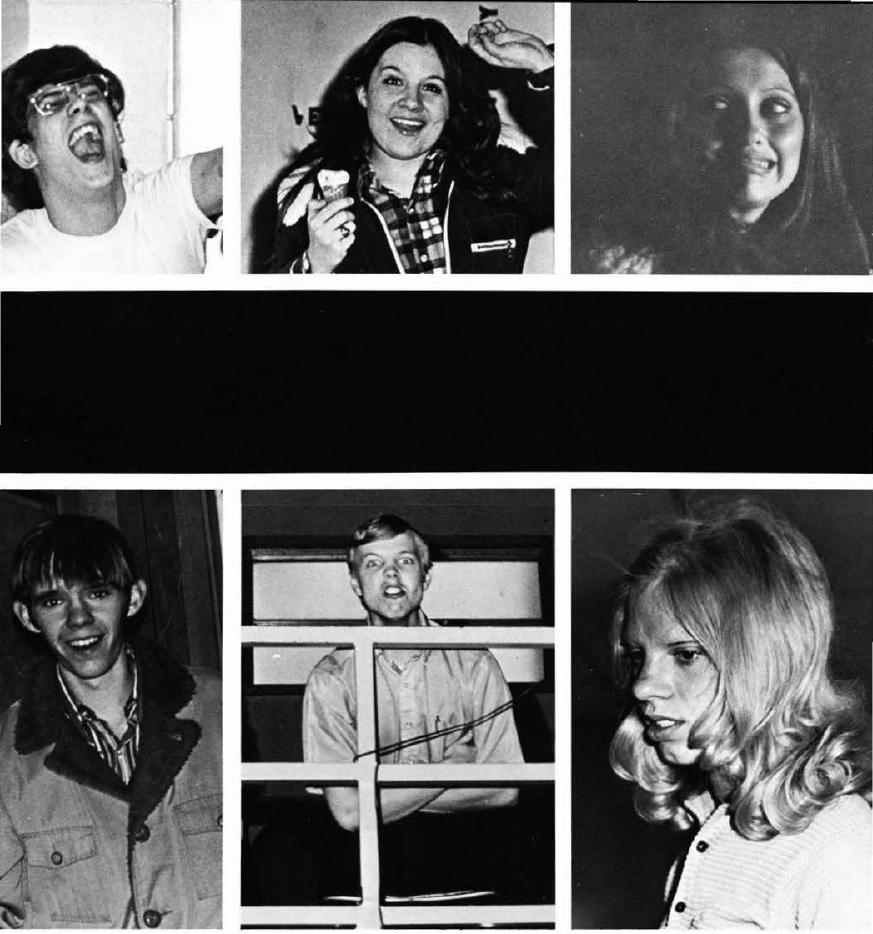

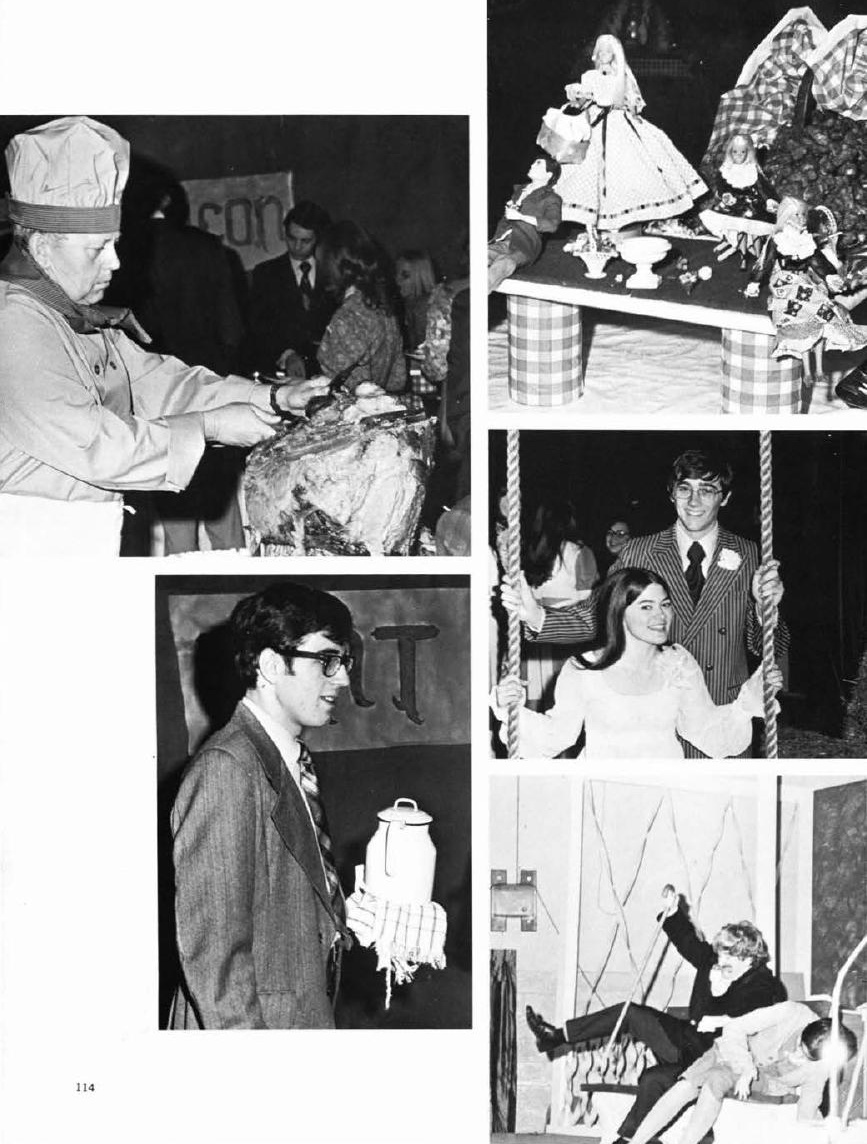


\section{gamma chi presents "a night in the park"}
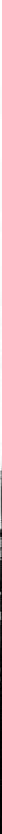


\section{reflections}

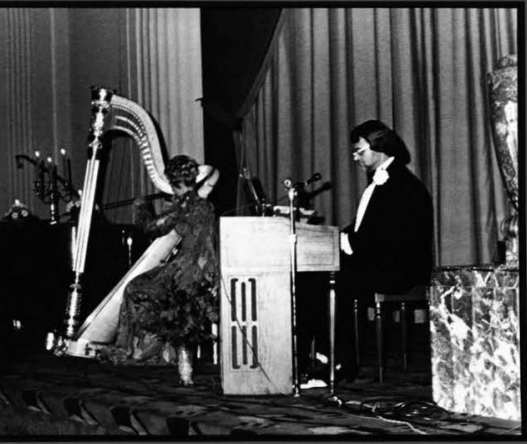

springtime netherlands hilton hall of mirrors flowers $\mathrm{mr}$. and mrs. dick anthony a harp a voice a piano a night to reflect.

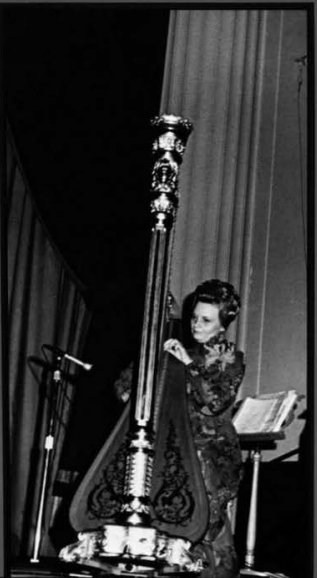



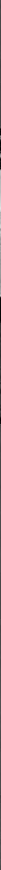


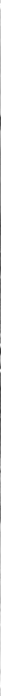




\section{cross country for Christ}

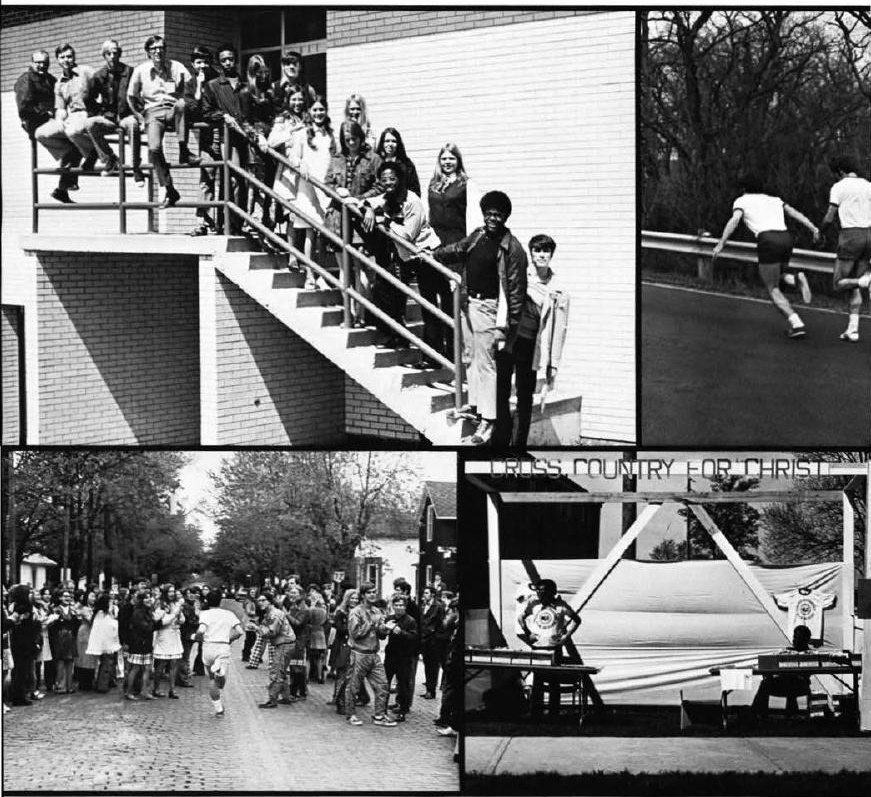

student body project committee 


\section{$\ldots$ goal ... \$60,000!}
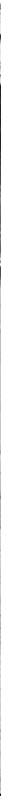


\section{the 1973 cindermen}
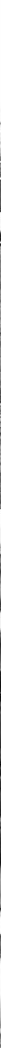

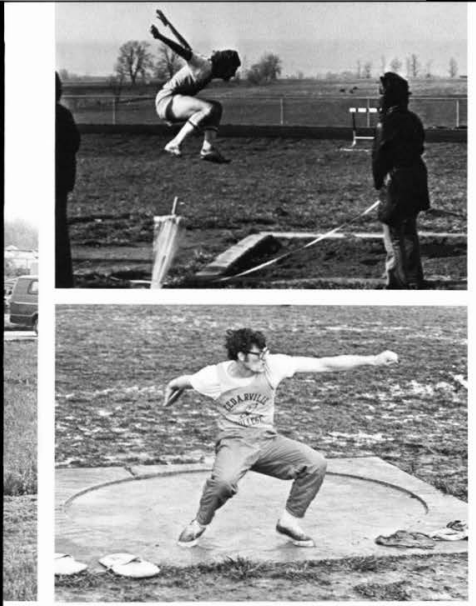

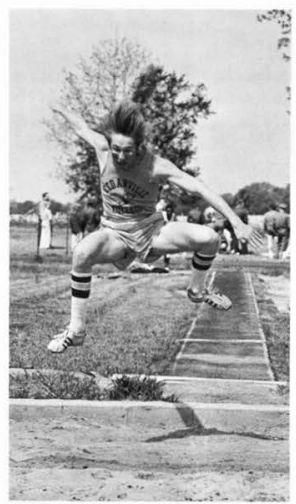

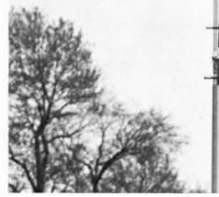

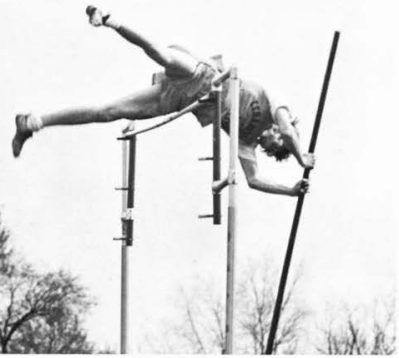



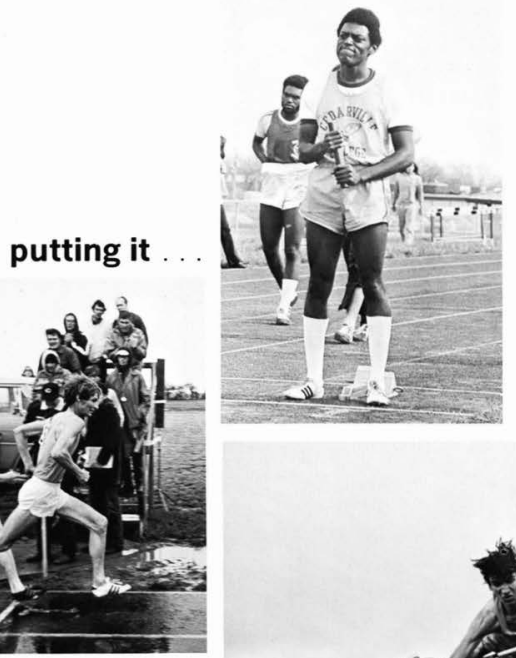

s.
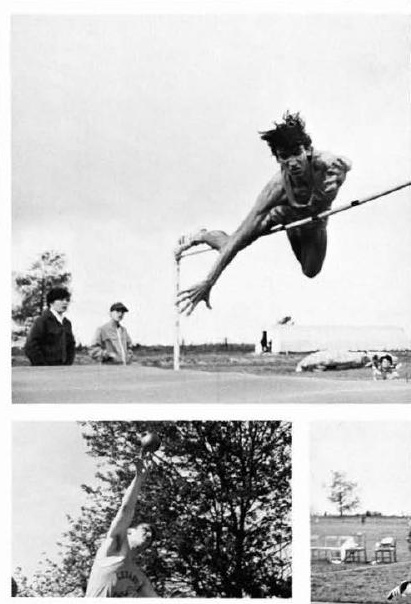


\section{one team ... florida ... a long}

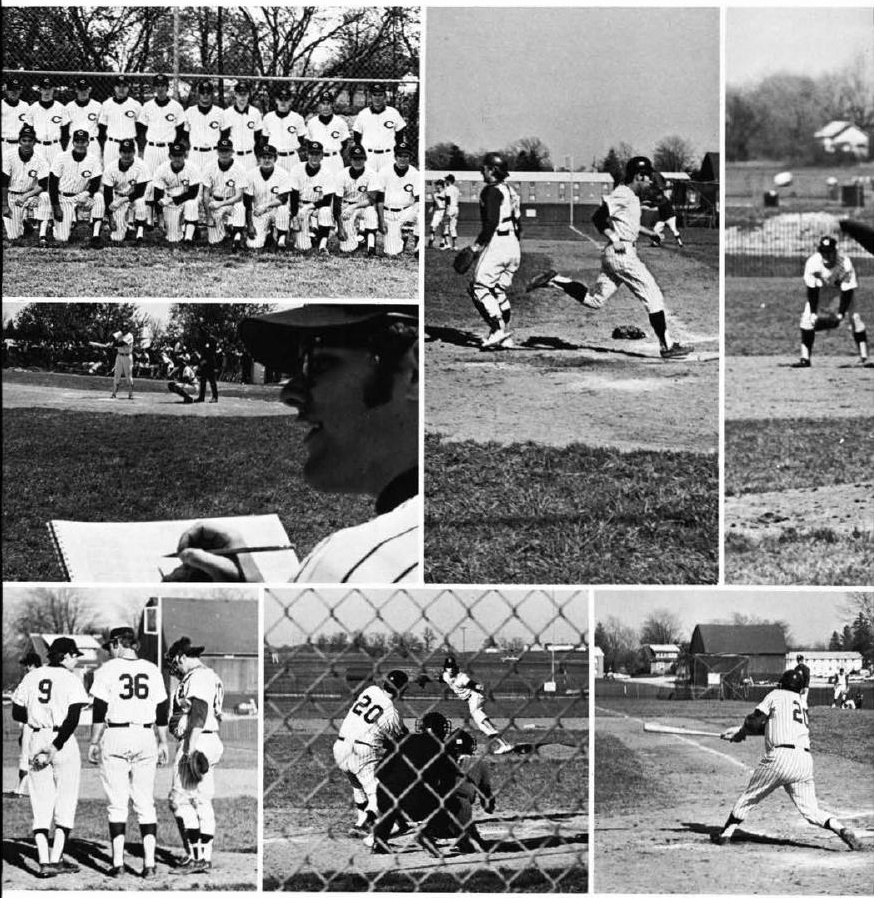




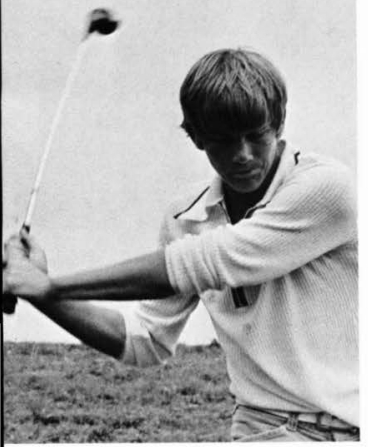

132 physically/golf

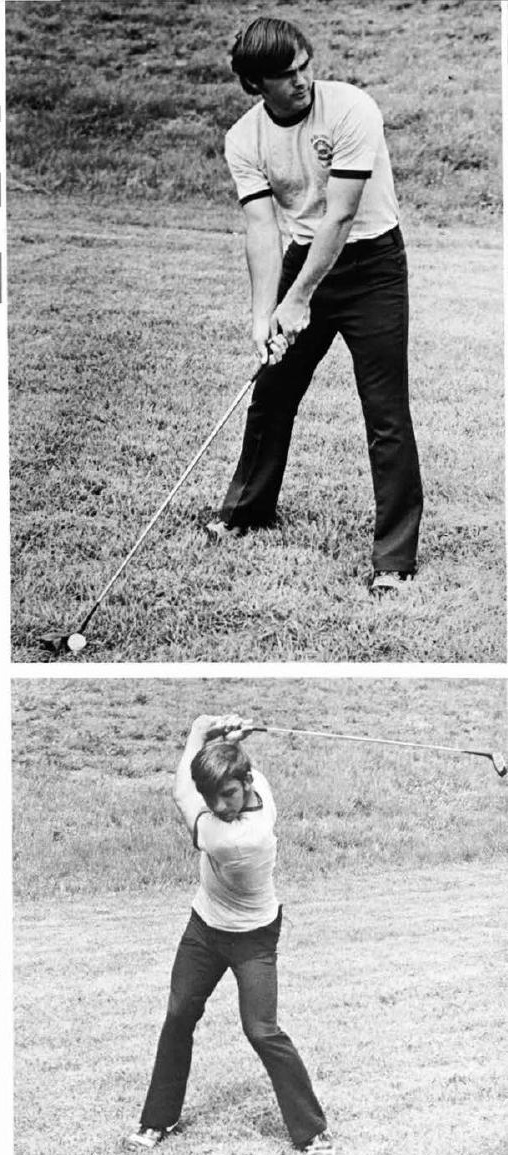




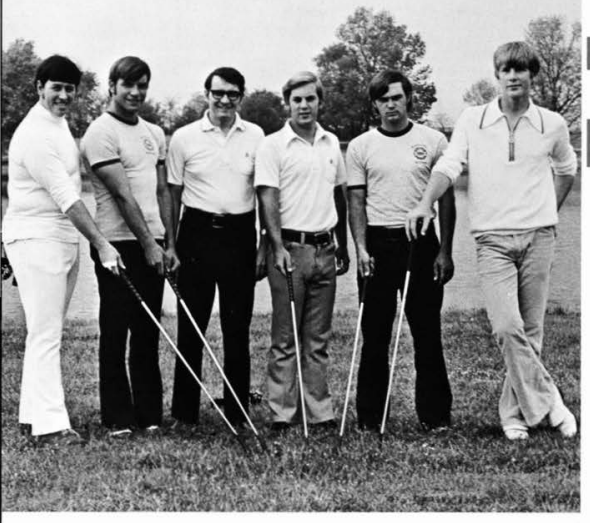

\section{the champs}
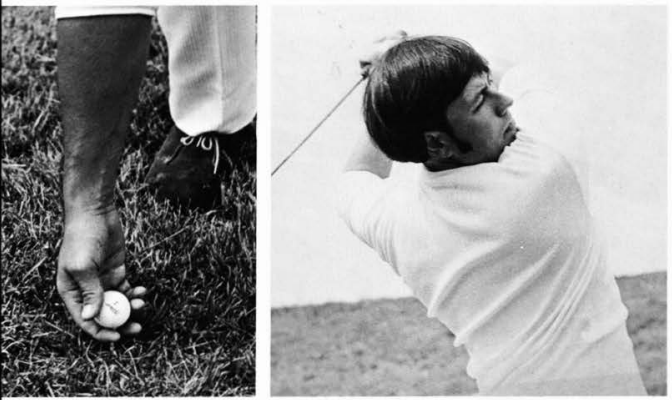


\section{a different team ...}
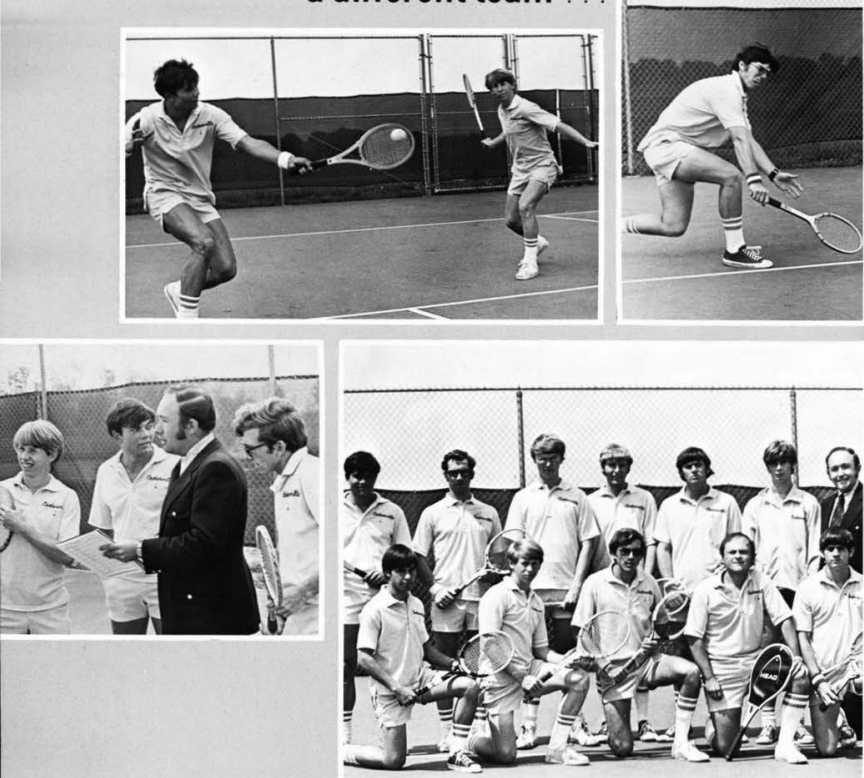

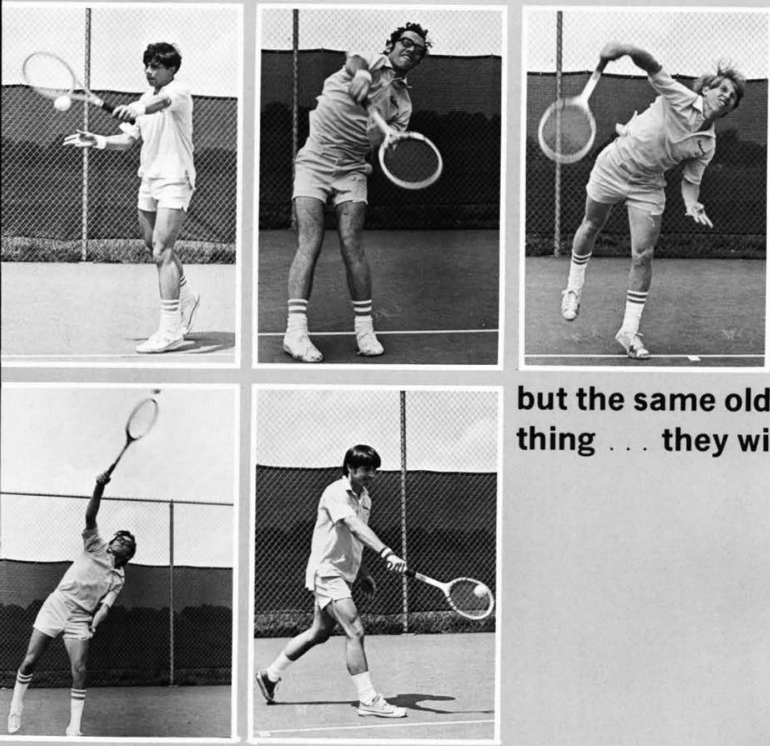

\section{but the same old thing ... they win!}




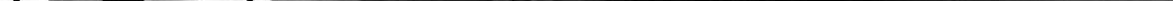




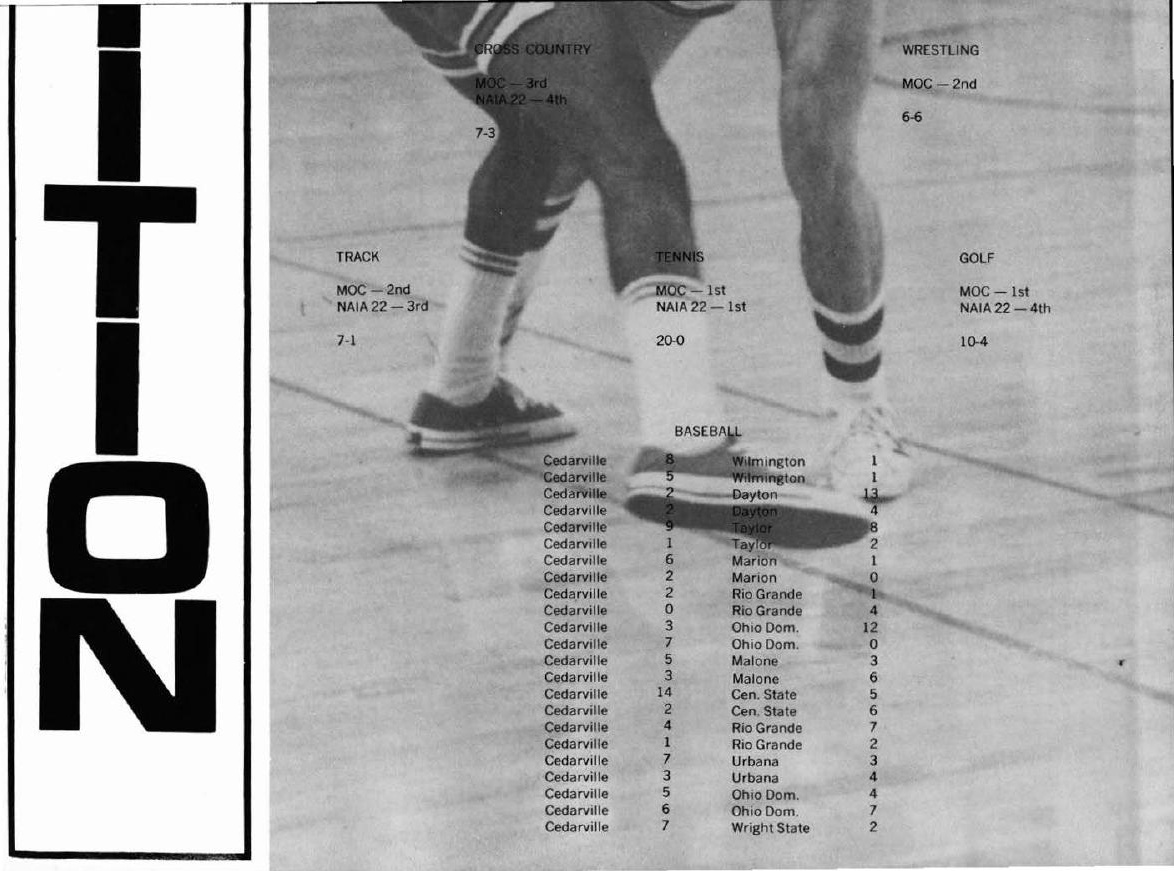




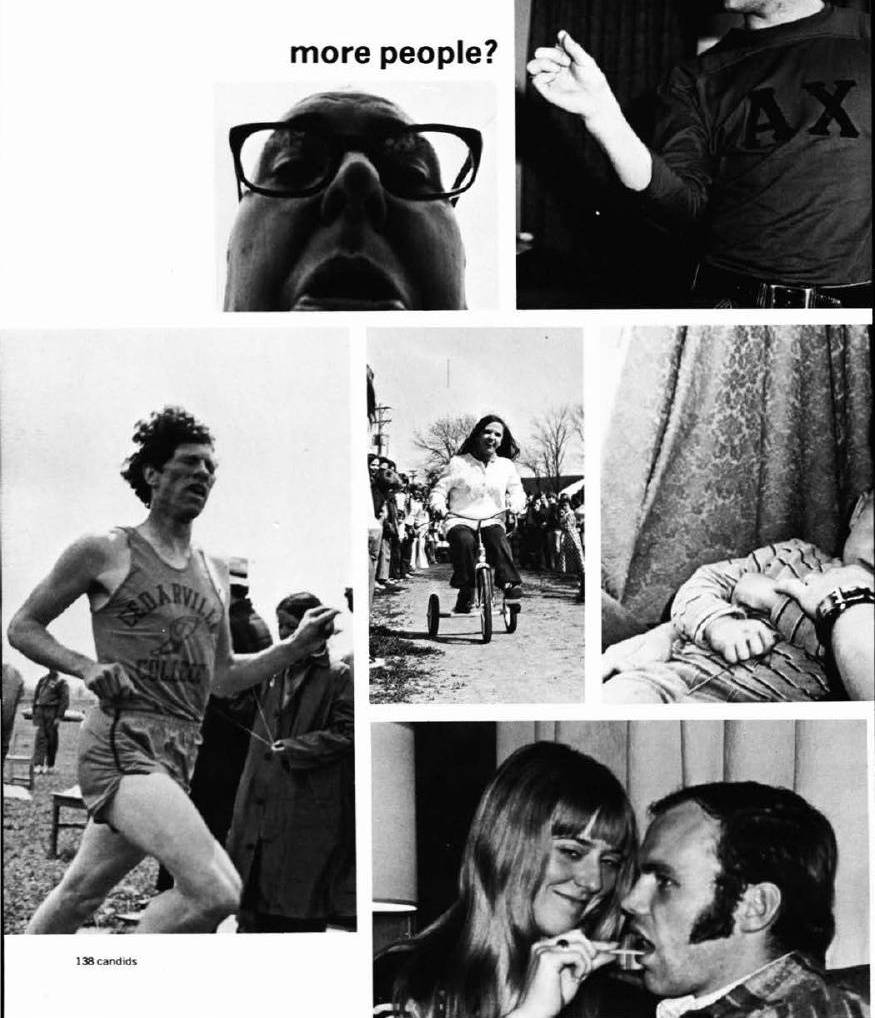



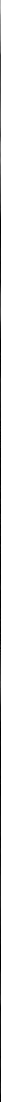


\section{let us bear precious seed ...}
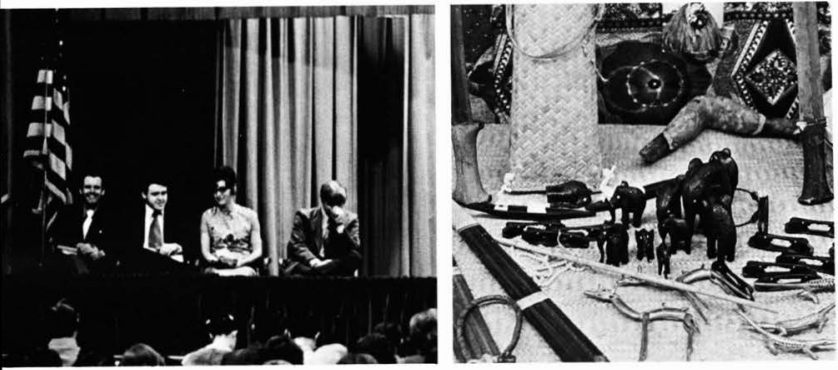

at

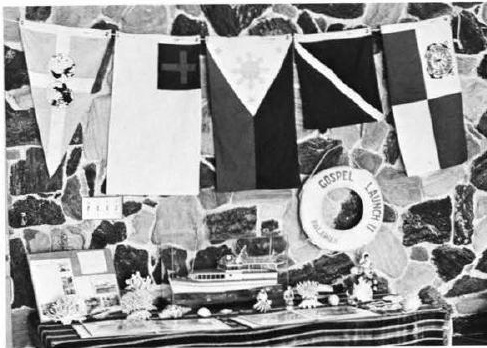




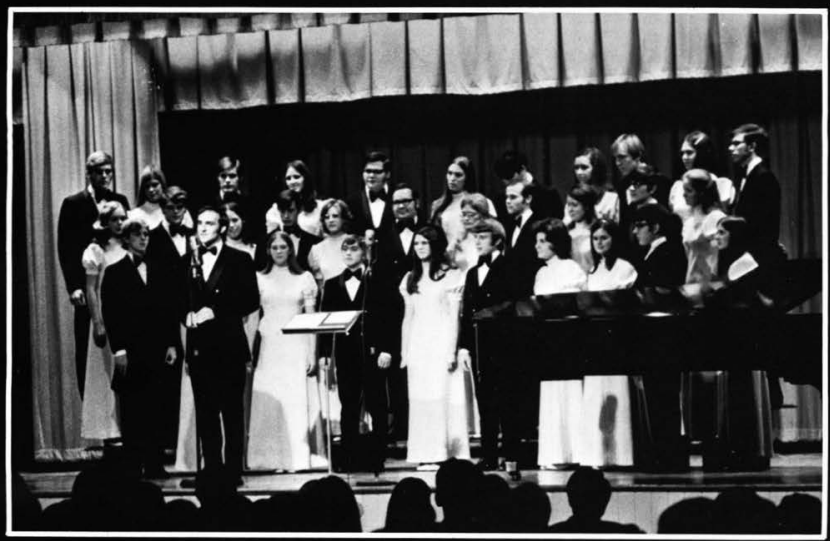

The 1973 Cedarville College Choralaires. under the direction of Lyle J. Anderson presented over twenty-five concerts in Ohio. Indiana. Pennsylvania. Maryland. and Washington, D.C. Their concert consisted of both classical and sacred music.

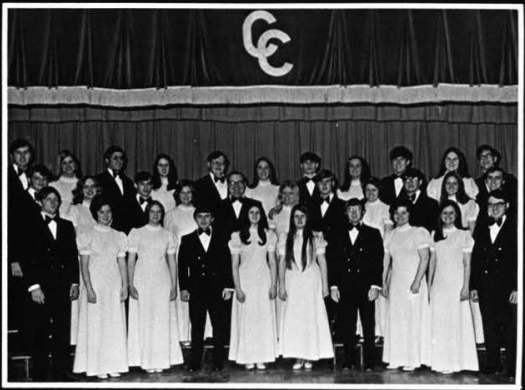



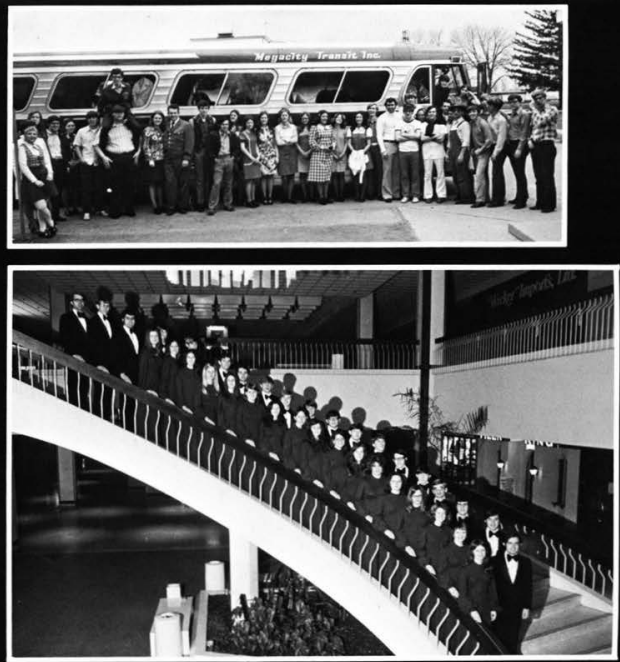

With its own distinctive style. the Concert Choir has been recognized for its choral music performances marked by fine taste and perceptive interpretations. The group has performed before a variety of audiences in churches, high schools, state prisons, and other college campuses.

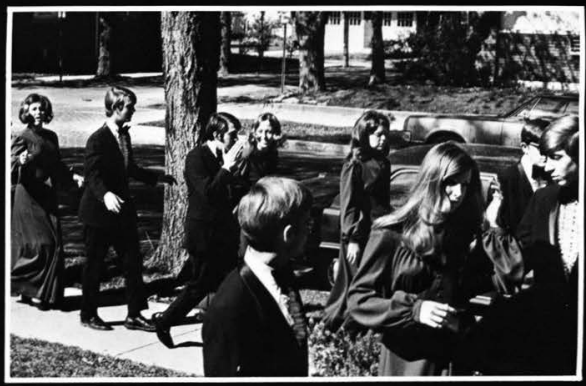




\section{gospel echo trio}

\section{classics quartet}
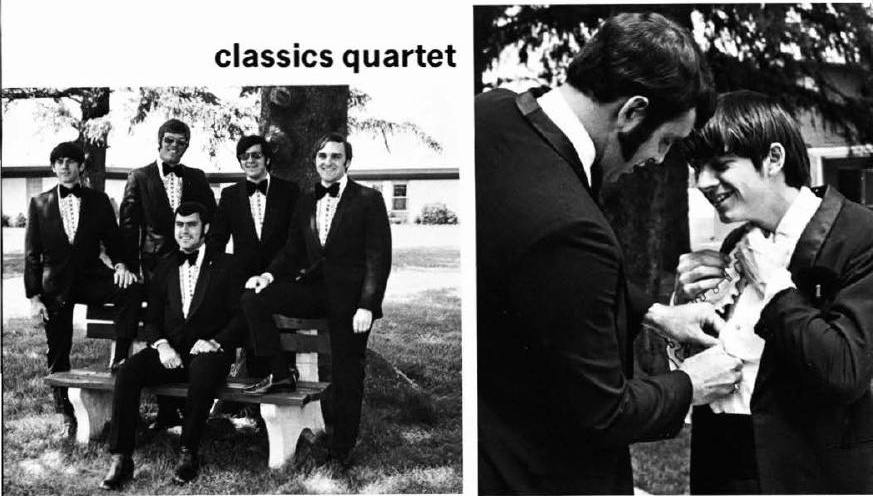


\section{manifestations trio}

inspirations trio
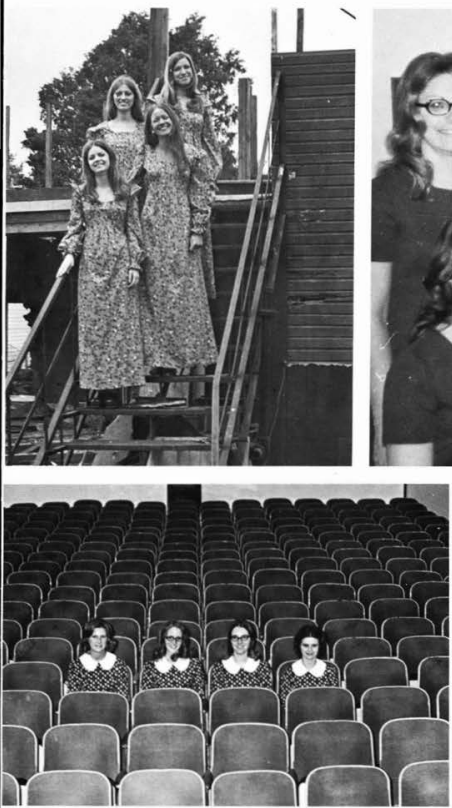

revelation trio

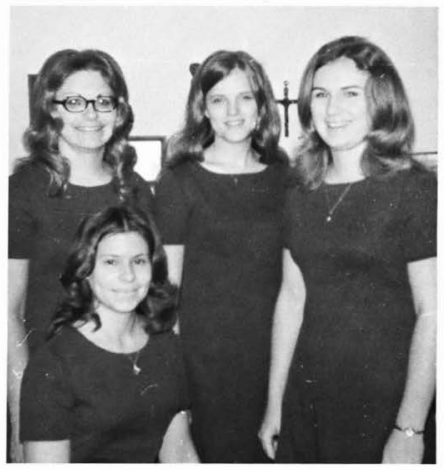



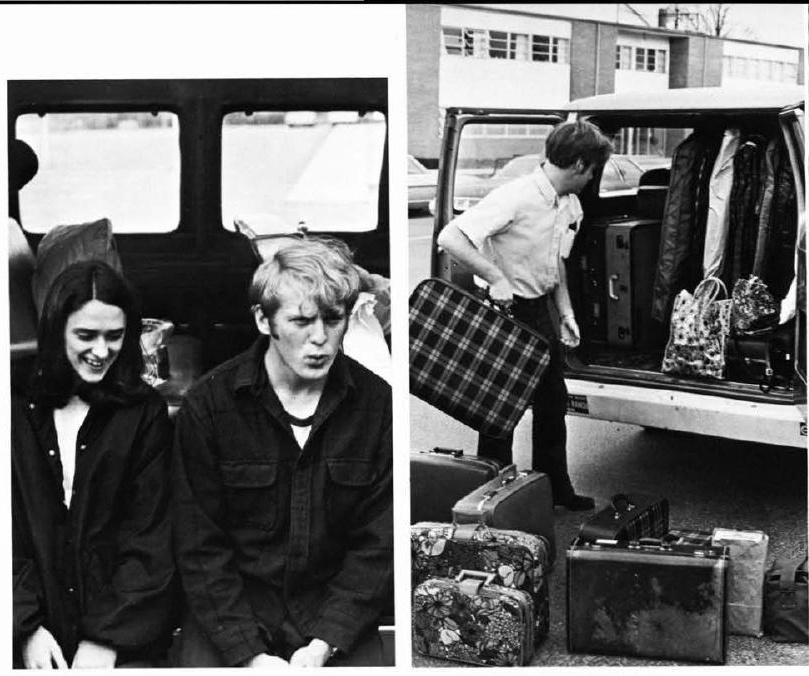

$\mathbf{\gamma}_{\mathbf{1}}$

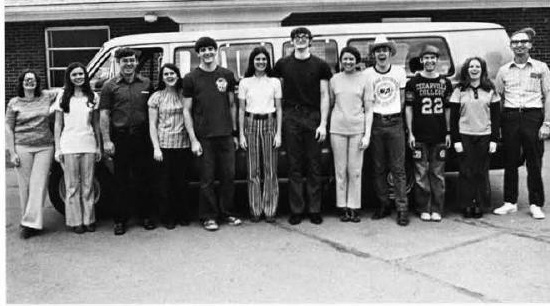



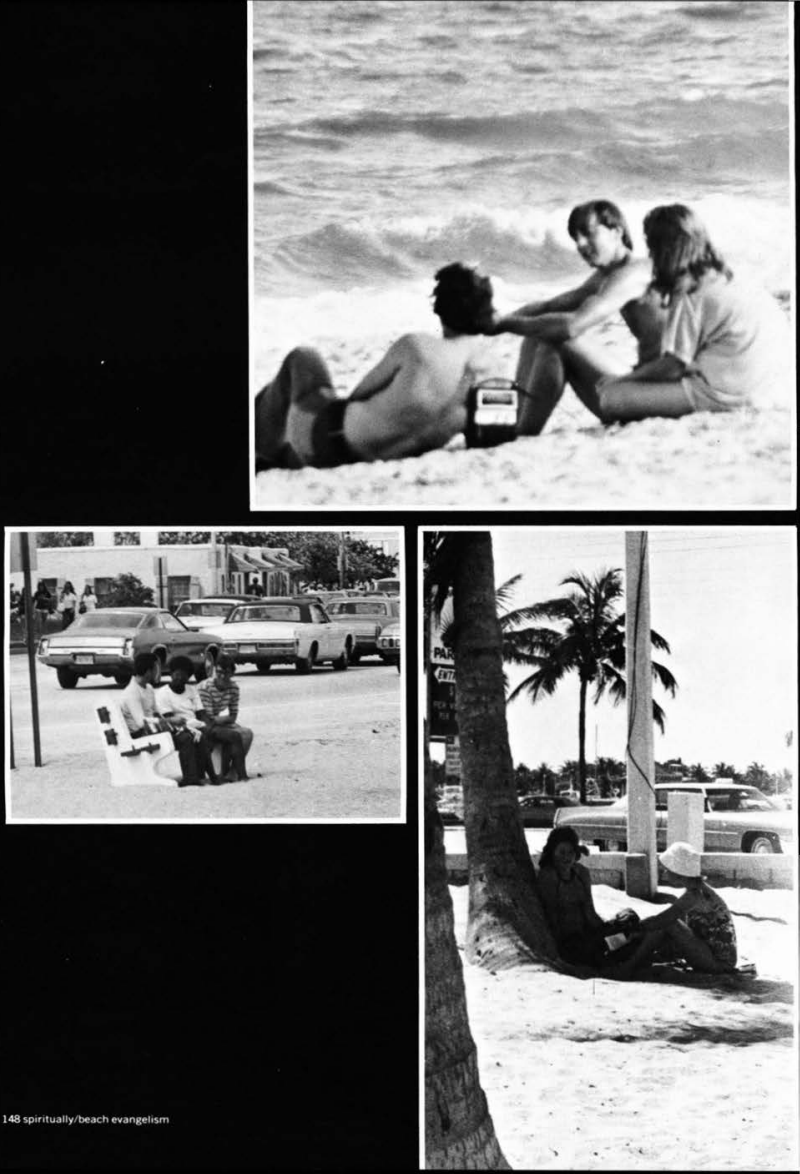


\section{beach evangelism}
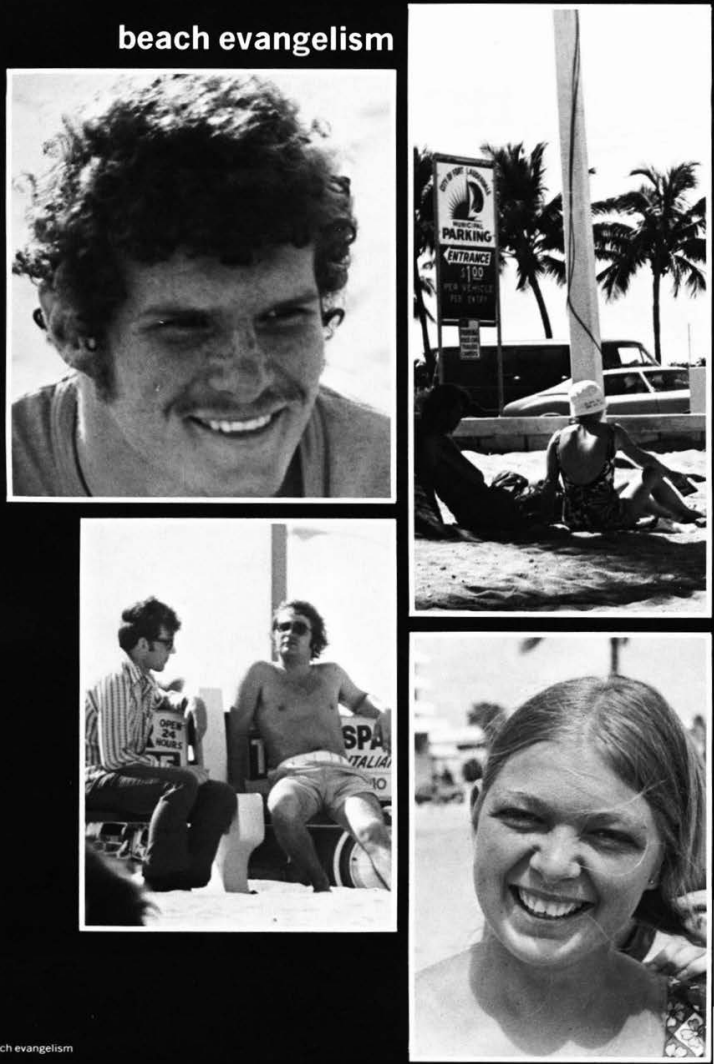

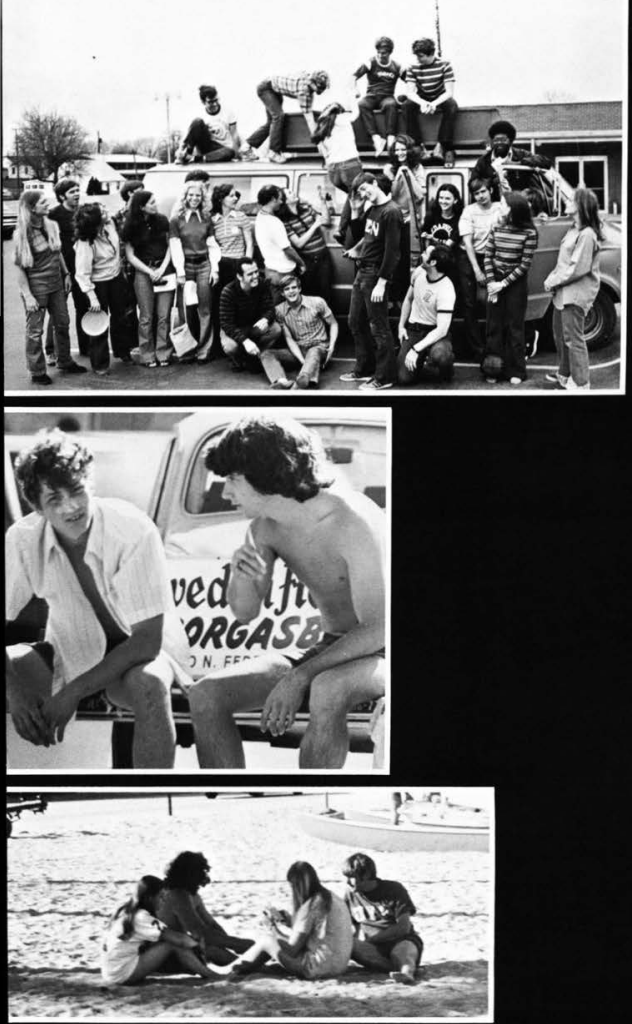
a year ... almost

\section{at a close}
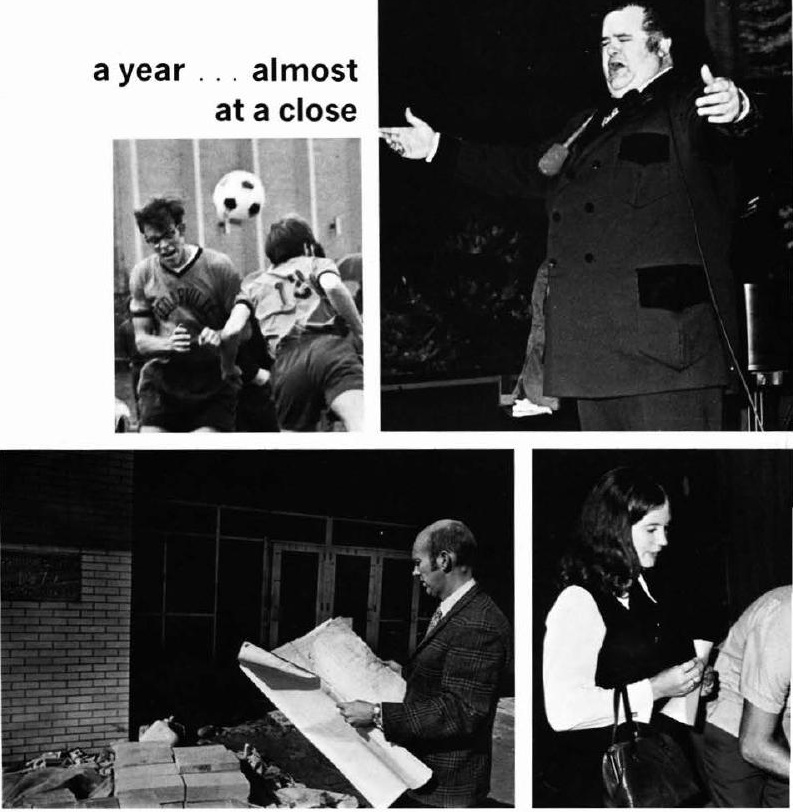

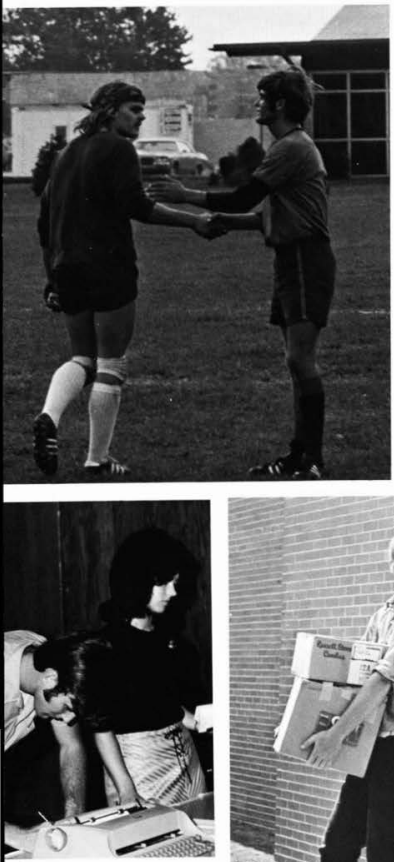

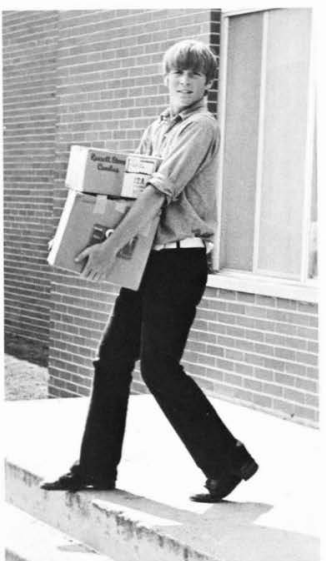

the bad and the good. . 



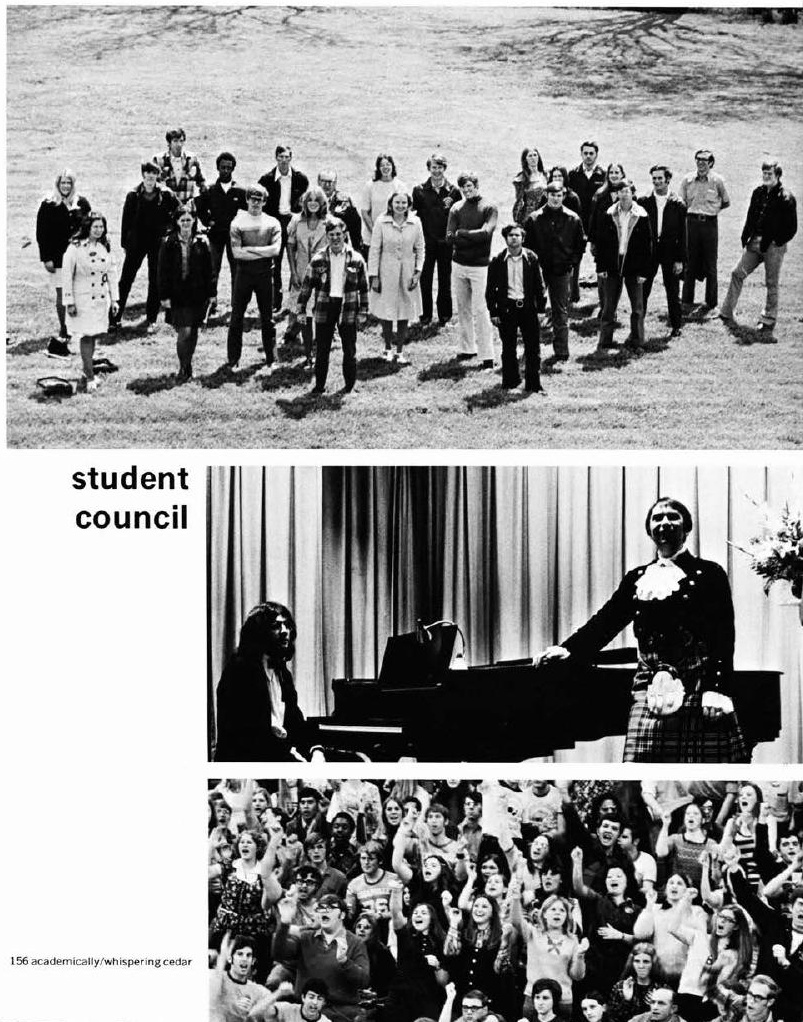



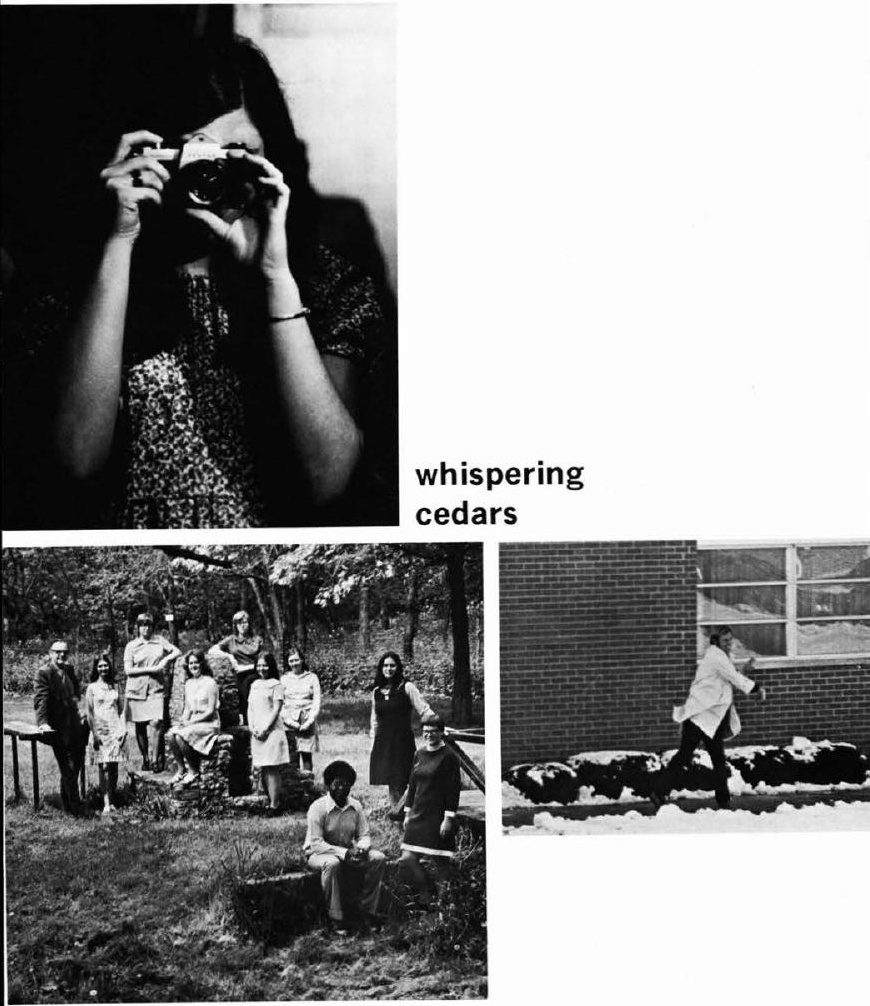

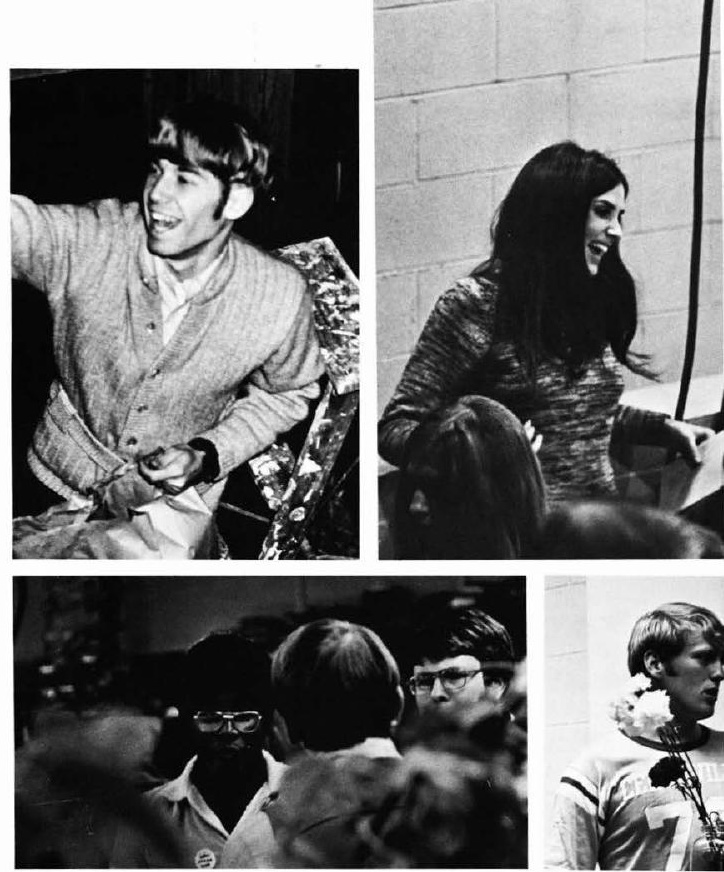


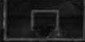

-
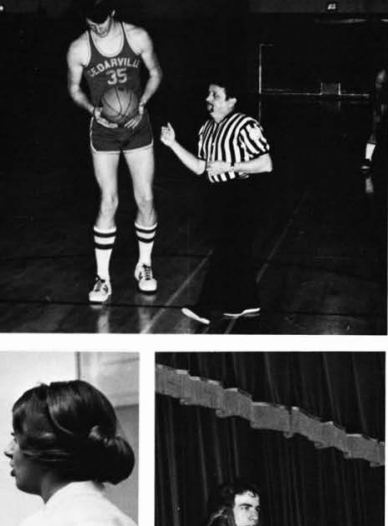

$\sum^{2} z^{2}$

$x^{7}$

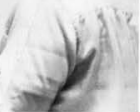

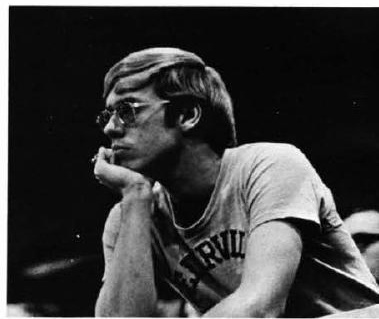




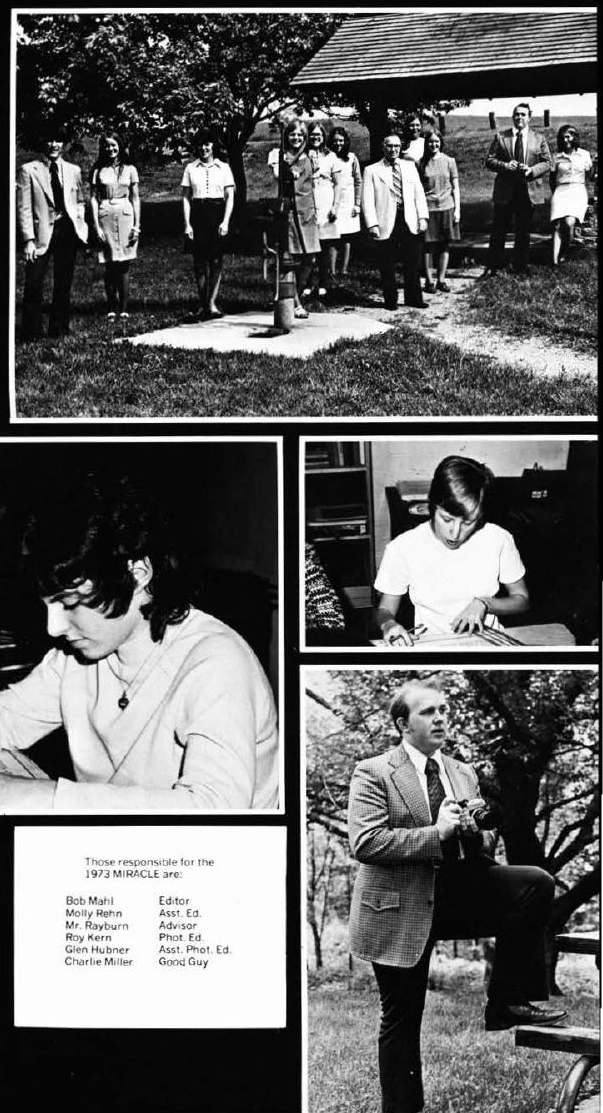




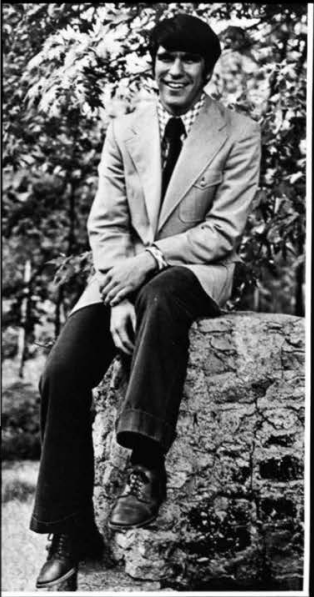

\section{miracle 1973}
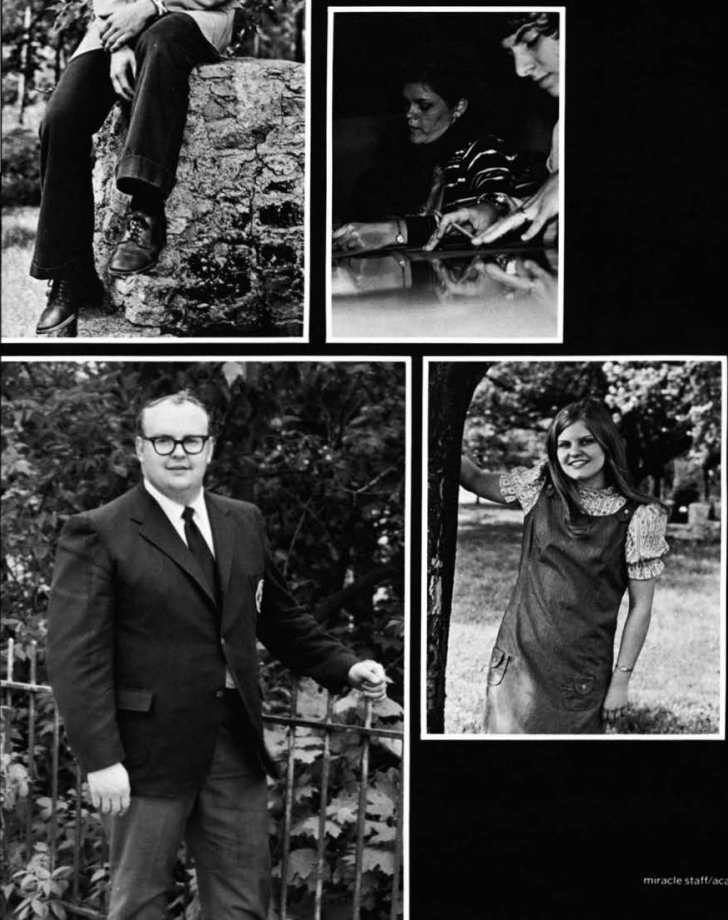

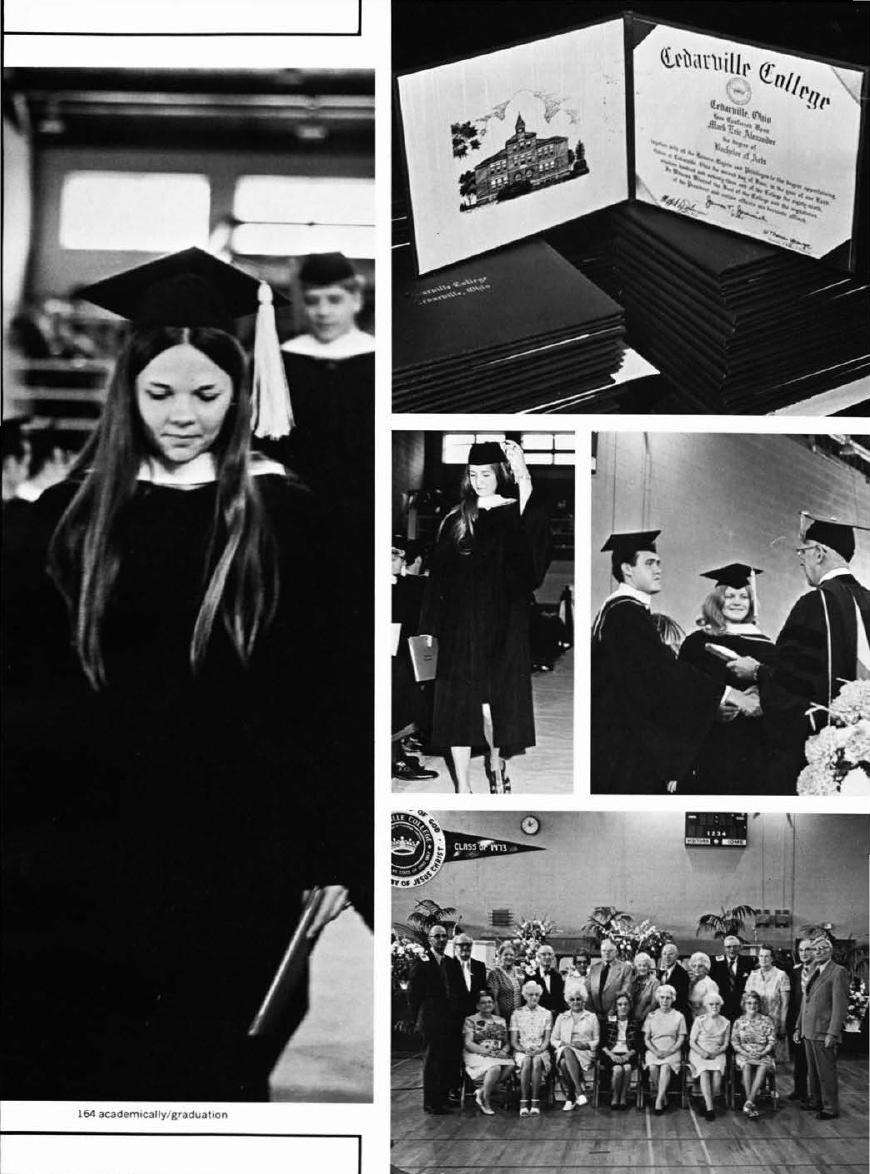


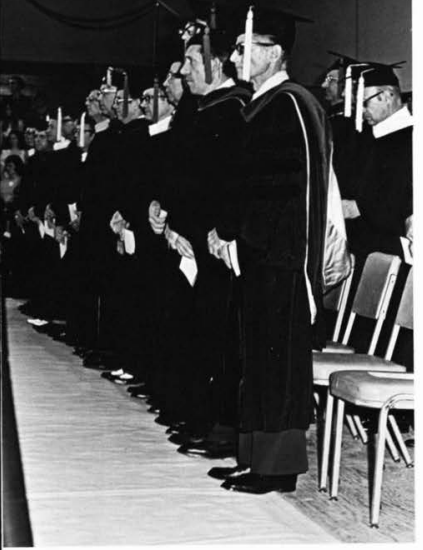

Now that it is all over, the real reaching just begins. All those friends and people you know will no longer be there. There will have to be someone else; and there will.

That's the way it will always be. As long as you are willing to reach out there will be someone there.
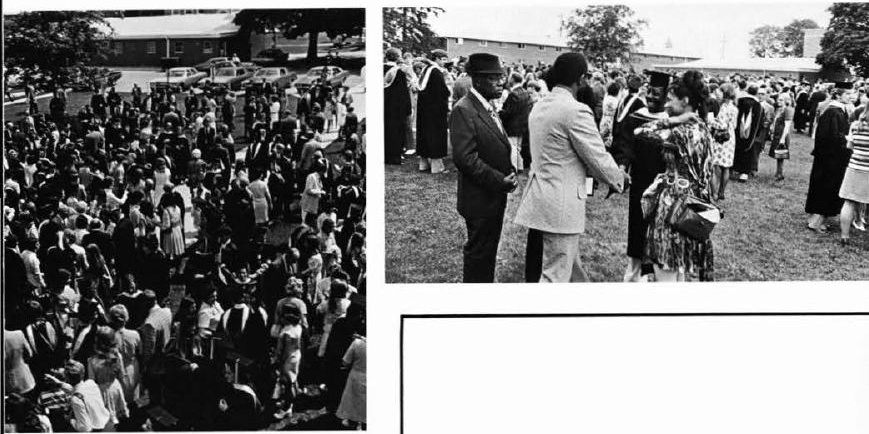
pages 1-11

fall

winter

spring pages 12-65

pages 66-107

pages 108-165

dedication

pages 168-169

faculty

pages 170-181

students

pages 182-206

advertisements .

pages 208-231 



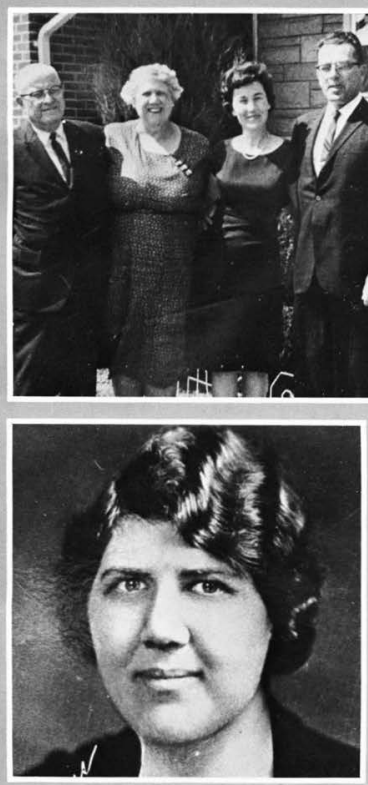

\section{dedicated to:}

mrs.

miriam

maddox

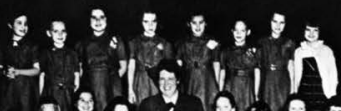

$7.90^{\circ} \cdot 200.04$

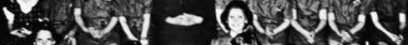

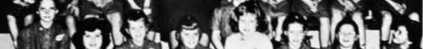
401 (n) 15
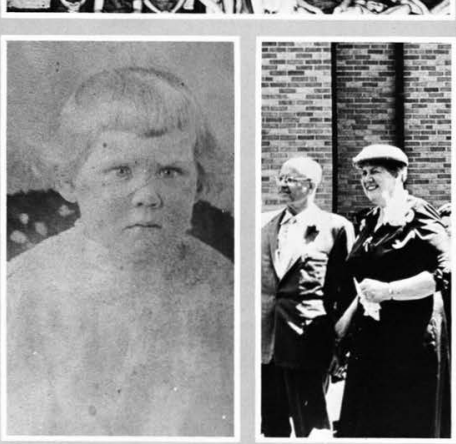

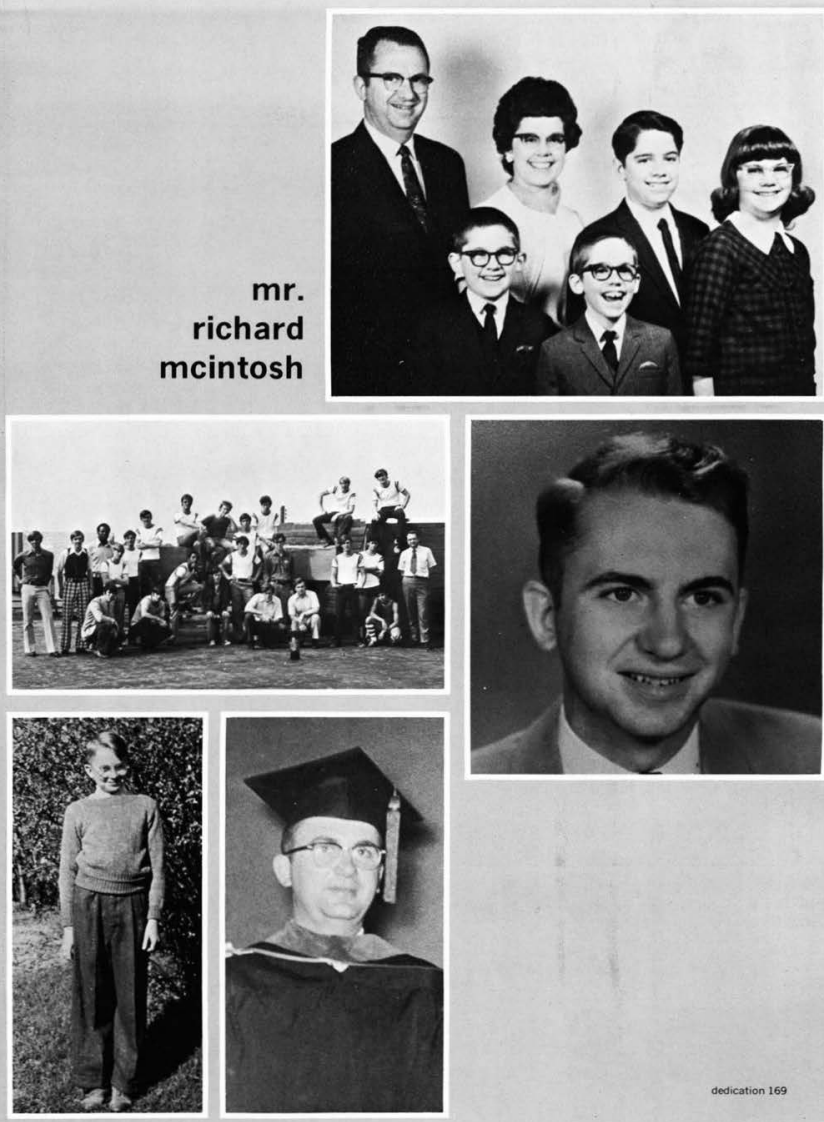


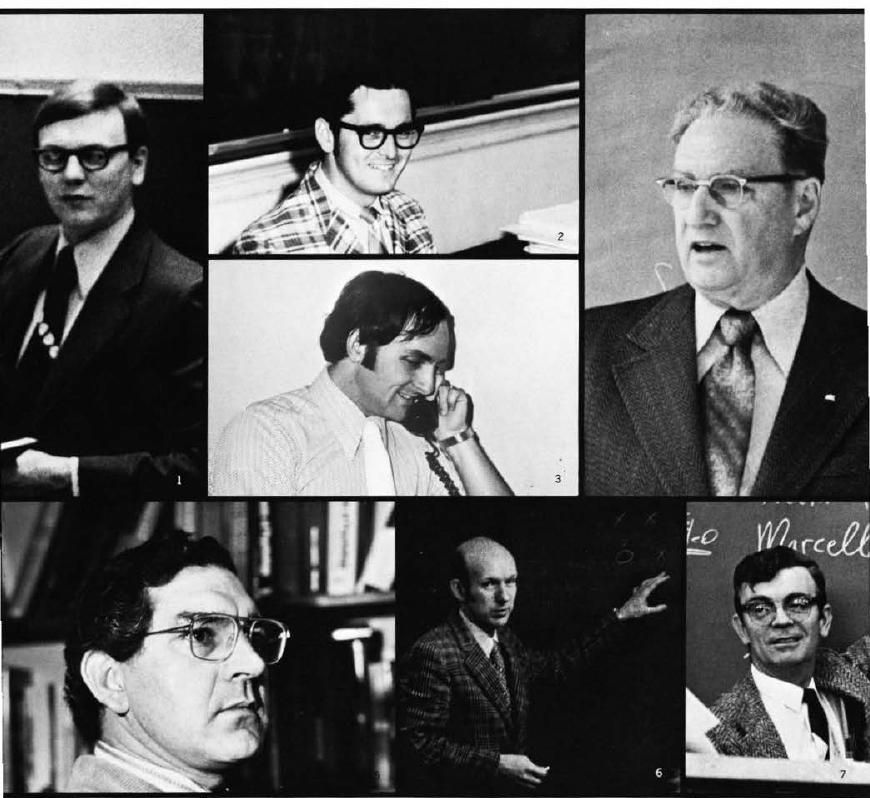

1 Robert D, Abbas, Ph. D. Assistant Pro. fessor of Psychology

2 Merlin F. Ager, Ph D. Protessor of Education

3 Lyle J. Anderson, M.A. Instructor of Music
4 Mead C. Armstrong, D.D. Professor of Bible

5 Stanley N. Ballard, Ph.D. Professor o: Psychology
6 Donald P. Baumonn, Ph.D. Professor of Biology and Chemistry

7 Harmon Bergen, M. A. Associate Professor of English 


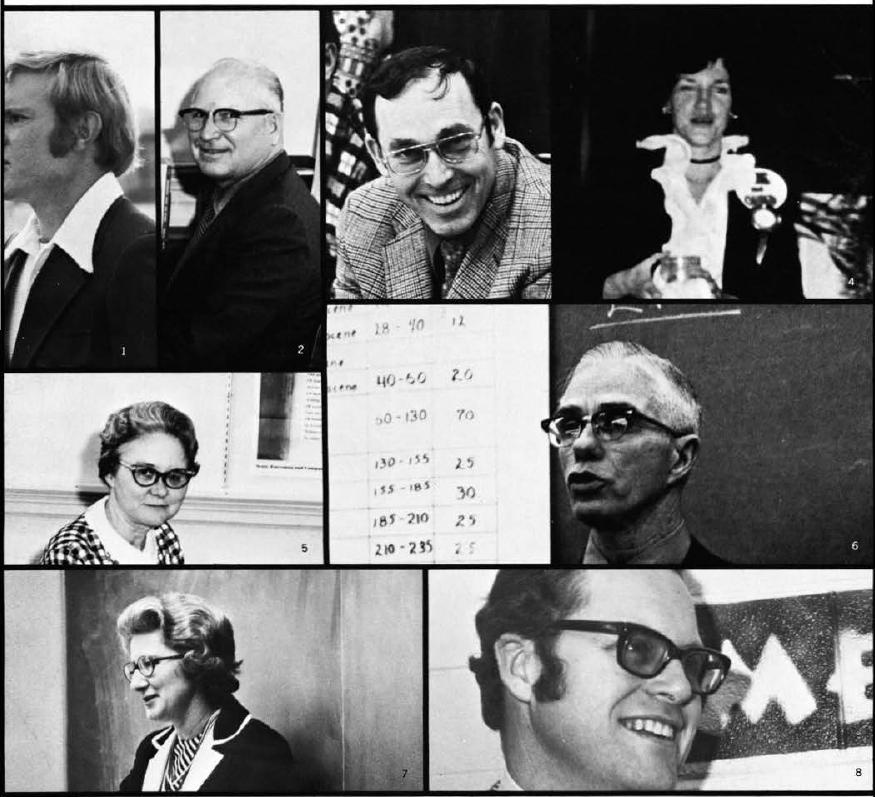

1 Paul S. Berry, M.A. Assistant Protessor of Physical Education

2 Howard T. Burt, M.A. Part-time Instructor of Education

3 Donald Callan. Ph.D. Professor of Phy. sical Education
4 Patsy L. Dixon, M.Ed. Assistant Protessor of English

5 Irma M. Dodson, M.A. Associate Pro fessor of Education

6 Austin D. Elmore, M. A.T Associate Pro fessor of Biological Science
7 Jean Fisher M.A. Associate Protessor of Christian Education

8 Dwayne I. Frank, M.S. Associate Professor of Education 


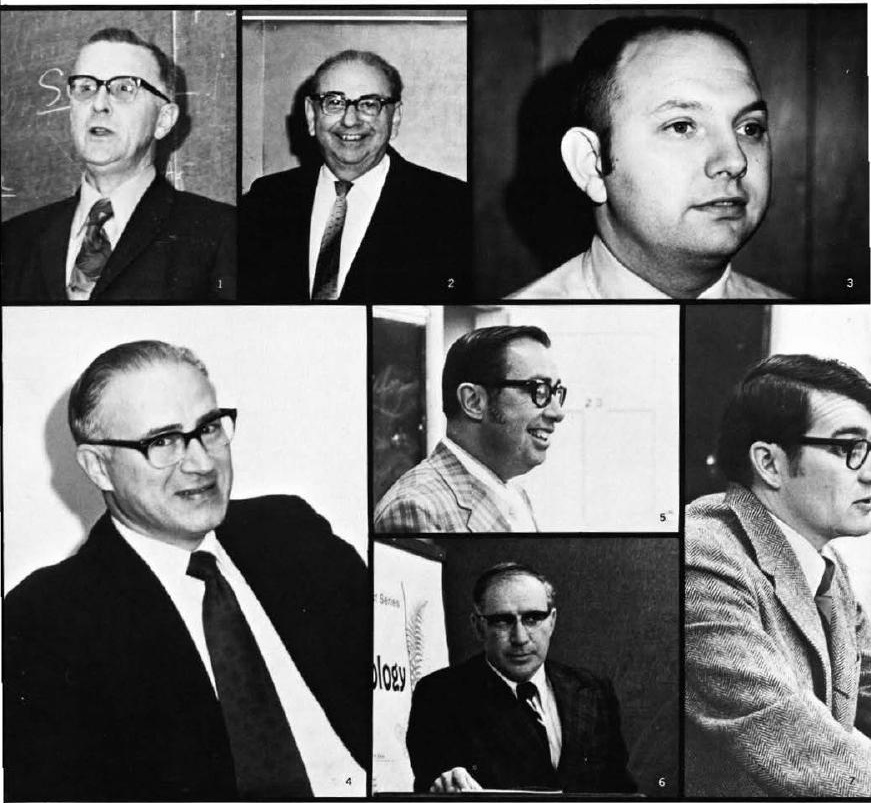

1 L. Bert Frye, M.A.T. Associate Professor of Physical Science

2 Raiph B. Gale, M.A. Associate Professor of History

3 Paul H. Gathany, B.A. Radio Station Manager, Instructor of Speech
4 Edward L. Greenwood, M.A. Associate Protessor of English

5 James R. Grier. M.Div. Assistant Professor of Philosophy
6 Walter L Griffith, Ph.D. Professor of Bio logy

7 Robert Gromacki. Th. D Professor of Bible and Greek 


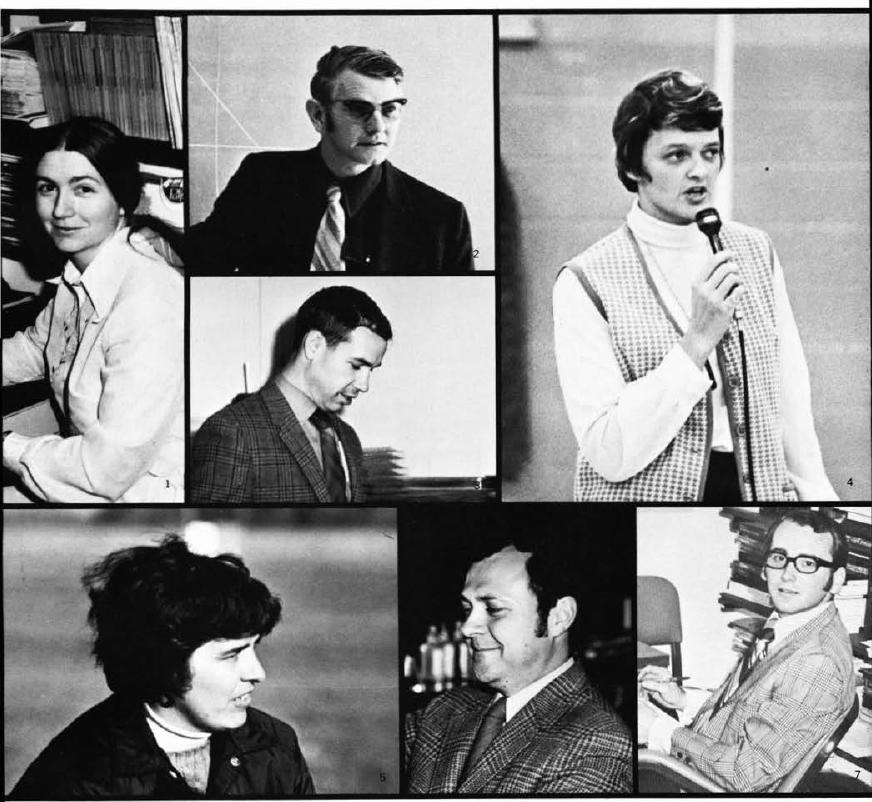

1 Sharon B. Hahnlen, B.S. Assistant Pro fessor of Foreign Language

2 E. Dane Harvey. M.S. Assistant Professor of Physics and Mathematics

3 Larry S. Helmick, Ph.D. Associate Pro fessor of Chemistry
4 Maryalyce Jeremiah, M.A. Assistant Pro fessor of Physical Education

5 June F. Kearney, M.Ed. Associate Professor of Physical Education
6 Lawrence N. Killian, M.S. Associate Pro fessor of Biological Science

7 Ronald M. Grosh, M.A.T. Assistant Pro tessor of English 


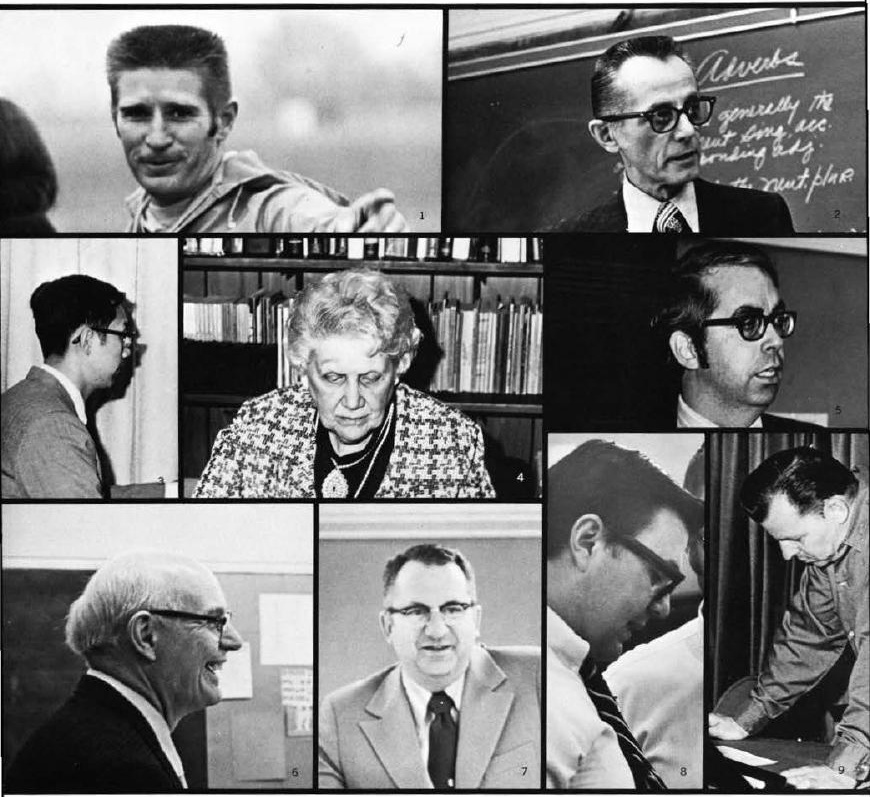

1 Elvin R. King, M.Ed. Assistant Professor of Physical Education

2 George L. Lawlor. Th.D. Professor of Greek and Bible

3 Lawrence N-L. Lo, M.Mus. Assistant Professor of Music
4 Miriam B. Maddox. B.A. Assistant Professor of Speech

5 David L. Matson, M.A. Associate Pro fessor of Music

6 Cleveland McDonald. Ph.D. Professor of Social Science
7 Richard $T$ Mcintosh. Th.M Associate Professor of Bible

8 Allen L. Monroe, Ph.D. Professor of So cial Science

9 Robert C. Monroe, Ph.D. Associate Pro fessor of Music 


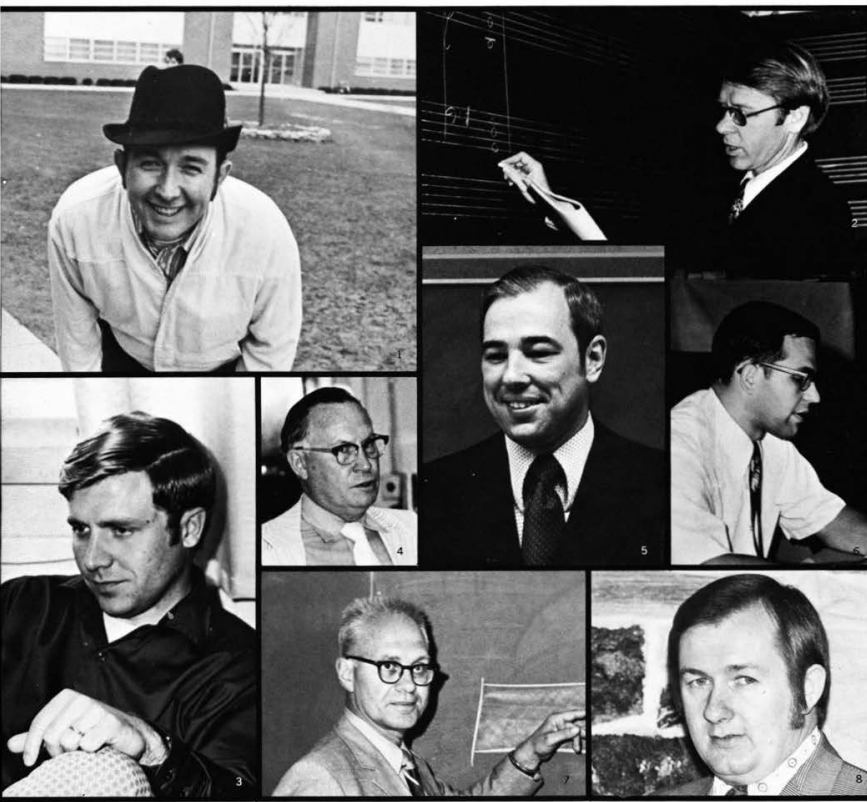

1 J. Murray Murdoch. Ph.D. Prafessor of History

2 Jack R. Payne, M.M. Assistant Protessor of Music

3 James $R$. Phipps. M.A. Assistant Professor of Speech
4 Marlin L. Rayburn, M.A. Associate Pro. fessor of Speech

5 Jack R. Riggs, Th.D. Professor of Bible

6 William R. Riter, M.S., C.P.A. Assistant Professor of Accounting
7 Jack H. Scott. Ph.D. Professor of Psychology

8 James E. Seaman, M.B.A. Assistant Pro fessor of Marketing and Management 


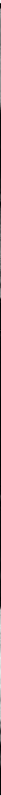

1 Lila Christensen Seaman, M.S.Ed. Assis. tant Professor of Education

2 Edward E. Spencer, M.A. Associate Protessor of English
3 Ralph M. Werner. M.Ed. Assistant Pro fessor of Music

4 Daniel E. Wetzel, Ph.D. Professor of Phy. sics and Mathematics
5 Donald T. Wilcoxon. M. B.A. Assistant Professor of Business

6 L. Daryle Worley. M.M. Assistant Professor of Music 


\section{administration}

clifford johnson academic dean

kenneth st. clair business director

\section{donald rickard dean of students}

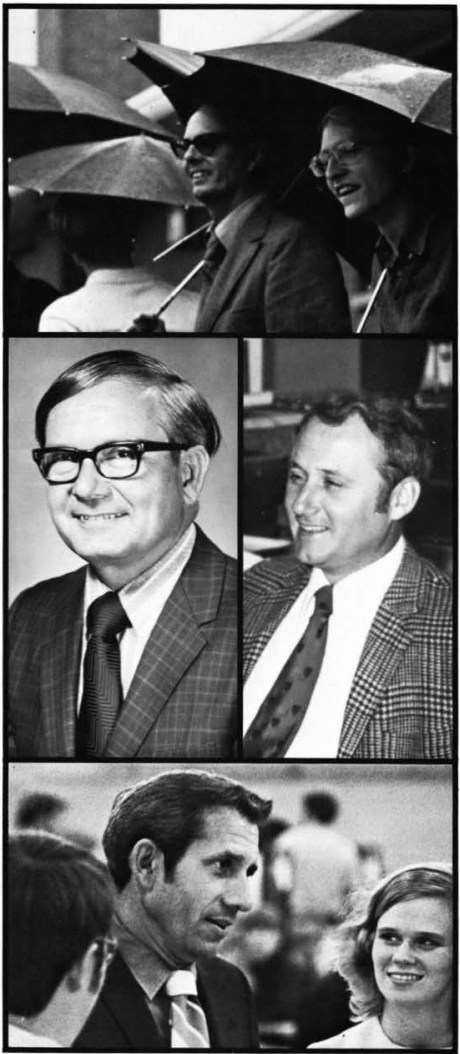

lee turner director of development 


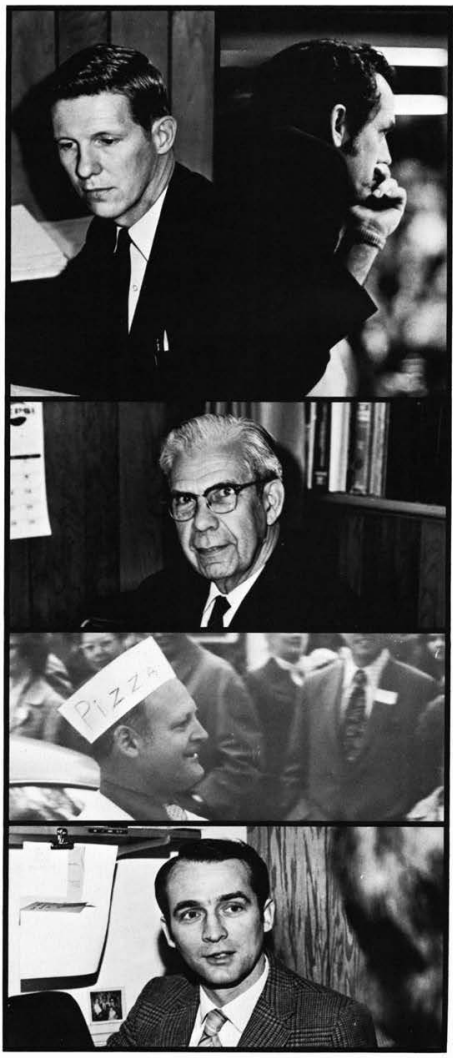

staff

david gidley director of financial aid

harold green campus pastor

c.b. hurst registrar

thomas loper dean of men

kenneth nichols director of student activities 


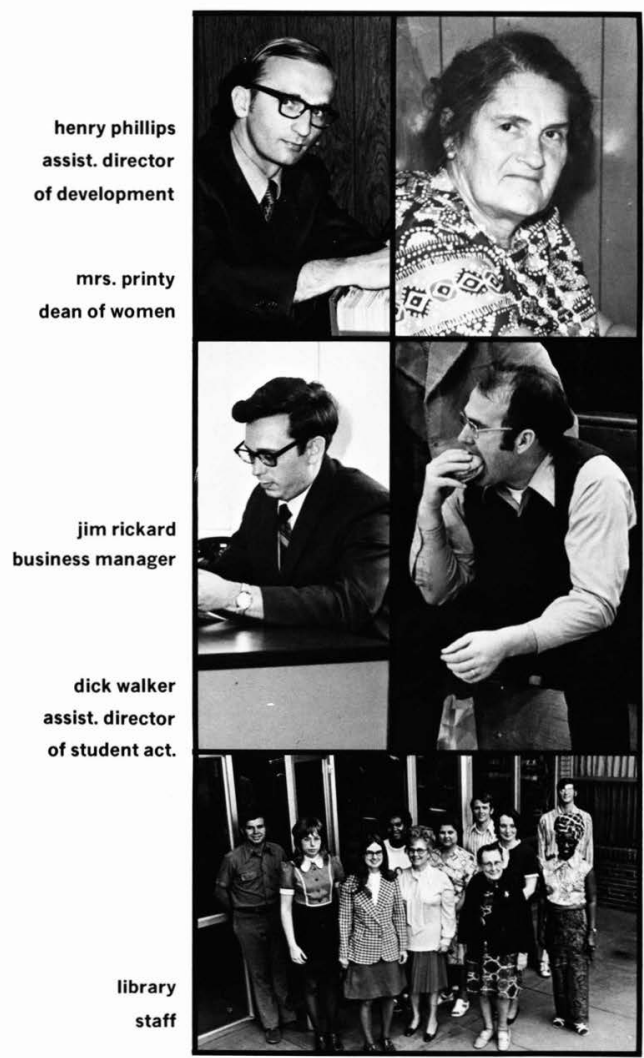




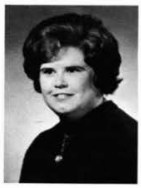

Nancy Fissel
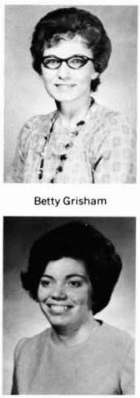

Helen Toinette King

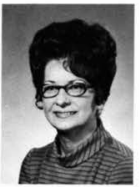

Marion Payne

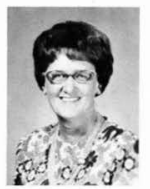

Dorothy M. Spencer

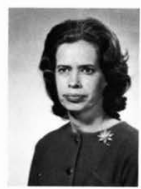

Irene Gidley

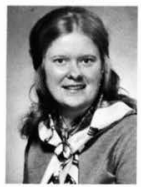

Maxine Hague

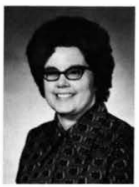

Barbara Mclntosh

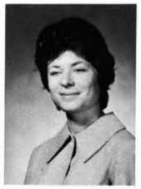

Mary Lynne Peterson

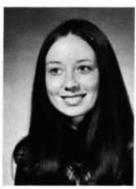

Peggy Weeks

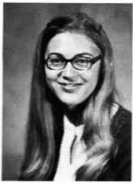

Christine Giese

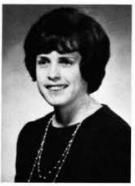

Elayne Howard

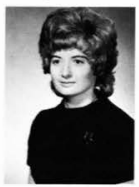

Lois Mclain

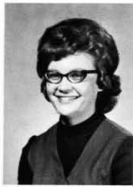

Lila Seaman

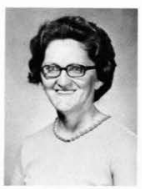

Lois Worley
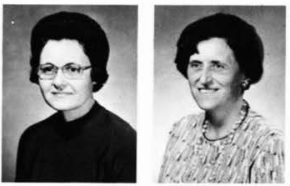

Margaret Green

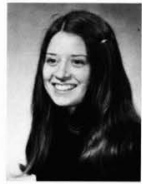

Melinda Howard

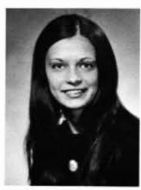

Linda McNiece

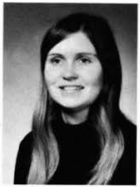

Sandra Shees

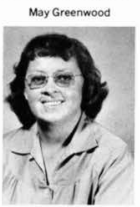

Eunice Johnson

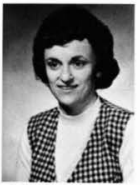

Patricia Monroe

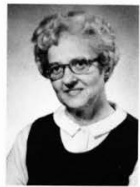

Fiorence Slabaugh 


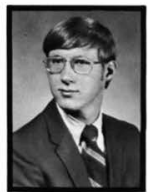

Mark E. Alexander

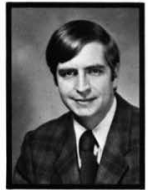

James E. Bates

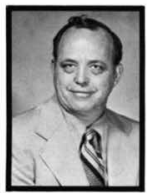

Norman Bosworth

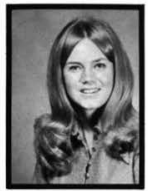

Kathy A. Burkhard

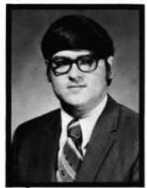

David L Butler

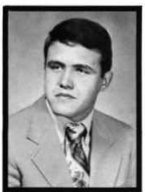

Andy E. Amos

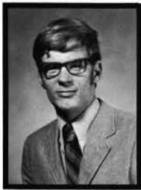

Arthur R. Bedell

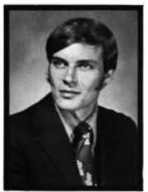

David Branon

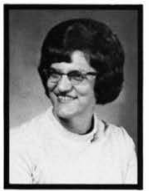

Lillian A. Burkhart

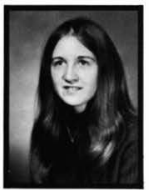

N. Hope Campbell

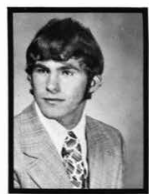

William Bacheller

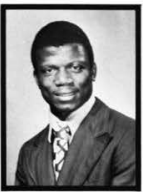

Ernest M. Benson

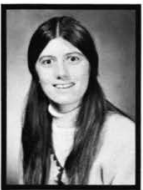

Barbara Brosius

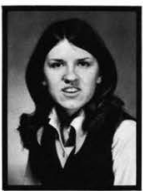

Lois Burlingame

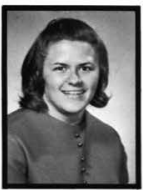

Phyllis Carey

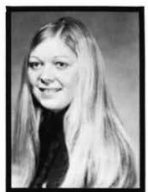

Anne Bailey

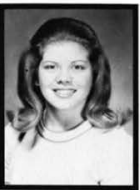

Carol Bierbaum

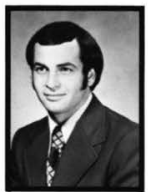

Randy A. Brown

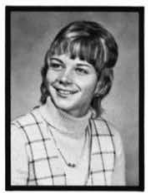

SherryL. Burns

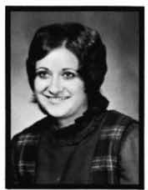

Edythe A. Carity

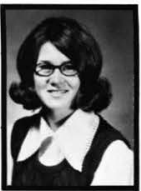

llinda A. Baker

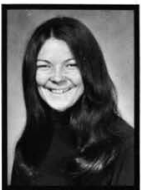

Donna T. Bingham

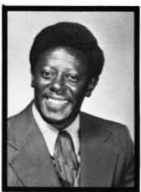

Asa G. Browning

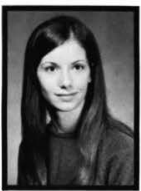

Mary Ann Butcher

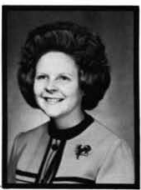

Janice Cason 


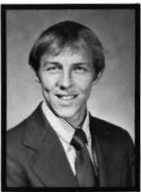

James A. Cavey

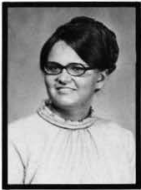

Marjorie A. Cogan

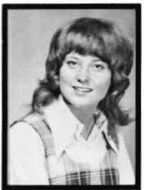

Roxane R. Davis

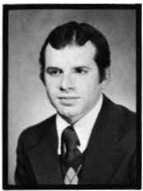

Kenneth L. Dibble

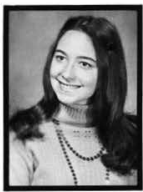

Jane M. Emerson

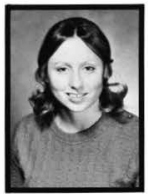

Becki Chandes

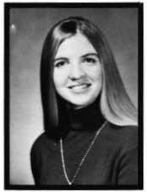

Susan J. Cook

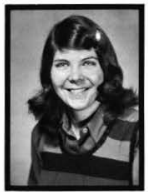

Rebecca G. Decker

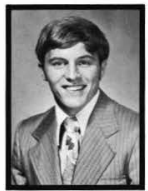

Lee Earl Eck

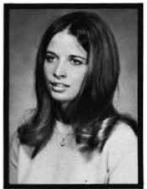

Debbie L. Eplee

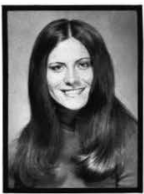

Linda R. Chute

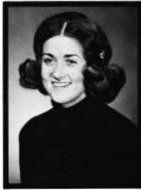

Beth Ann Cooley

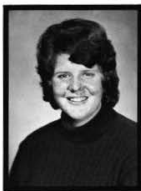

Karen L. DeMars

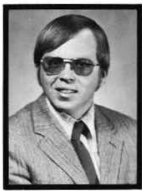

Russell T. Elkin

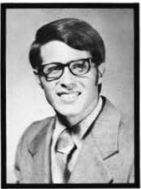

Daniel J. Estes

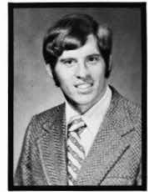

Terry Clapp

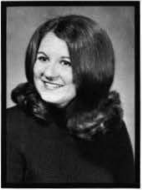

Ruth Ann Coombs

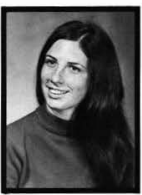

Carol L. Dernos

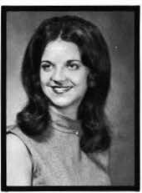

Janet G. Ellis

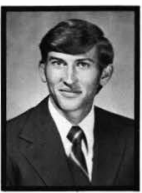

Tom D. Farlow

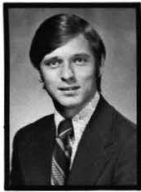

Ronaid E. Clarke

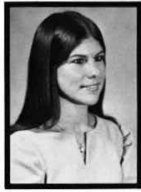

Yronna Cope

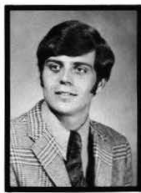

Michael Dersham

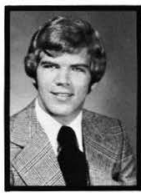

Robert Ely

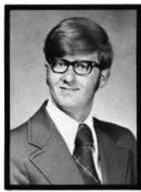

John W. Fiest 


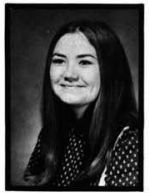

RaeBelle Fisher

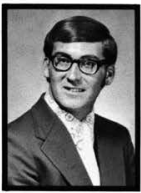

Ed Gibbons

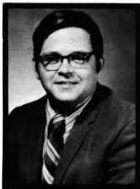

Keith R. Hague

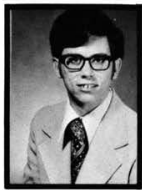

Stephen M. Harriman

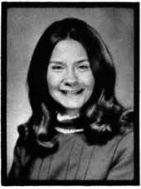

Janet Hillery

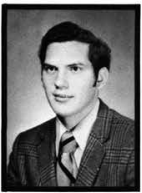

Harold P. Flood

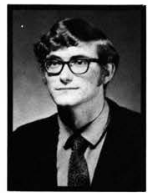

David Globig

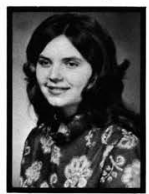

Susan D. Hall

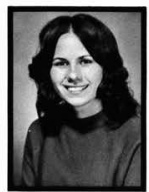

Janalee K. Harris

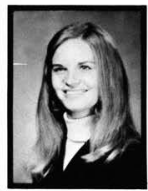

Cynthia E. Hofert

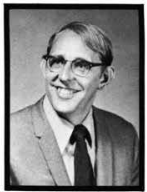

Paui E. Francisco

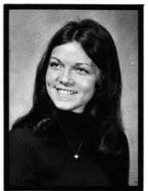

Leslie A. Good

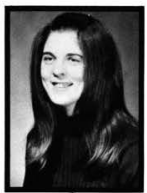

Jan M. Hallet

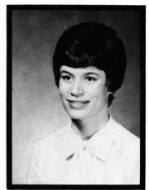

Virginia L. Heal

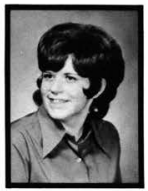

Rosemary Hollingsworth

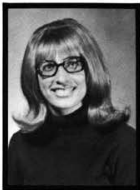

Rita R. Gast

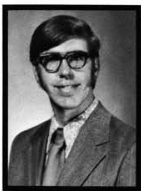

James W. Goodwin

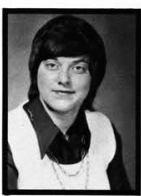

Merla F-Hammack

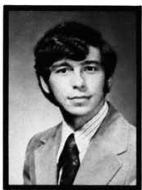

William Henry

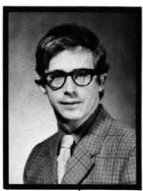

Carl Holz

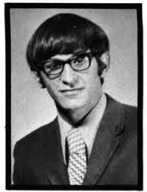

Kim Gerber

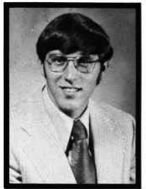

Timothy L. Greenwood

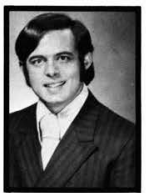

Donald $\mathrm{H}$. Harmon

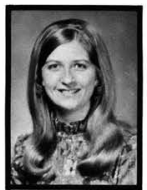

Judith $\mathrm{K}$. Hepworth

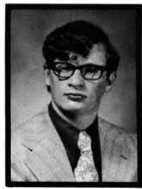

Bernard E. Horn 


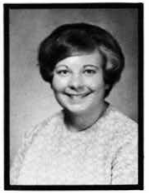

Sharon L. Hothem

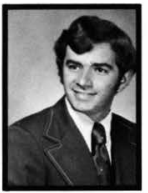

Jonathan $T$. Jenney

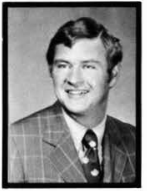

Samuel L. Keifer

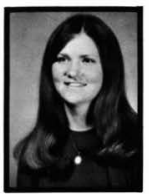

Lois King

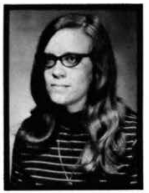

Roberta S. Kohli

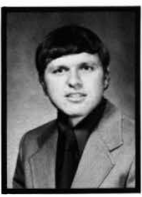

Lynn Howard

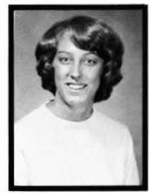

Julianne $E$. Jensen

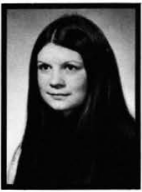

Beverly S. Kemp

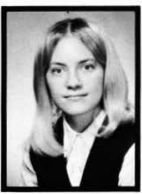

Marquetta F. Kintne:

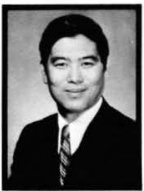

Thomas B.S. Kwak

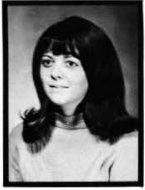

Rebecca S. Howard

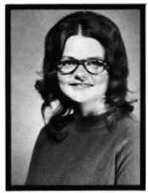

Judy Ann Johnson

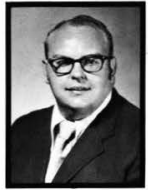

Roy W. Kern

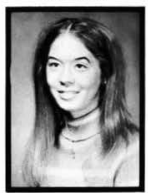

Evelyn Klimek

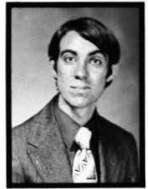

Dana M. Larrick

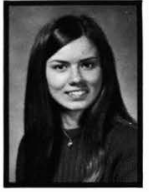

Rosalie V. Howard

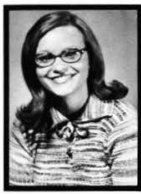

Rhea J. Johnson

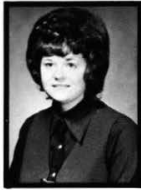

Barbara Johnson Kier

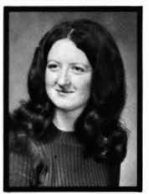

Arlene Knight

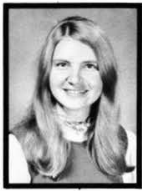

Sally Jo Lemaster

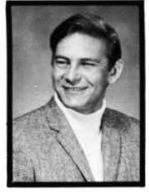

Billy J. Hyatt

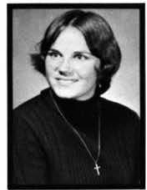

Elaine L. Kalabach

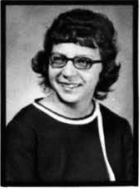

Carole A. Kies

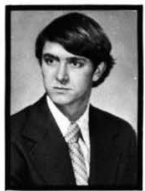

Thomas S. Knowles

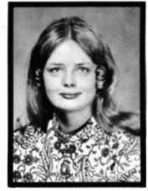

Lorraine Linderman 


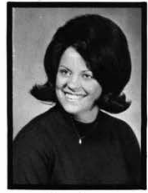

Diane Love

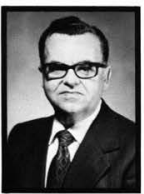

Elvin K. Mattison

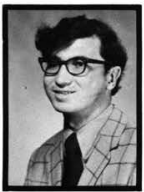

Samuel B. Miller

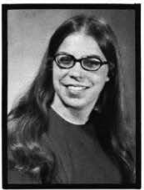

Sharon J. Neeley

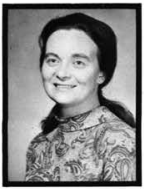

Glenda C. Porter

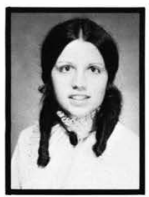

Sylvia Starr Luteri

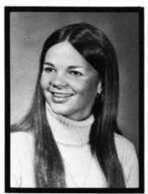

Bonita A. McNeill

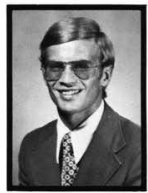

Yontz A. Miller

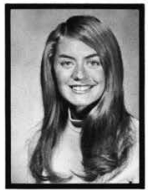

Sharon A. Nerren

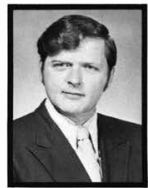

Rodney L. Post

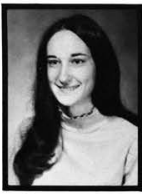

Constance L. Mack

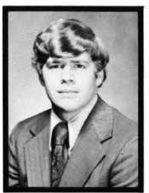

William E. McNiece

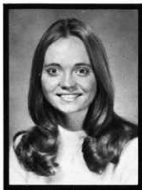

Susan Moore

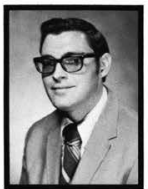

Melvin L. Ness

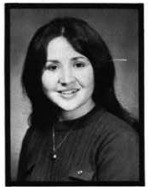

Grace M. Pruden

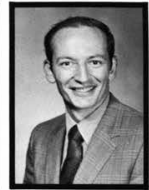

Paul D. Margraff

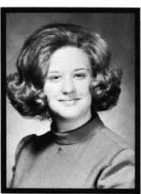

Diane C. Meyers

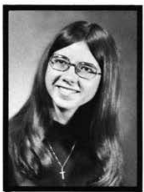

Beverly Morrow

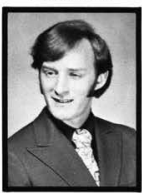

Danny F. Orr

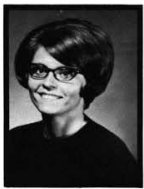

Connie S. Pumpelly

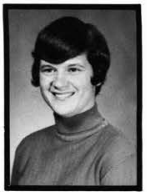

Janice G. Martin

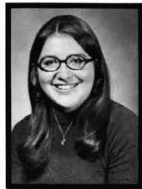

Marilyn K. Milter

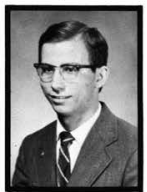

Richard E. Muntis

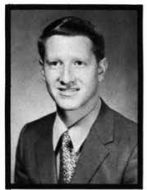

Gene E. Peterson

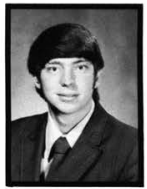

Steve Read 


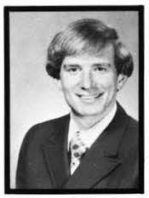

Thomas W. Reeder

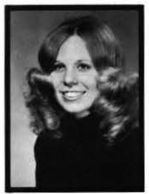

Gale Richardson

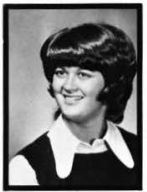

Priscilla Russell

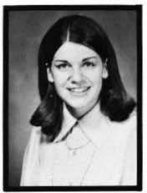

Esther R. Schulz

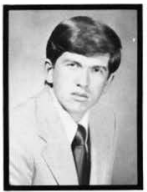

Loren 3 mall

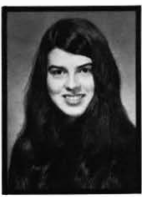

Sharon Reese

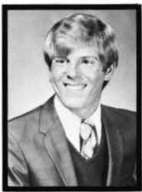

Dennis R. Roberts

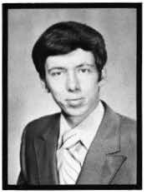

Eidon L. Sarver

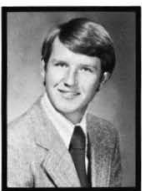

Steven M. Shank

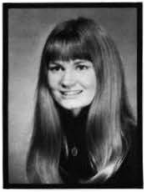

Adria D. Soeder

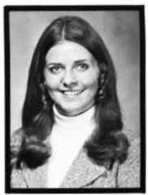

Roxanne Regan

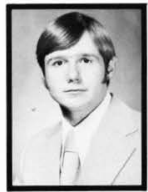

Carl E. Rodgers

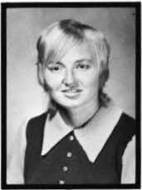

Marsha Sawicki

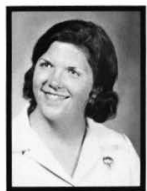

Rachel Shannon

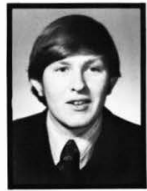

Altred J. Sowards

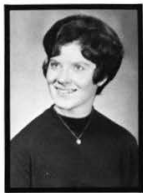

Vicki L. Reynolds

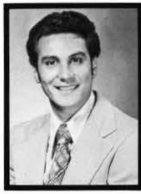

James P. Rosa

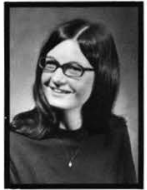

Marion E. Scharmann

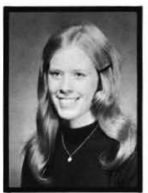

Linda $\mathrm{E}$. Shorey

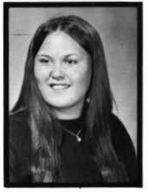

Bonnie Spears

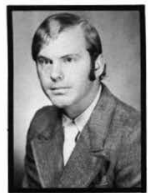

Gerald L. Rice

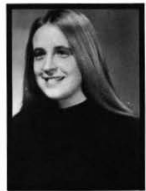

Christine K. Rufener

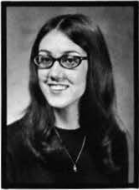

Anita L. Schneider

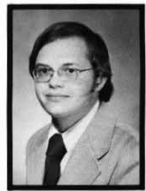

Mark J. Sloan

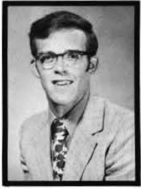

Stephen W. Spink 


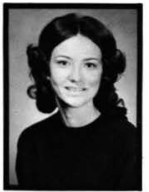

Janice A. Spradlin

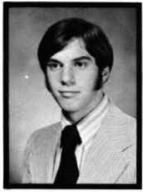

Ronaid Sumner

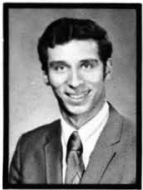

Daniel S. Thompson

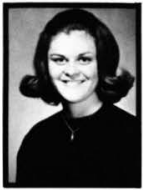

Judith Vine

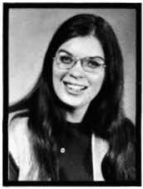

Gabrielle Williams

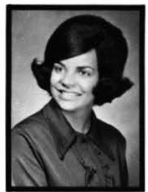

Karen L. Stevenson

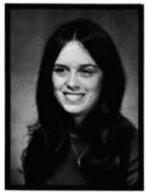

Linda L. Suter

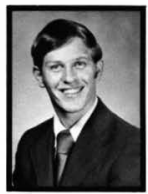

Jacob E. Tipton

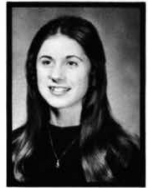

Linda E. Waiter

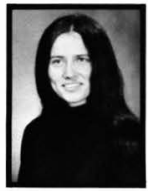

Rebecca J. Williams

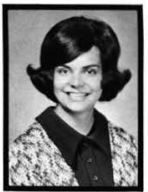

Sharon Stevenson

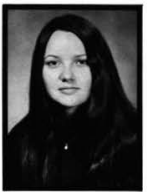

Donita Swisher

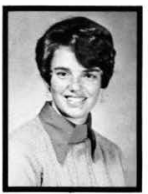

Deborah L. Tobias

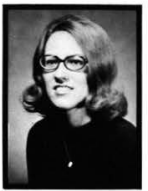

Bette L. Warfield

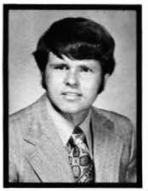

R. Wayne Williams

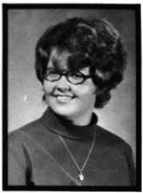

Shirley J. Stoudt

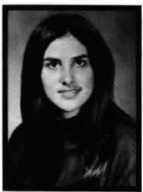

Karen L. Syphers

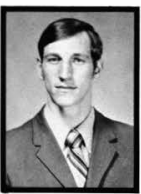

William A, Tobias

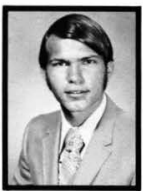

John Weiss

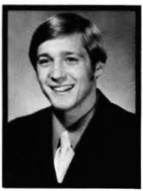

Ronald C. Wita

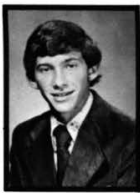

Paul D. Strychalski

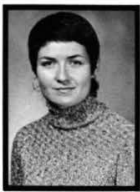

Francine Tarrant

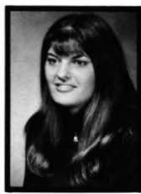

Brenda Tompkins

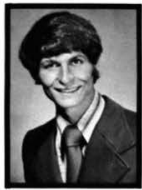

Emest W. Welborn

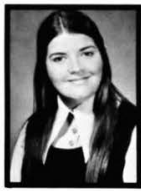

Rebecca L. Wright 
Daniel Adomowich Clay Albertson

Georgeanna Axiotis

Timothy Baker

Dennis Barber

Sharon Bartemus

James Beacham

Bill BeauJean

Ronald Bechtel

Kelsey Bennett

Mark Bohland

Shirley Bohn

Larry Bollback

Gary Brock

Craig Busho

Deborah Byers
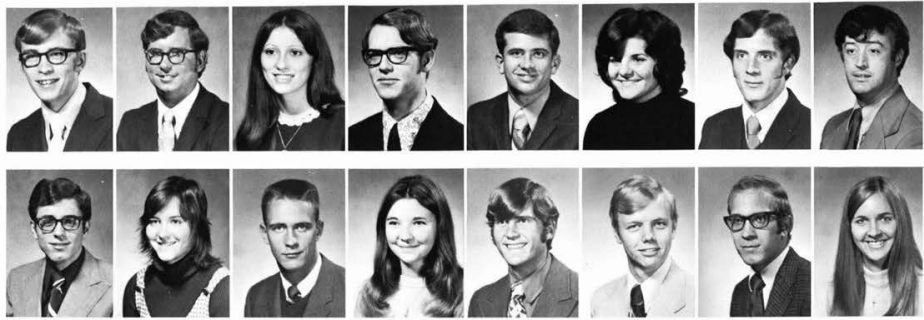

Joleen Byers

Becky Canine

Ken Carlton

Bertha Carter

Randy Clark

Nancy Cleckner

Andy Cole

David Cornoir
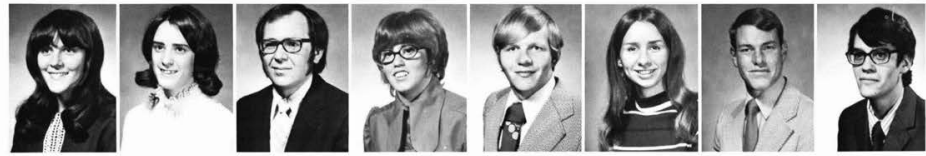

Diane Craig

Sherrill Cressman

Eric Cuenin

Terry Cunigan

Kathy Dalton

Donald F. Davis

Debbie Dear

Joyce DeBruine
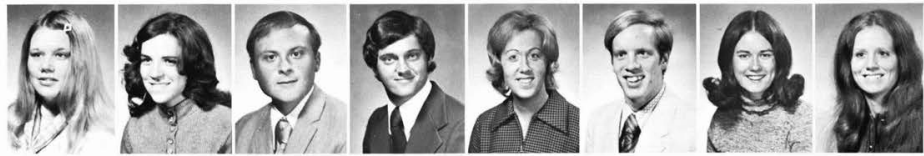

Douglas DeLand Chuck Dolph Diana Douglass

Jane Eberling

Denise Edwards

Linda Edwards

Dan Ehnis

Ruth Emerson
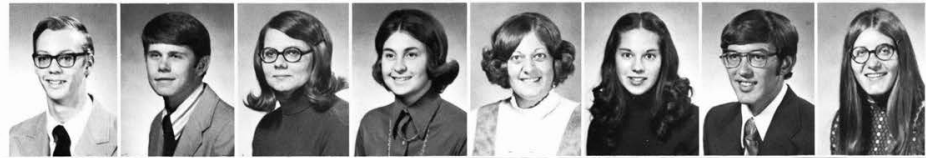


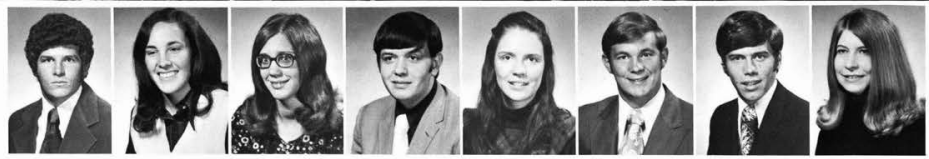

Rodney Hansen Jackie Hargis

Patricia Hickok

Terry Holley

Debbie Holt

Rebecca Holz

Debbie Hostetle

Cheryl Huff
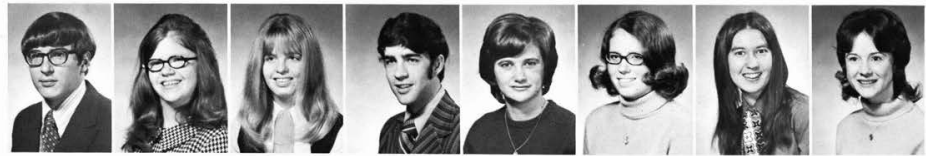

Clyde Hughes

April Jenkins

Holly Jenkin

Darla Jewell

Carol Johnson

Doris Johnson

Pamela Jones

Ronald Jutton
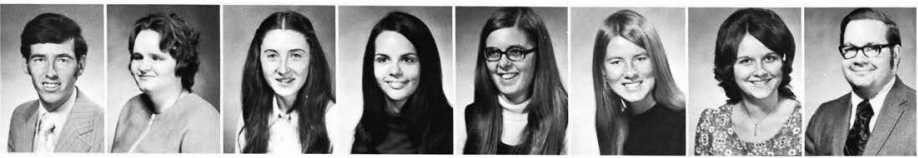

Katherine Karsian

Becky Kemble

Karen Kennedy

Barry King

Jerry Kinniburgh

Linden Kirby

Jeffrey Kistle Bruce Klett
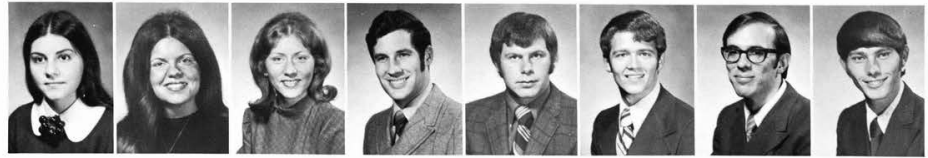

Gary L. Knapp Thomas Kovacik

Steve Lantz

Nanci Layne

Timothy Lee

Monte Leonhart

Nancy Lewright

Dan Lichty
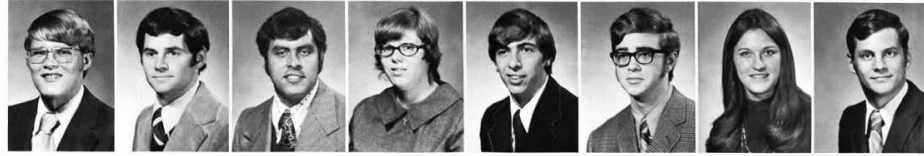
Peter Lillback Mary Lippert Janet Long Dennis Lowstetter Barrett Luketic

Steve McCallister Diana McCarty Bill McCormick

Phil McDonald Don McKanna Bob Mahl

Christine Malernee Linda Maple

Mike Mawhorter Richard Meloy Steve Millikan

Lynn Mitchel Ranelle Nabring Carolyn Newman

David Nicholas

Luann Nicholas

Linda Osborne Bart Otto

Steven Overholt

Clarence Parker Gloria Parker

Linda Pauley

Lucille Perla

Gale Portz

Bill Potter

Richard Profant Bob Pycraft

Cynthia Rathbun David Rodriguez Laura Rodriquez Rex Rogers David Romaine Sally Romanow Richard Rose James Rothberg
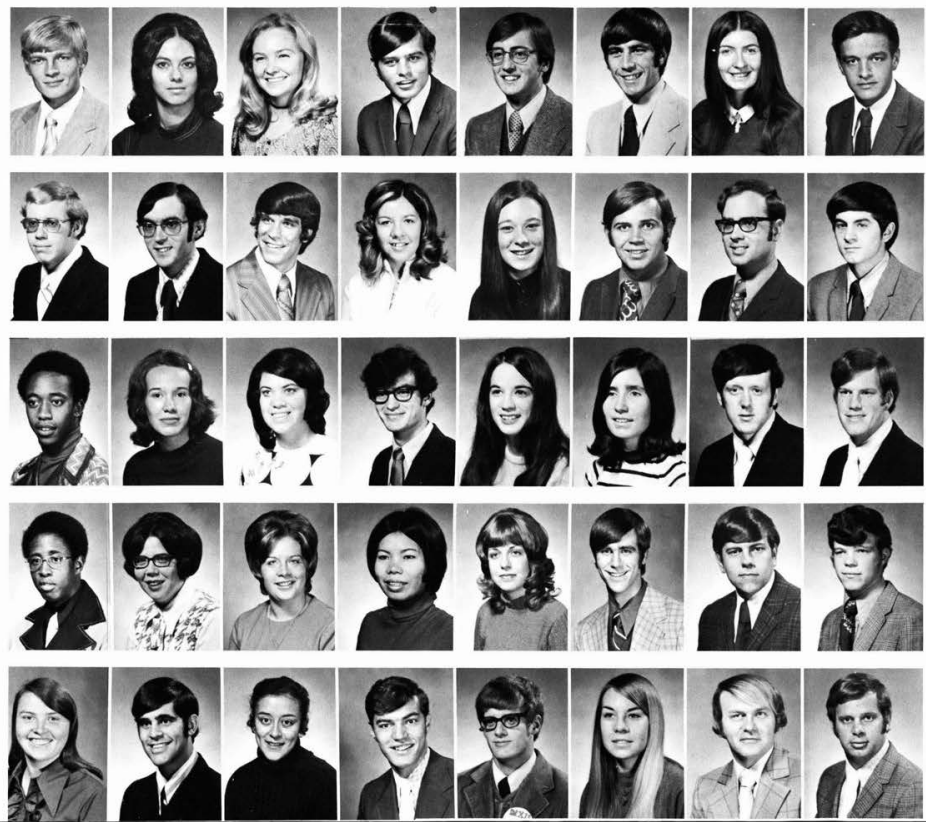
Deborah Samson Kenneth Sanders Cecil Sagraves Donald Schill Ron Schroeder

Renee Seigneur Susan Seldon Linda Severs

Cathy Sharp Richard Shaw

Dean Shugars Kevin Sims

Greg Smith

Steve Smith

Vivian Smith

Fay Solomon

Steve Spencer Jacklyn Spinks Jeff St. Clair Sarah Stone Kathy Strawn Nancy Tallmon Kathy Tompkins David True

Gaylynn Trueblood Dennis Twigg Peggy Wagner Joyce Wall Mary Ann Walker William Washburn Carol Watson Joseph Weah

Greg Webster Claudia Welch Linda White Brenda Will Tom Wineburg Howard Wolff Jeff Wolff Deborah Wood
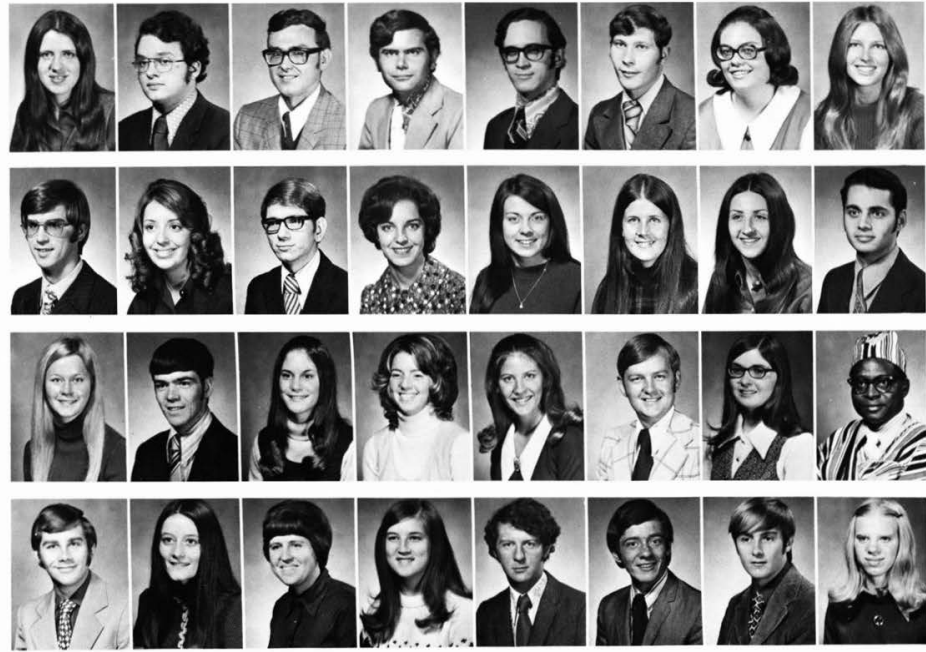

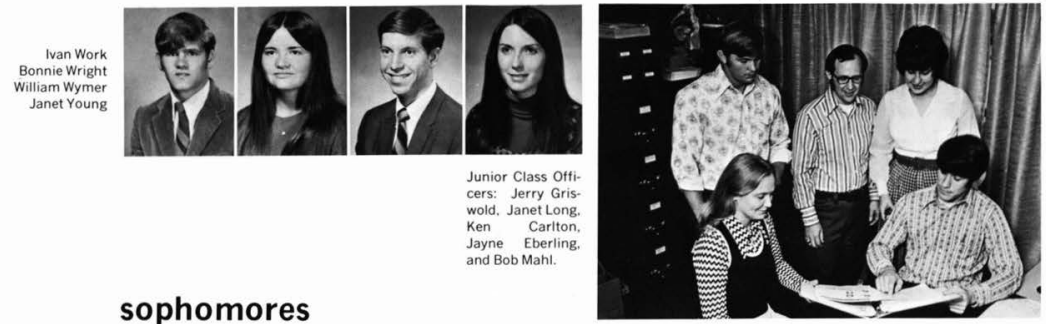

\section{sophomores}
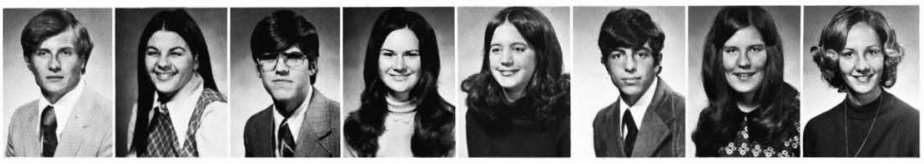

Wayne Aldridge

Tamara Amenold Larry Barnett Kathy Blalock

Debbie Banks

John Battaglia

Marcea Bearss

Nancy Beck
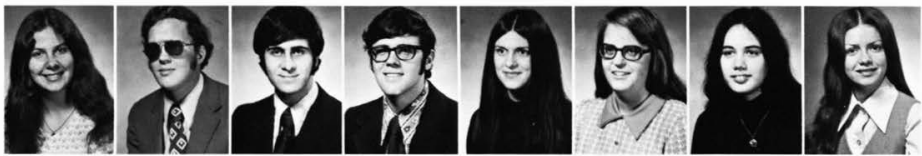

Eva Bennett

Charles Benninger

Dan Bergen

Daniel Bintz

Beverly Boertje

Lorraine Bogert

Carolyn Bonnell

Barbara Bickford
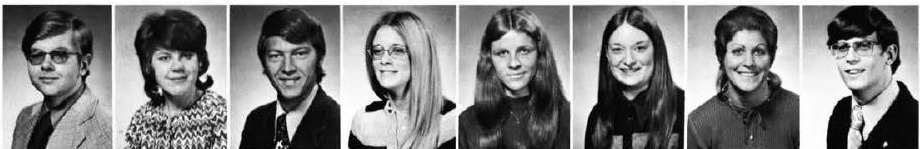

Joe Brooks

Jo Ann Brown

Jack Browning

Evelyn Buckingham

Sharon Byers

Esther Calvin

Barbara Campbell

John Campbell 

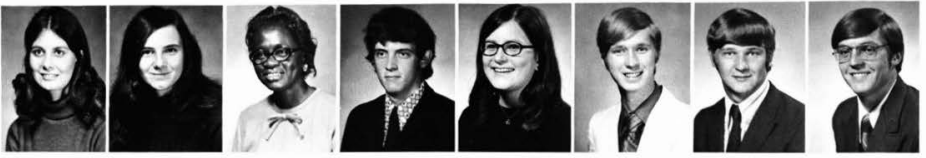

Mary Fink Linda Fisher Irene Ford

Ted Galbreath Peggy Gallogly Dennis George Rick Gerver William Giesman
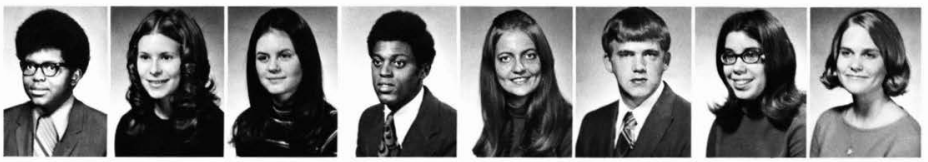

Jerry Gilyard

Mary Glenn

Janet Green

Mark Green

Ruth Gruenberg

Allan Halladay

Sarah Harriman

Carolyn Hayes
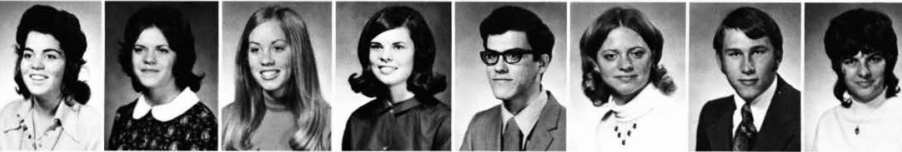

Maria Henriques

Cheryl Heslep

Sandy Hetrick

Bonnie Holder

Ron Hollingsworth

Sandy Holwerda

Thomas Hopewel

Marsha Hosier
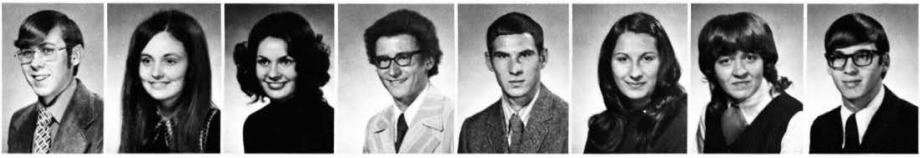

Craig Hughs

Linda Hulsman

Lucy Humphrey Mark Hunter

John Hutchison

Debbie Imbro

Cheryl Jackson

Chris Jackson
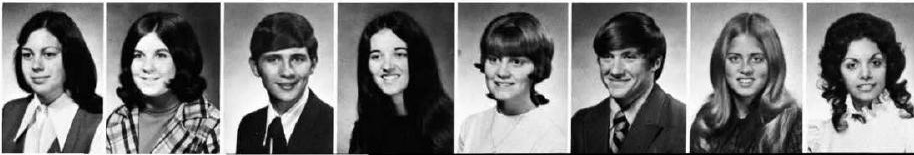

Diane Jacobs Jennifer Jaynes

John Jeffords

Sharon Johns

Brenda Johnson

Don Johnson

Merilee Johnson

Darlene Jones 

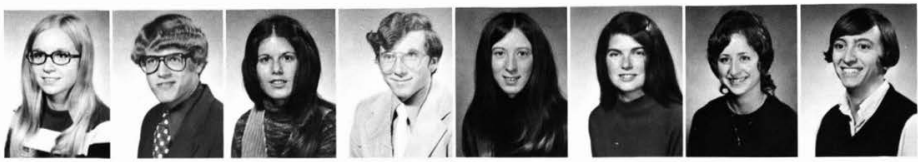

Marguerite Murray

Richard Myers

Marleah Namy

Charles Neuhaus

Patsy Northcutt

Carol Ockert

Jenny O'Neil

Sally Orihood
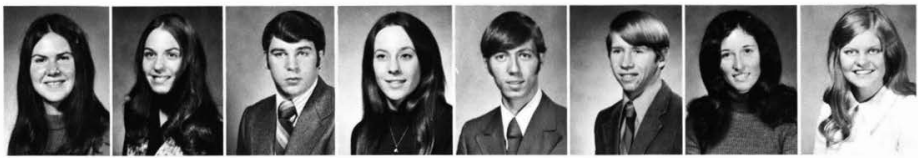

Christine Orton

Kathleen Park

Ted Pauling

Sue Peacock

Harry Phillips

Jacque Poole

Carol Price

Martha Rehn
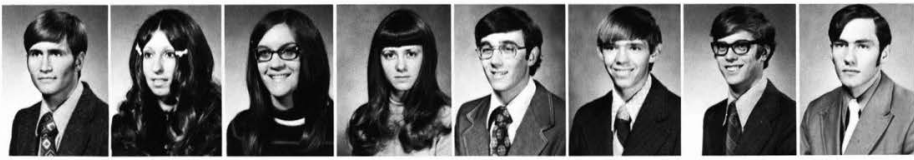

Bill Reno

Cindy Rentas

Holly Rifenberick

Nancy Ritchie

Rod Robison

Randy Rose

Jeffrey Rost

Glenn Rowe
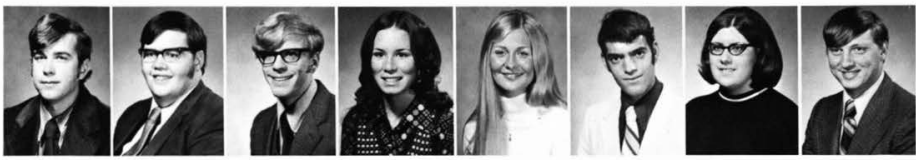

Ronald Rufener

Stephen Russel

Robert Sampson

Cynthia Schlener

Kathy Scott

Wayne Seargent

Janelle Shawver

Steve Sheetz
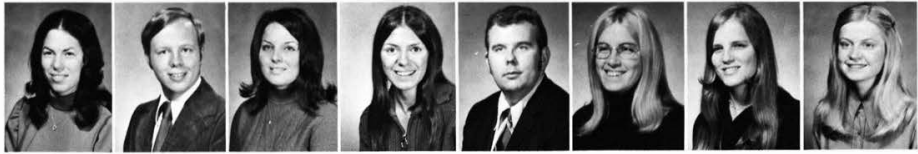

Barbara Shefchik

Steven Skees

Sandra Soliday

Laura Sollenne

David Soule

Debbie Spencer

Ellen Sprague

Sandra Stachler 

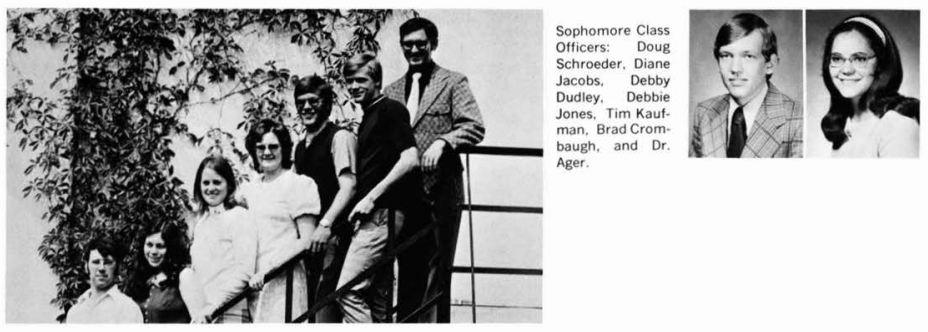

Myron Youngman Beverly Ziegler
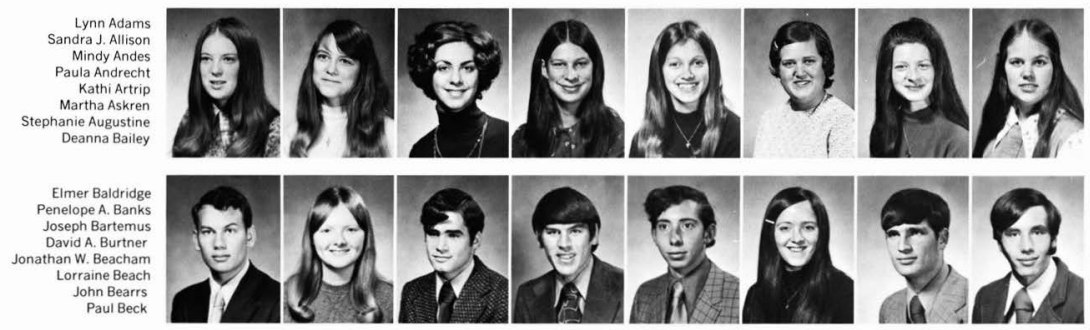

Nova D. Berkenstock Jane Besler Joyce Billington Cindy Bodenmiller Eddie Baggett Martin Book Mitchell Book Jeff Bowen
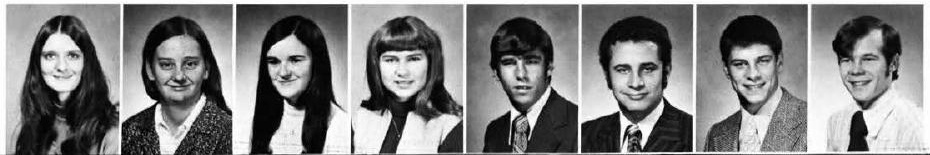
Paul Bowers

Rick Boyer

Marc Bresson

Patty Brewer

Nelson Brinkman

Kevin Brock

Debbie Broughton

Sally Brueser

Timothy A. Buhr Irene Ann Buisch

Bob Burkhart

TerriBussing

Cathy Butler

Sue Ellen Cale

Sandra Cameron

H. Lee Campbell

Pam Campbell Cindy L. Carr

Ruth Ann Chester

Laureen Clark

Russ Clark

Anne Cleckner

Larry Cline

Mike Cobine

Carl Cook Thomas Cook Dan Coomes

Mary Jane Cooper

Ralph Cornwell

Steve Costley

Linda Couch

Cheryl Cowen

Cindy Cox

James Cunagin

Linda Cupan

Kathy Curtis

Donald Criss

Paul Crittenden

Deborah Davis

Rick D. Deal
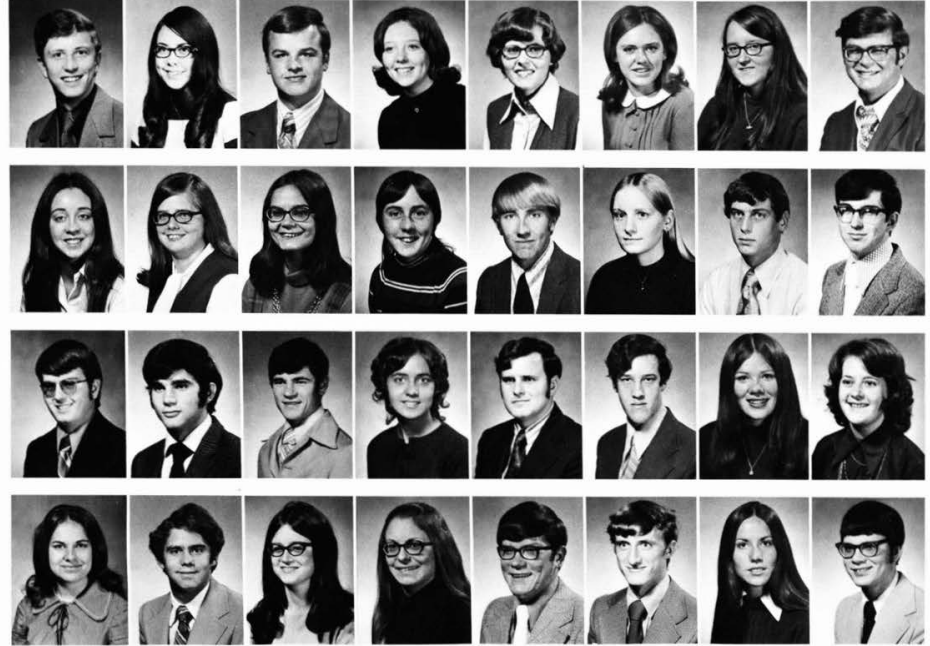
Darryl DeClute

Dave DeLancey

Dana DePriest

Paul DeRoin

Henry Diaz III

Janice Dixon

Catherine Dubois

Sharolyn Eley

Mark Ernhart Wesley Fairchild Kevin Fields

Robert Fisher

Sharon Franks

David Frederich

Pam Funderburg Leslie M. Gaippe

Susan Gale Lyman Gantz Susan Gazdik Danny Gillette Carol Gilmour

Timothy L. Gabler Debbie Good Gary Gossett

Cheryl Griffis Mary Griffith Carolyn Grollimund Kevin Gruber Debra Hackworth Delmar Hager James Halladay Robert Hammond

Nancy Hare Frank Hariman Barbara Harris Hope Harris Sue Harris

Karen Hauser James Hawbaker Randy Hay
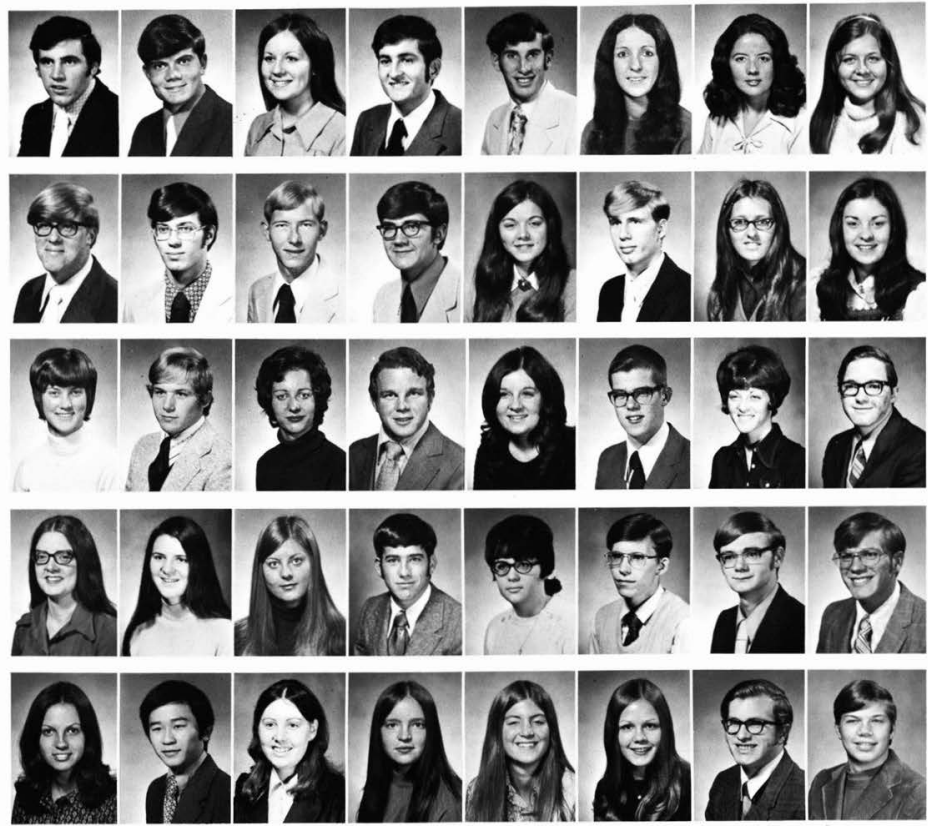
Randy Helmick Kathy Hepworth

Linda Herrin

Dave Hickey

Douglas Hilleary

Becki Hilton

Dan Himsel

Linda Hinds

Jim Hintz
Susie Hogsett
Valerie Hook
Michael Horton
Marcia Houck
Christine Howard
Jerry Howdyshell
Terry Howdyshell

Mike Hunting Mike Jason

Christine Johnson

Dale Johnson

David Johnston

Richard Johnson

Daniel Jones

Mark Judkins

Susan Kempf
Pete Kendrick
Shelley Knowles
Nancy Lampiris
Kirby Lancaster
Kevin Landis
Zita Leapline
Daniel Leatherman

Cyndie Leighton

Melinda Litifin

Bobbie Litts

Noreen Lyon

Jess Mann

Deitra Marshall

Carol Martin

Kirk Martin
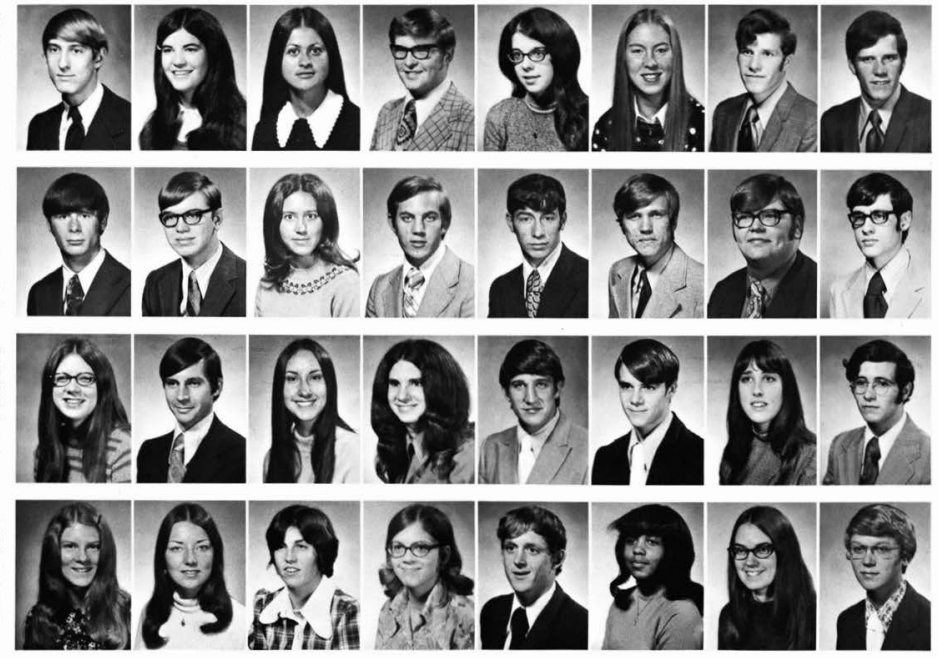

freshman/203 

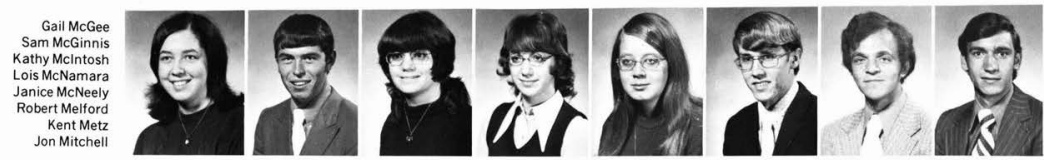

Nancy Moffit

Wendy Montgomery

Pamela J. Mooney

Ray Moore

Kurt Moreland

Karen Namy

Patricia Neely

William Nickel
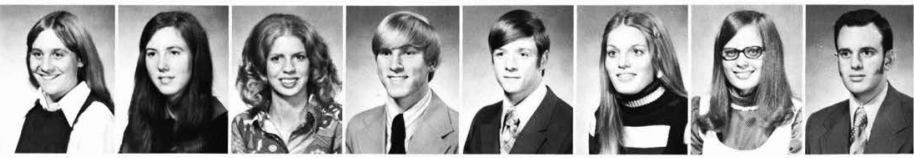

Michael Niles

Jonathan OIsen

Sally O'Shell

Ann Orwick

Gerald Perry

Leona Perry

David Perryman

Linda Peterson
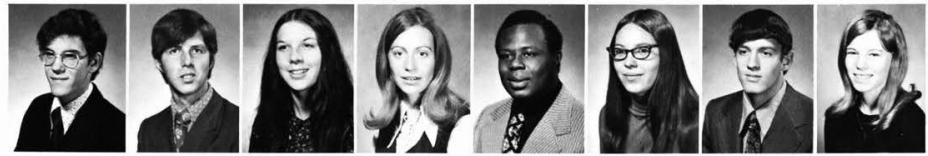

Pamela Phelps

Carol Phillips

Mary Potter

Mary Pruden

Harold Pulver

Dan Pycraft

Tom Pycraft

Steve Read
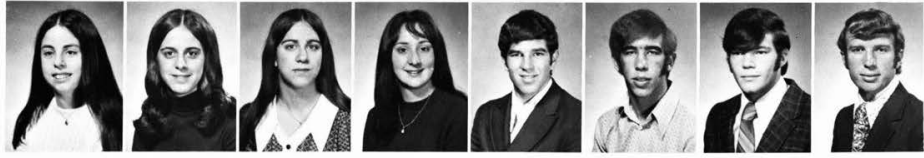

Donald Reed

Brian Reese

Kent Richards

Curt Riess

Sue Rinehart

Patty Ritchie

Dawna Robb

Rodney Robertson
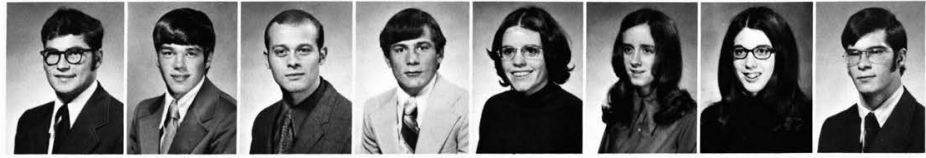


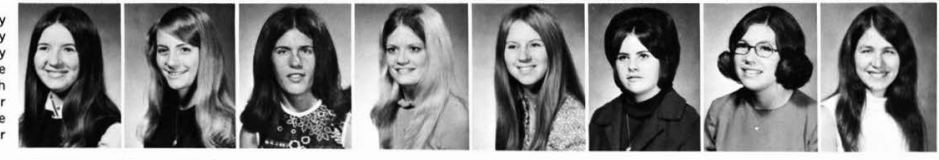

$$
\begin{array}{r}
\text { Janice Slade } \\
\text { Sue Slocum } \\
\text { Dave Slusher } \\
\text { Maynard A. Smart } \\
\text { Carol Smith } \\
\text { Jim Smith } \\
\text { Patricia G. Smith } \\
\text { Patricia Smith }
\end{array}
$$

Terri Smith
Cathie Snoke
Tony Solomon
Frank Soper
Ellen Spaulding
Sue Stauffer
Karen Steenburg
Jon Steinhaven
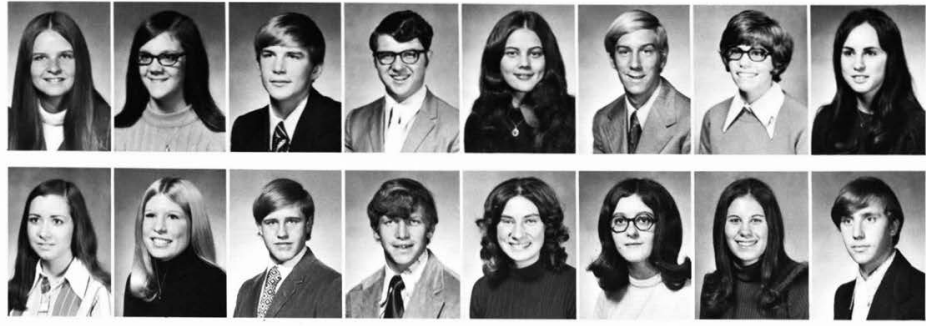

Connie Stoltzfus
Lewis Stone Lewis Stone John Street

Kevin Swineford

Carol Symonds

Becky Tallman

Nancy Taylor Becky Tazelaar
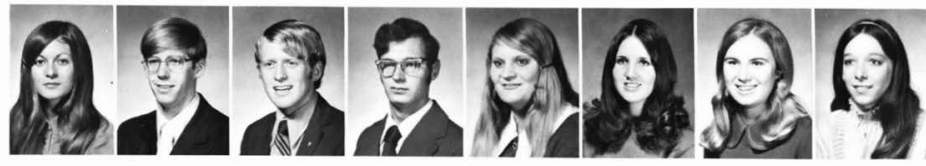

Ruth Teed

Peg Temple

Sheryl Theetge

Margaret Thomas

David Tink

Gary Tolle

Angel Torres

Gary Trittipoe
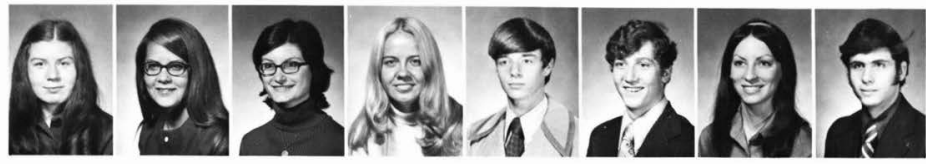


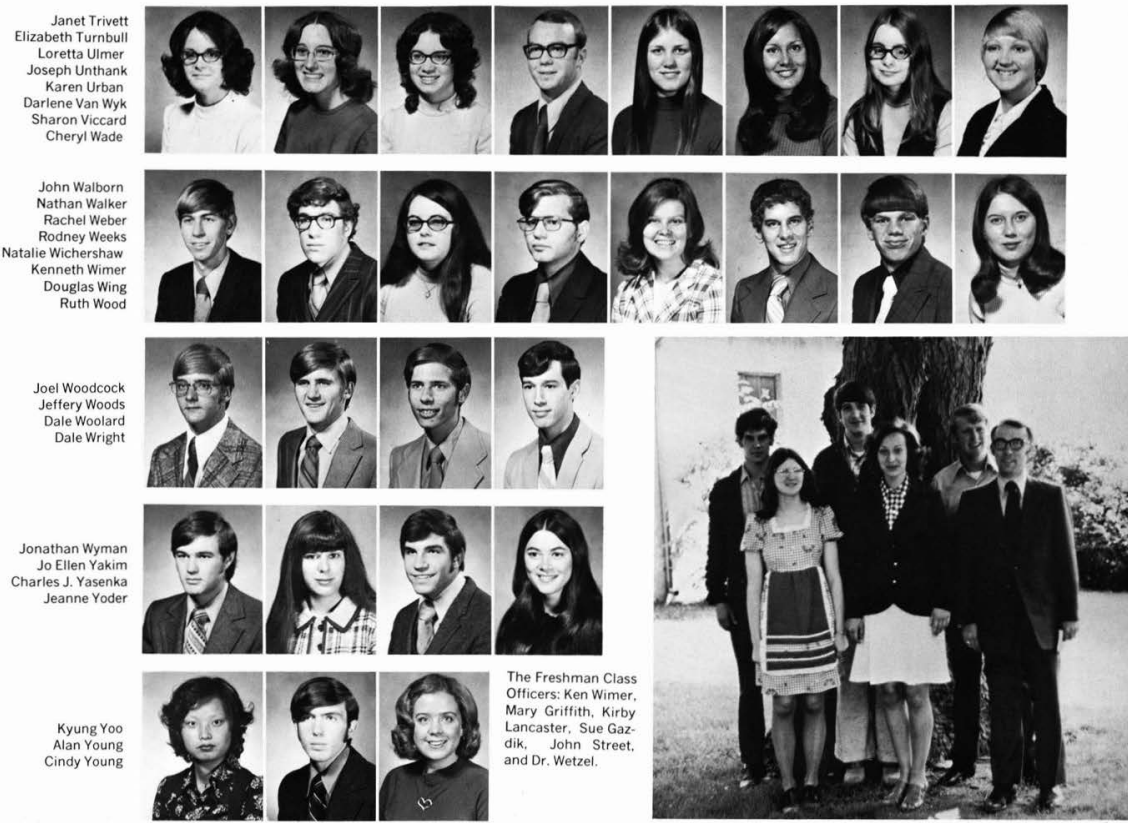


advertisements 


\section{FIRST BAPTIST CHURCH}

114 South Maple, Pana, Illinois

Gerald Thurber, Pastor

\section{Dayton and Southeastern Lines Inc.}

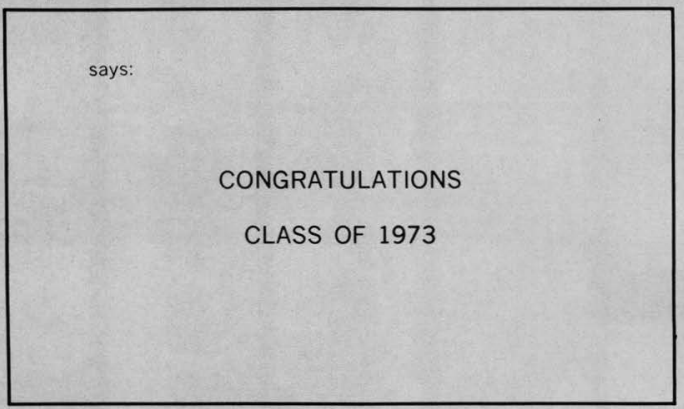

Charter Service in U.S.A. and Canada PHONE:
$1 \mathrm{E}$. Washington St.
Jamestown, 0 .
513-675-4301

\section{CALVARY BAPTIST CHURCH}

Depot Rd. and Maple Dr. Salem, Ohio Fred W. Robb, Pastor

PHONE: 337-6759

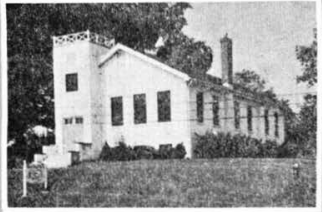




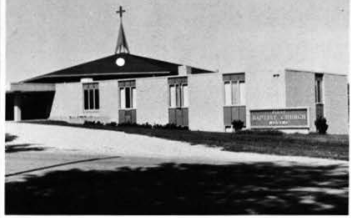

FIRST BAPTIST CHURCH

1001 N. Lincoln

Creston, lowa

Norman E. Hoag, Pastor

STUDENTS AT CEDARVILLE:
Nancy Tallmon

Rebecca Talimon
Carol Johnson

Paul Crittenden

\section{CRITERION}

Xenia, Ohio

MEN'S CLOTHING AND

FURNISHINGS

VARSITY TOWN - ARROW

MCGREGOR - PALM BEACH

\section{FIRST BAPTIST CHURCH}

\section{OF SILVUS, ILLINOIS}

"The All Family Church"

11019 th Ave.

John Lineberry. Pastor

"The Lord's Choicest Blessings Upon You Graduates"

\section{THE CAMERA SHOP}

34 WEST MAIN ST.

Xenia, Ohio

Phone 372-1469

\section{BETHEL BAPTIST CHURCH}

1704 Springdale Rd.

Chenny Hill, N.J.

Dr. Carl Elgena.

Pastor

Congratulations

to the

Class of 73
PARENT PATRONS

Mr. \& Mrs. Frank Andrecht Evansville, Indiana Mr. \& Mrs. Neil Augustine

Greenville, Ohio

Mrs. M.E. Beck

Harvey, lllinois

Mr. \& Mrs, Harold J. Benninger

Linkhannock, Pa.

Dale Bintz

Vineland, N.J.

Mr. \& Mrs. Richard L. Bogert Corry, Po.

Mr. \& Mrs. Paul L Book

Slippery Rock. Pa.

Mr. \& Mrs. Clarence W. Brueser

Youngstown, Ohio

Mr. \& Mrs. Floyd Burtner Lebanon, Indiana

Mr. \& Mrs, George W. Cale

Ponce Puerto

Mr. \& Mrs. S.M. Conrad

Akron, Ohio

Mr. \& Mrs. Richard N. Cook Mulliken, Mich.

Rev. \& Mrs. Douglas Couch Victoria, Australia

Rev. \& Mrs. James Crady

Springtieid, III.

Carl K. Craig

Springtield, Ohio

Lester Cressman

Delphos, Ohio

Mr. \& Mrs. Clifford Criss

Mansfield, Ohio 


\section{FIRST \\ BAPTIST CHURCH}

\author{
125 GRAND AVE. \\ WELLINGTON, OHIO \\ PASTOR, CHARLES RUGG
}

PHONE: 647-2477

PARENT PATRONS

Mrs. F W. Cittenden

Creston. lowa

C. Cronbaugh

Kent, Ohio

Mr. \& Mrs. Robert P. Cuenin

Amherst, Ohio

Mr. \& Mrs James Cunagin

Ludiow Falls, Ohio

Pastor 8 Mrs. Floyd A, Davis

Shawnee Mission, Kansas

Mr. \& Mrs. Raymond Davis

Sherman, N.Y.

Mrs. Mayme Deal

Springfield, Ohio

Mr. \&Mrs. Richard V. Dear

Saxonburg, $\mathrm{Pa}$

Mrs, Irene Dedrick

Dryden. N.Y.

Dr. \& Mrs. Donaid DeLancey

Perkasie, Pa

Mr. \& Mrs. Eugene DeLand

Dresden, N.Y

Rev. \& Mrs, James $F$, Dersham

Elyria, Ohio

Robert L. Dixon

Coolville, Ohio

Mr. \& Mrs. Charles E. Dolph

Bellefontaine, Ohio

Mr. \& Mrs, John Ediund

Harvey, III

Mr. \& Mrs. Lyie Edwards

Bolivar, N.Y

Mr. \& Mrs, LeRoy Ehnis

Brooklyn, Mich.
Mr. \& Mrs. I.L. Ellis

Arlington, $V_{3}$.

Rev. \& Mrs. Eugene Ellison

Battle Creek. Mich.

Mr. \& Mrs. Merlyn Emerson Prattsburg. N.Y.

Mr. \& Mrs Jack Erickson

Hobart, Ind.

Waiter \& Joyce Erickson

Paimer, Mass.

Mr. \& Mrs. Fair Sr

Lebanon, Ohio

Mr. \& Mrs. Dale Fariow

Camp Point, IIt.

Mrs. Earl Farmer

Mantor. Ohio

Mr. \& Mrs. Duane Frederick

Tonawanda, N.Y

Mrs. C.G. Gaippe

Parma, Ohio

Mr \& Mrs. Richard Gerber

Berlin, Ohio

Mr. \& Mrs. Harold Gillogly

Newport, Mich

Mr. \& Mrs. William Gilmour

Niles, Ohio

Mr. \& Mrs. Clair A. Glenn

Butler, $\mathrm{Pa}$.

James \& Helen Gossett

Akron, Ohio

Mr. 8 Mrs. Ed Gruber

Greenvilie, Onio

Homer Hale

East Alton, III.

\section{COUNTY LINE BAPTIST CHURCH}

\section{Calvary Baptist Church}

\section{Cresaptown, Maryland}

"For the Word of God and the testimony of Jesus Christ"

Rev. Roger A. Mills

$$
\text { P.O. Box } 5154
$$

Cresaptown, Md.
2234 County Line Rd.

Dayton, Ohio 45430

"HOLDING FORTH THE WORD OF LIFE ...."

PHIL. 2:16

"A Friendly Church with an Eternal Message" 


\section{Baptist}

\section{Bible}

\section{School}

of

\section{Theology ${ }^{\text {* }}$}

BEFORE YOU SPEND A LOT

OF TIME AND MONEY FOR

GRADUATE STUDY IN THEOLOGY,

* The east coast's only G.A.R.B.C. postbaccalaureate school of theology.

YOU SHOULD KNOW WHAT YOU

ARE BUYING.

AT B.B.S.T, YOU WON'T GET

A REHASH OF YOUR UNDER-

GRADUATE BIBLE COLLEGE

COURSES - EVEN IF YOU

HAVE MAJORED IN BIBLE AND

THEOLOGY!

WRITE FOR CURRENT CATALOG:

DIRECTOR

Baptist Bible School of Theology

538 Venard Road

Clarks Summit, Penna. 18411

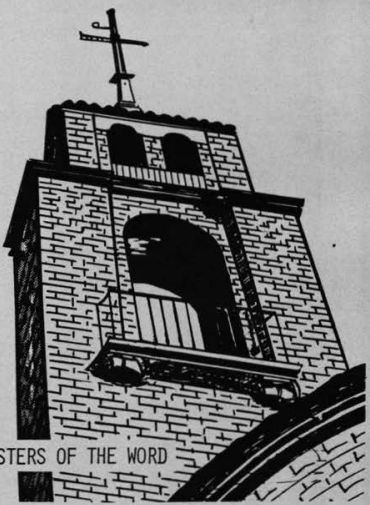




\section{BLESSED HOPE BAPTIST CHURCH}

315 South Kensington Place

(one block off North Limestone, Route 72)

Springfield, Ohio 45503

JOSEPH C. CHAPMAN, PASTOR

Welcome to all students and graduates

The friendly church with a vision

"Holding forth the Word of Life" (Philippians 2:16)

Congratulations Class of 1973

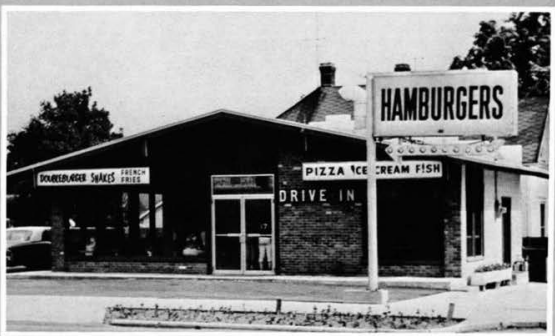

Little Joe's In Cedarville - just for you 


\title{
CALVARY BAPTIST CHURCH
}

\author{
Box 25 St. Charles, lowa
}

Best Wishes to the Class of 1973

\section{Cedarville Federal Savings \& Loan Association}

\author{
Telephone $513-766-2141$ \\ Cedarville, Ohio 45314
}

$5 \%$ PAID ON PASSBOOK ACCOUNTS

\section{FIRST BAPTIST CHURCH}

\author{
Sherman, New York
}

"Set for the Defense and Propagation of the Gospel of Jesus Christ"

In fellowship with G.A.R.B.C. A.C.C.C.

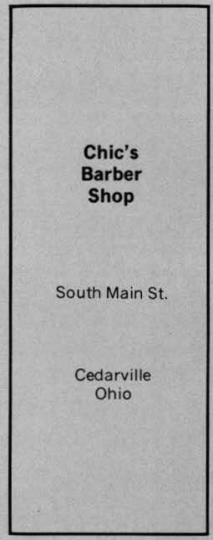

\section{PARENT PATRONS}

Mr. \& Mrs. Robert Hallett Conneaut, Onio.

Mr. \& Mrs. Richard Hamilton Michigan City. Ind.

Dr. \& Mrs. W.M. Hammack

Niles, Ohio

Mr. \& Mrs. Leroy Hansen

Mt. Pleasant. Mich.

Mr: a Mrs. Ken Harris

Dayton, Ohio

Mr. \& Mrs. Harold E. Harrison

Deal, New Jersey

Mr. \& Mrs. Henry Hauser

Berea, Onio

Rev. \& Mrs. Everett Hawbaker Lombard, ill.

Wayne Heal

Bunker Hill, III.

Karl Helmick

Traverse City. Mich.

James Hetrick

Tonawanda, N.Y.

Mr. \& Mrs. Leonard Hickey

Hobart. Ind.

Mr. $\&$ Mrs. James Himsel

Oak Creek. Wisc.

Mr. \& Mrs Eldred Hinds

Montrose. Pa.

Mr. \& Mrs. Oliver Holden

DeLand, Florida

Mr. \& Mrs. Thomas Holley

Twinsburg. Ohio

Mr. \& Mrs. Harold Holz

Linden, Mich. 


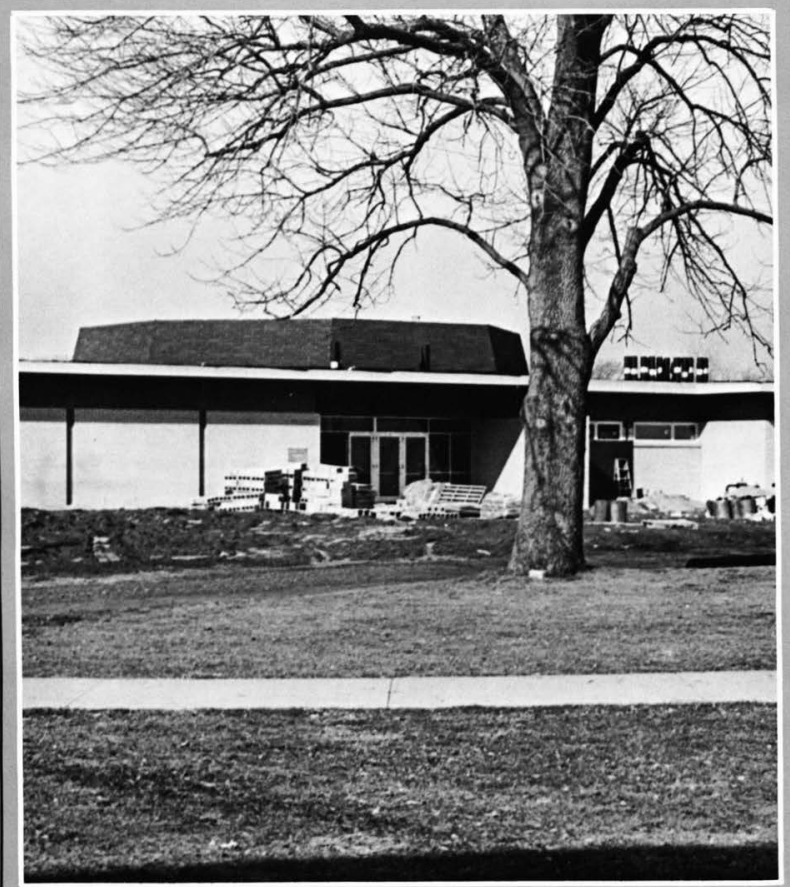

\section{WENDRICK CONSTRUCTION CO.}

Medway, Ohio 


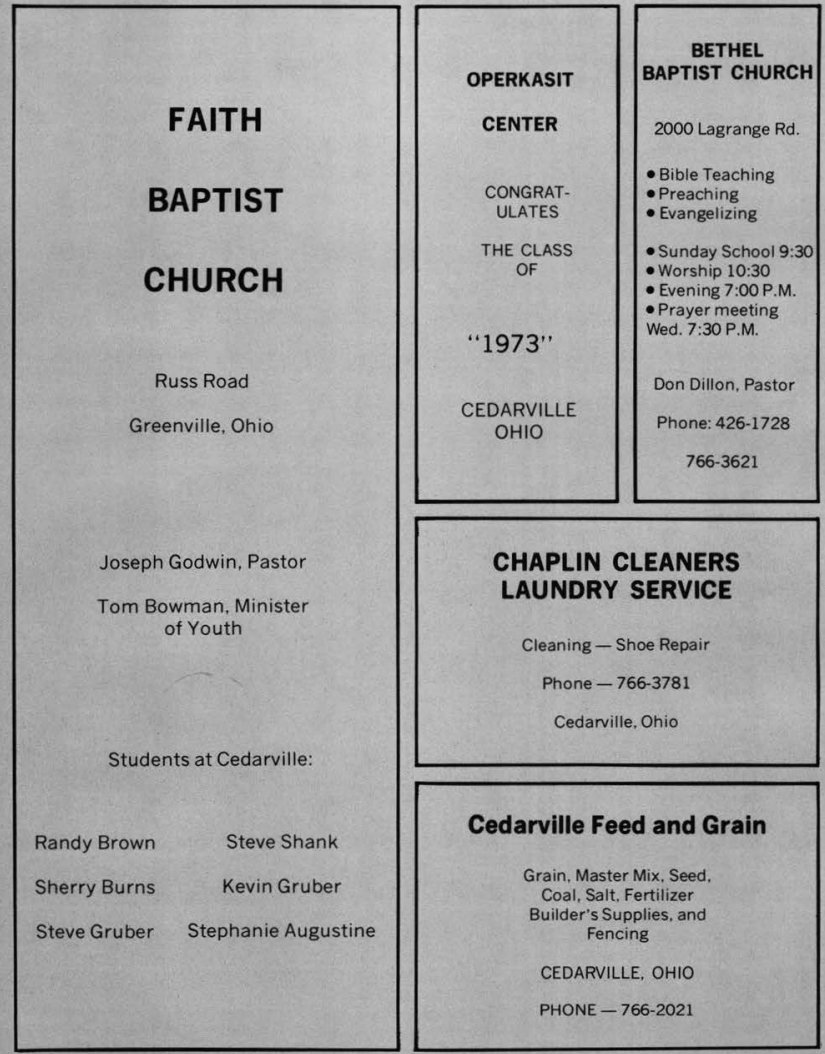




\section{WALNUT CREEK BAPTIST CHURCH}

P.O. Box 123

Baltimore, Ohio

D.D. Canterberry, Pastor

"Behold, now is the accepted time: behold, now is the day of salvation." II Cor. $6: 2$

\section{Clifton "72" Market and Sunoco}

St. Route $72-343$ Clifton, 0.

"Clifton's Largest"

Congratulations Class of 1973

\section{Hilltop Sunoco, Cedarville}
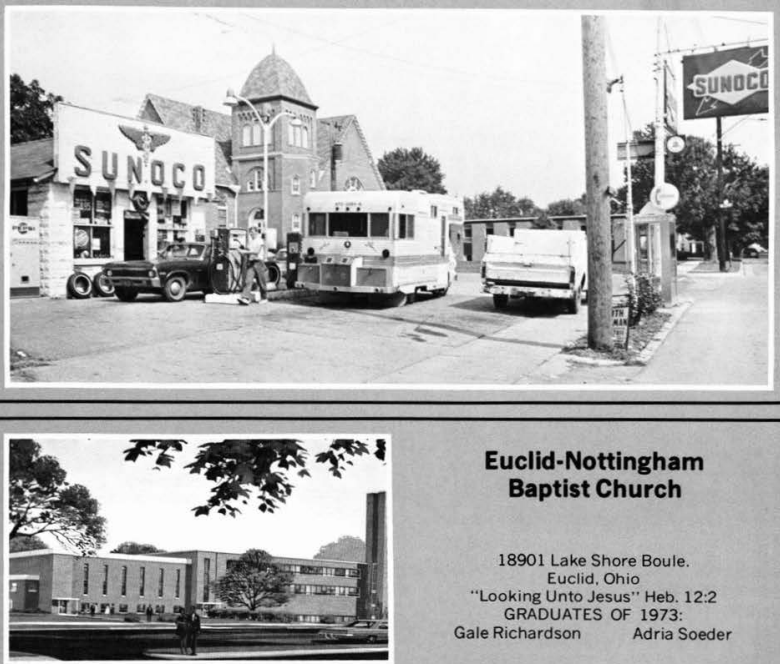

\section{Euclid-Nottingham Baptist Church}

18901 Lake Shore Boule.

Euclid, Ohio

"Looking Unto Jesus" Heb. 12:2

GRADUATES OF 1973:

Gale Richardson 


\section{Congratulations to the}

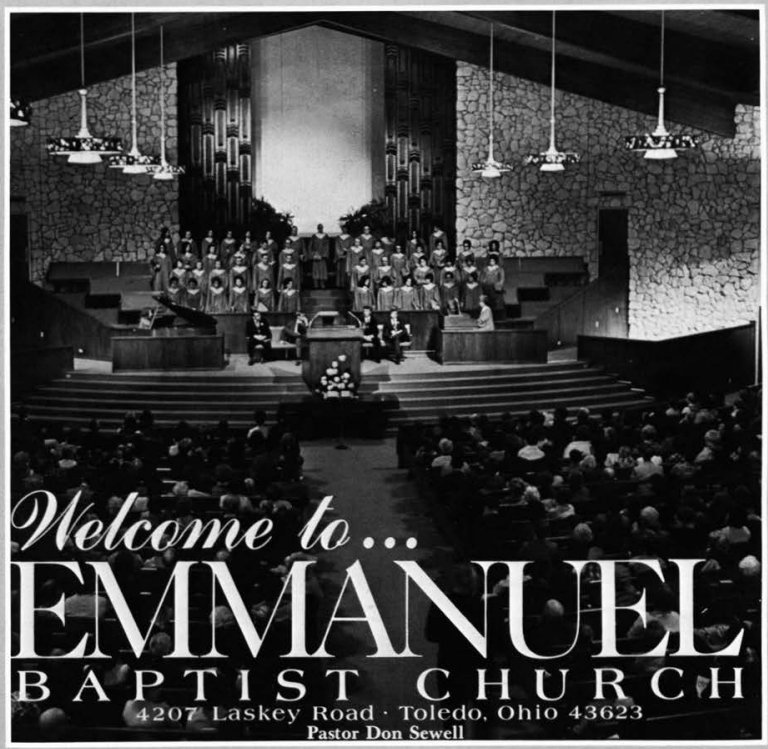

\section{class of 1973}




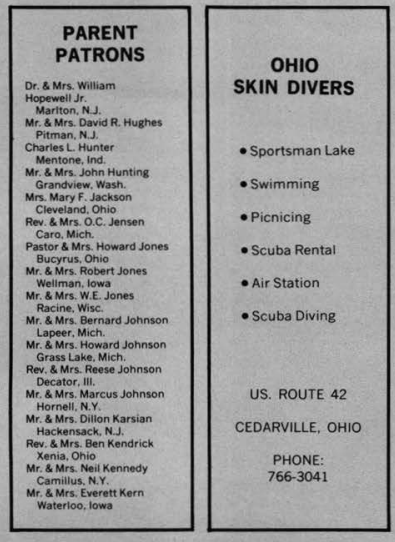

Dr. \& Mrs. William

Hopewell $J r$.

Mariton, N.J.

Hunting

Cleveland Ohio

Caro, Mich.

Pastor \& Mrs. Howard Jones

Weliman Iowa

Mr. \& Mrs. Bernard Johnson

Grass Lake. Mich.

arcus Johnson

Hackensack, N.J

Mr. \&. Mrs. Neil Kennedy

rett Kern

Waterioo, lows

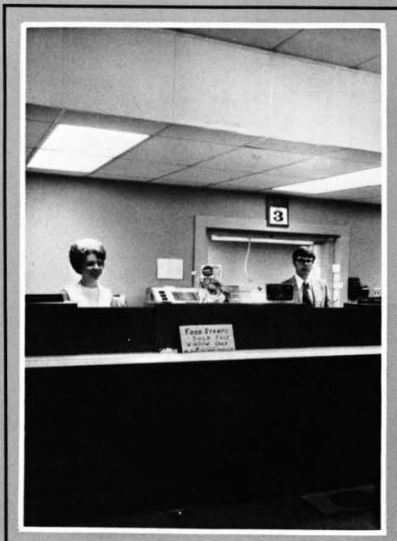

\section{MIAMI DEPOSIT}

\section{BANK}

\section{DRESSERVILLE BIBLE BAPTIST CHURCH}

\author{
New York
}

R. Craig Golden, Pastor

Home church of Bill Bacheller

- President of the Graduating Class

\author{
"Here to Serve You" \\ MEMBER OF F.D.I.C. \\ CEDARVILLE, OHIO \\ YELLOW SPRINGS. OHIO
}

PHONE: 766-3611 
HALL OF FABRICS

CEDARVILLE, OHIO

PHONE:

\section{WHEELERSBURG BAPTIST CHURCH}

Gallia at South Streets

P.O. Box 224

Wheelersburg, Ohio

Robert W. Teis Jr.,

Minister of Education and Youth

STUDENT AT CEDARVILLE:

Chrys Martin

\section{FIRST BAPTIST CHURCH}

\section{"Preaching peace by Jesus Christ:}

He is Lord of all." Acts 10:36

Sunset Road, East of Willingboro Pkw.

Willingboro, New Jersey

Rev. Gerald Montgomery, Pastor
(1)

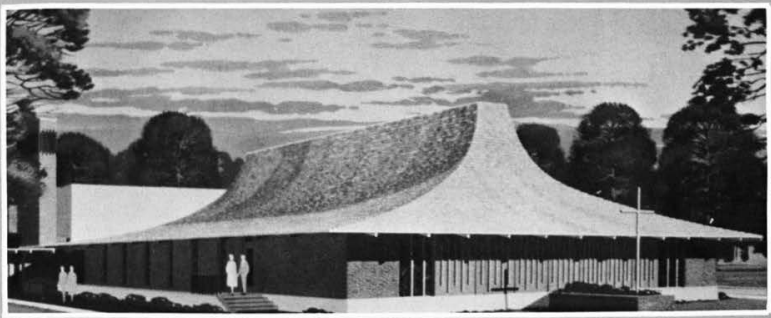

\section{BEREA BAPTIST CHURCH}

Congratulations Seniors!

You are invited to attend Berea

Baptist Church, 250 West St. Berea, O.
Roy Gibbs, Pastor Roger Salomon, Dir. of Ch. Ed.

Bible School 9:30 a.m. Worship Service 10:45 a.m. Evening Service 7:00 p.m. 


\section{The Hornell Gospel Center}

\author{
1 Main Street
}

Hornell, New York

STEWART L. BRADY, PASTOR

Philippians 4:13

\section{Flowers by lona}

34 MAIN ST.

CEDARVILLE, OHIO

Flowers and Gifts

Ceramics and Greenware

Phone - 766-5768
FIRST

BAPTIST

CHURCH

Newark Valley New York

Gordon Lewis

Pastor

\section{STUDENT AT}

CEDARVILLE

Marguerite Murray
PARENT

PATRONS

Mr. \& Mrs. William Kesler Oiney, III.

Mr. \& Mrs. Joseph Klimek

N. Jackson, Ohio

Mr. \& Mrs. Edward Kinzig

Dayton, Ohio

Mr. \& Mrs. Vincent Lake

Atlantic City, N.J.

Mr \& mrs. Andrew Lampiris

Sault Ste. Marie, Mich.

Dr. \& Mrs. R.K. Lancaster

Batavia, Ohio

Mr. \& Mrs. Delbert Lantz

indianapolis, Ind

Mrs. Irene Leapline

Dunbar, Pa.

Mrs. Ray Leatherman

Lorain, Ohio

A.L. Lewright Ir.

Eagle Grove, towa

Eagle Grove, lowa

Frances Lippert
Franktin Grove. III.

Mr. \& Mrs. Buchard Lyon

Sherman, N.Y.

Jacob \& Mary Lee Mack Anderson, Calif.

Mr. \& Mrs. Vincent Mahl

LaGrange, Ohio

Mr. \& Mrs. William T. Mapel

Lima. Ohio

Mr. \& Mrs Olan Martin

Mr. \& Mrs. Olan
Bronson. Mich.

Rev. \& Mrs. Billic McCarty

Canfield, Onio

\title{
FIDELITY UNION LIFE INS. COMPANY
}

\author{
1132 BROWN STREET
}

DAYTON OHIO

CONGRATULATIONS CLASS OF 1973 


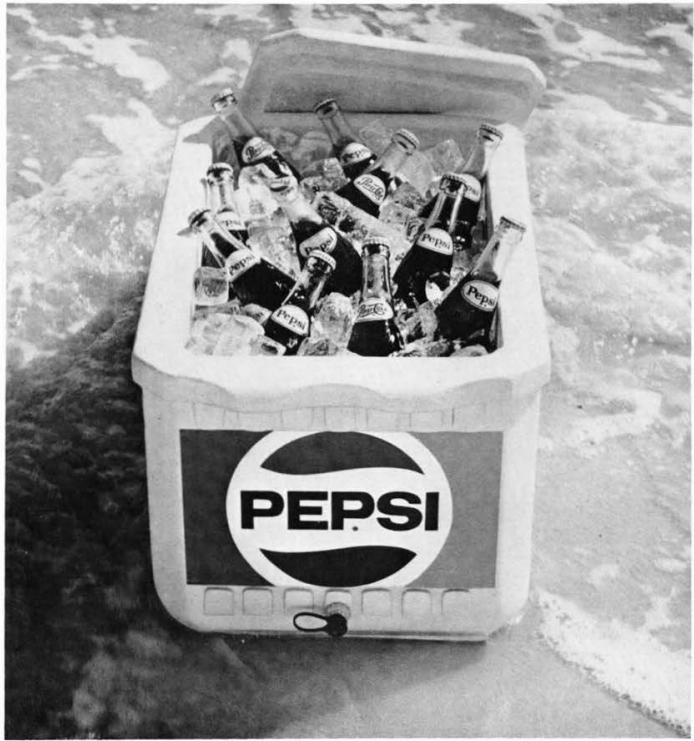

Put the perfect day on ice.

Pour everything you've got into a game of volleyball, baseball or football -

then put it all back with an ice-cold Pepsi-Cola.

Pepsi has the crisp, bold cola taste that turned on

a whole generation.

And when it comes to putting back energy -

Pepsi beats all the others-cold!

\section{You've got a lot to live. Pepsi's got a lot to give.}




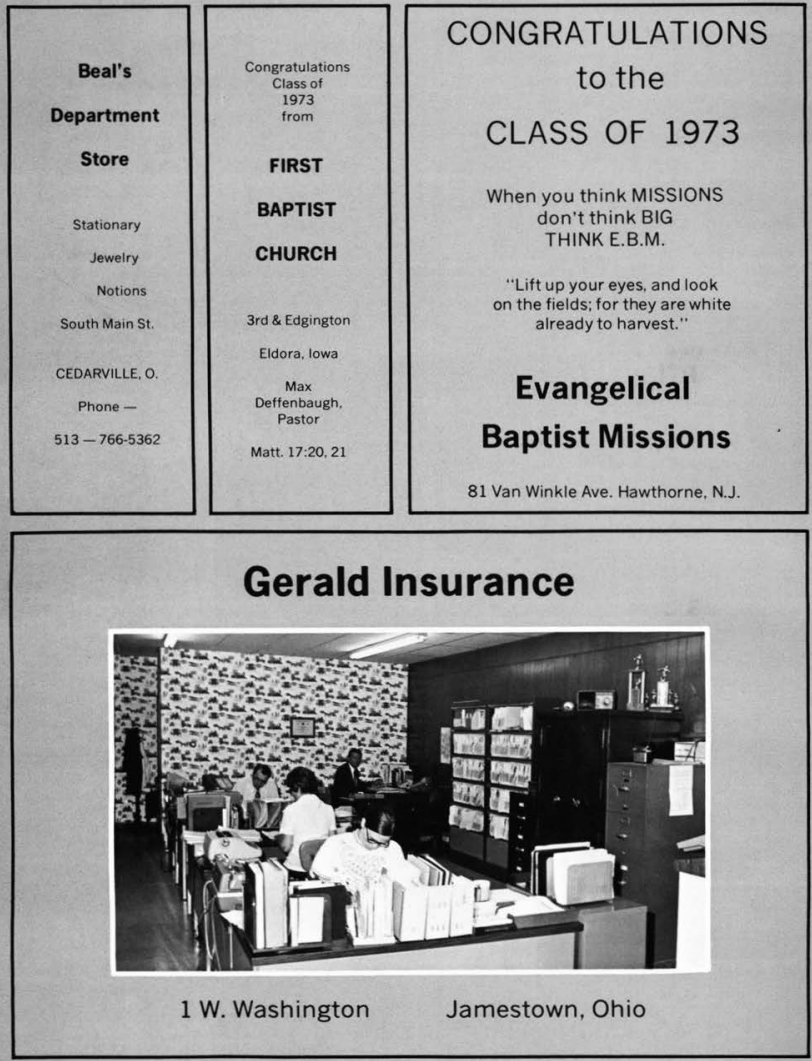




\title{
Grandview Park Baptist Church
}

\author{
1701 East 33rd. St. Des Moines, lowa \\ Dr. Paul Tassell, Pastor
}

"For the Word of God and Testimony of Jesus Christ"

David Morrison - Director of C.E. and Music Mark Bush - Minister of Youth

Rev. Elmer Carrithers - Minister of Visitation

David Keller - School Principal (K-8)

\section{PRATTSBURG VILLAGE BAPTIST CHURCH}

North Main Street

Prattsburg, New York

Rev. Wayne Keisling. Pastor

\section{FAITH BAPTIST CHURCH}

\section{Gallicolis, Ohio}

Orbin C. Morrison, Pastor

Wilbur Dennis, Ch. of Deacons

Congratulations Graduates of 1973

\section{Famous Sporting Goods}

64 East Main

Xenia, Ohio

"Specializing in the finest in team equipment"

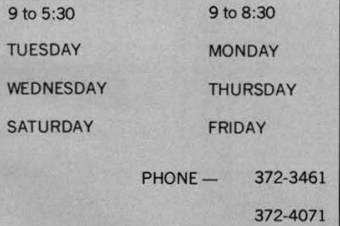

9 to $8: 30$

\section{THURSDAY}

FRIDAY

$372-4071$
CEDAR

\section{CLIFF}

\section{SUNDRIES}

- Cards

- Paper Products

- Gifts

- Candy

42 N. Main

Cedarville

Ohio

Phone 766-1771

\section{PARENT} PATRONS

Mr. \& Mrs. Clyde Mckanna Fort Jennings, Ohio Rev, \& Mrs. Robert McNeill Charleston, W. Va.

Ralph Melford

New Lisbon, Wisc.

Lloyd Miller

St Charles, lowa

Mr. \& Mrs. Thomas Molfit

Philadelphia. Pa.

Mr. \& Mrs. Gerald Mooney New Castle, $\mathrm{Pa}$.

Mr. \& Mrs. David Moreland Lavale, Md.

Dr. John B. Mulder Columbia, Missouri

Mr. \& Mrs. Richard E.

Muntis Sr.

Limo, Ohio

Mr. \& Mrs. John Nerreu Memphis, Tenn.

Mr. Denzil Nickell Fairborn, Onio

Mr. \& Mrs. Ernest Olsen Lima, Peru S.A.

Mr. \& Mrs. Paul Orwick Bluttton, Ohio

Mr. \& Mrs, Don O'Shell Oimsted Falls, Ohio

Mr. \& Mrs. Larry Park Hazel Park, Mich.

Mr. \& Mrs. Robert Podges Ashtabula, Ohio

Mr. \& Mrs. Loneal Potter Allegany. N.Y 


\section{LITCHFIELD BAPTIST CHURCH}

4200 Avon Lake Rd.

David L. Shimp, Pastor

Philippians 4:13

Students at Cedarville

Becky Wright

Debbie Rowland

Leonard Mohlar

\section{First Baptist Church}

276 Washington Ave.

Elyria, Ohio

Willis Hull, PASTOR

William McNiece, MIN. OF YOUTH

\section{FIRST BAPTIST CHURCH}

PRINCE and WATER STREETS

PRINCETON, IND.

Donald Grollimund, PASTOR

Miles Grismore, MIN. of YOUTH

"HOLDING FAST THE

FAITH WORD"

- TITUS 1:9

Congratulations Class of ' 73

\section{VILLAGE \\ RESTAURANT}

"In the Heart of

Cedarville"

COMPLETE FOOD SERVICE

PHONE: $766-5318$

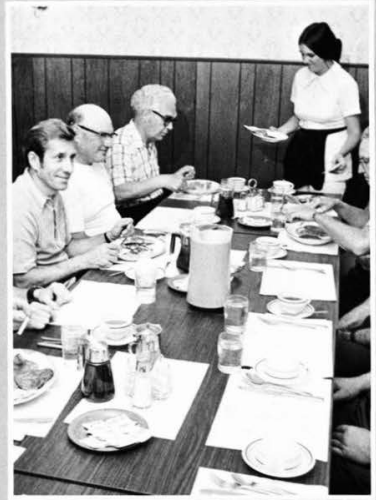




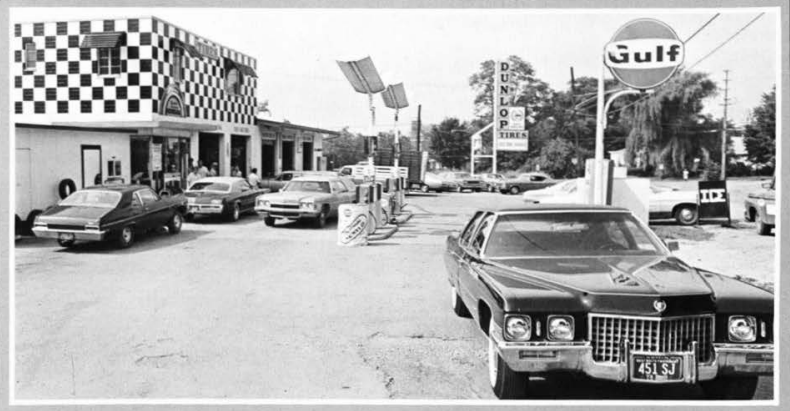

\section{ED'S TIRE And AUTO SERVICE}

\section{Calvary Baptist Church}

Congratulations

class of

1973

CRESAPTOWN, MARYLAND
- Weekly T.V. Ministry

- Active Bus Ministry

- Large Awana Club

- Soul-Winning Church
Rev. Roger

A. Mills,

PASTOR

\section{GRACE BAPTIST CHURCH}

1100 S. Fairfield Lombard, III.

Everett Hawbaker. PASTOR

"Our congratulations to the class of $1973^{\prime \prime}$

Our desire for each of you is to be faithful to Jesus Christ.

\section{West Endicott Baptist Church}

Birdsall at Mills St.

Endicott, New York John E. Trautman, PASTOR

Congratulations Class of ' 73 . 


\section{Immanuel Baptist Church}

3417 Palmetto Ave.

Columbus, Ohio

PHONE 274-2687

William E. Abernathy,

PASTOR

Proverbs 3:5, 6

\section{Jones Studio}

COLOR PHOTOGRAPHY

WEDDINGS - PORTRAITS

Corner Rt. 42 \& Miller

Phone 766-5533

\section{GRACE BAPTIST}

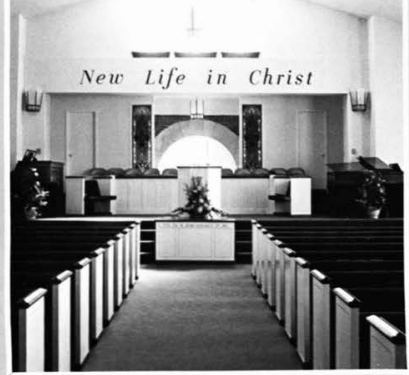

CHURCH

Cedarville, Ohio

William Broughton,

Pastor

Phone 766-4201 


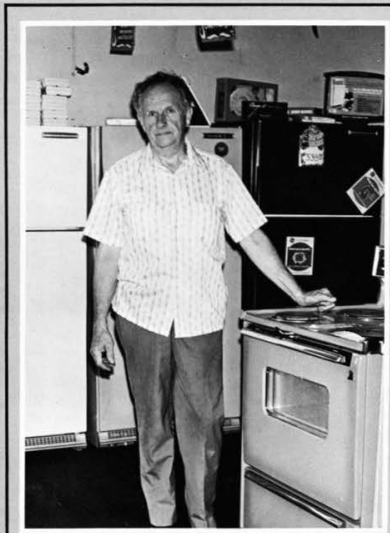

\section{PARENT PATRONS}

Mr. Lowell Prater

Oxon Hill, Md

Mr. \& Mrs. Andrew Protant

Parma. Ohio

Edward C. Portz

Greenville, Pa.

Ray Pycraft.

N. Ridgeville. Ohio

Mr. Roger Read

Hillsdale, Mich.

John \& Margie Reeder Sr.

Youngstown, Ohio

Mr. \& Mrs. Irwin Rehn

Boonton, N.J.

Wiliam $H$. Riess

Oklahoma City, Okla.

Mr. \& Mrs. Hacold Rifenberick

Corry, Pa.

Mr. \& Mrs. Rinehart

Noth Olmsted, Ohio

Drs. Wm. \& Bernice Roby London, Ohio

Mr. \& Mrs. Olin Rodgers Cuyahaga Falls, Ohio

Mr. \& Mrs. Lad Rodriguez Gary. Ind.

Mr. \& Mrs. Ernest Rogers Byesville, Ohio

Mr. \& Mrs. Allen Romaine

Gallipolis, Ohio

Donald \& Ruth Rost

Burbank III.

Mr. \& Mrs. Robert Rowe

De Ruyter, N.Y.
Harry Russell Jr.

East Brunswick, N I.

Mr. \& Mrs. Herman Salomon

Hamburg. N.Y.

Mr. \& Mrs. Guernsey Saunders

Port Jervis, N.J.

Mr. \& Mrs. Ralph Schnellbecher Quincey, III.

Mr. \& Mrs. Royal Schroeder

Royal Oak, Mich.

Mr. \&Mrs. Stan Schroedermeier Waterloo, lowa

Eric Schulz

Millwaukee, Wisc

Rev. \& Mrs. David Selden Huntsburg, Ohio

Mr. \& Mrs. Lawrence Seigneur Stryker, Ohio

Mr. \& Mrs. Earle Severs

Hamilton Square, N.J.

Mr. \& Mrs. Francis Shank

New Madison, Ohio

Mr. \& Mrs. Lloyd Shaw

Naples, Florida

Mr. \& Mrs, Donald Shawver Lorain, Ohic

Mr. \& Mrs. R. Gary Sheppard Haddon Hts. N.J.

Mr. \& Mrs. William Sims

Waterioo, Iowa

Mr. \& Mrs, E.J. Skees

Angola, Ind

Mrs. R. Skinner

Dayton, Ohio

\section{CEDARVILLE HARDWARE}

- HARDWARE

- HOUSE WARES

- GIFTS

- G.E. APPLIANCES

"For More Than A Quarter Century"

\section{North Baptist Church}

\section{St. Paul Street at Ridge Road}

Rochester, N.Y.

Rev. Ralph E. Gruenburg, Pastor

PS. 9:10"They that know thy name will put their trust in thee: for thou, Lord, hast not forsaken them that seek thee."

\section{FAITH INDEPENDENT BAPTIST CHURCH}

301 Shaw St. Frostburg, Maryland

"Holding Forth The Word of Life"

- Phil 2:16

STUDENTS AT CEDARVILLE: Sue Cook Steve Russell 


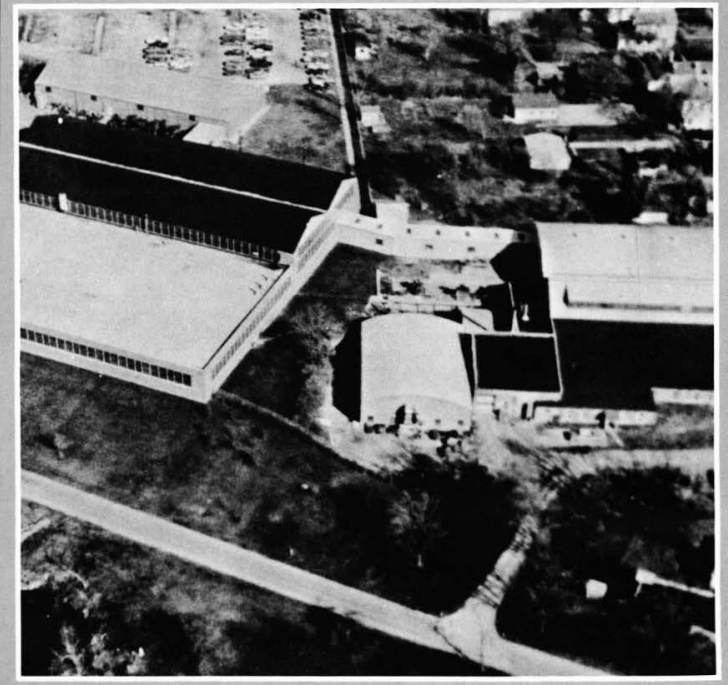

\section{MORRIS BEAN AND $\mathrm{CO}$.}




\title{
PARENT PATRONS
}

Mr, \& Mrs. L. Sloan

Lima, Ohio

Mr. \& Mrs. Clayton Small

Montrose, Pa.

Mr. \& Mrs. Maynard Smart

Kettering, Ohio

Mr. \& Mrs. Lester Smith

Upper Arlington, Ohio

Mr. \& Mrs. Stanley Snoke

Aurora, III.

Mr. \& Mrs. Wm. E. Soeder

Euclid, Ohio

Frank P. Soper

Wenonah, $\mathrm{N}$.

Genevieve Soule

Lake Orion, Mich.

Dr. \& Mrs. S. A. Spink

Belfast, N. Y.

Mr. \& Mrs. David Steere

Pontiac, III.

Mr. \& Mrs. Startord Steinhof

Buffalo, N. Y.

Mr. \& Mrs. Homer Stewart

Gien Mills, Pa.

Mr. \&. Mrs. Howard Stone

Watertord, $\mathrm{Pa}$

Stanley Strychalski

Lebanon, Ind

Mr \& Mrs. Thomas Syphers

Bay Village, Onio

Mr. \& Mrs. John Theetge

Big Flots. N. Y

Jeanette Thomas

Dayton, Ohio

Mr. 8 Mrs. Eugene Thompson

South Bend. Ind.

Mr \& Mrs. Edward Tink

Waterioo, lowa

Mr \& Mrs Lestie Towle

Dover, N. H.

Rev \& Mrs C.L. True

La Habre, $\mathrm{Ca}$

James Trueblood

Griffith, Ind

Mr. \& Mrs. Albert Tucker

Xenia, Ohio

Donald Turner

Grinnell, lowa
Mr. \& Mrs, John Unthank

West Manchester, Ohio

Pastor \& Mrs. Allan Vine

Arcanum, Ohio

Dr. \& Mrs. Thomas Watker

Brownsburg. Ind

Mr. \& Mrs. Robert Wagner

San Diego. C

Richard L. Waiker

thaca, N. Y.

Hiram J. Waiter

Westmont, N.J.

Rev. \& Mrs Walter Wartield

Schaumburg, III.

Barbara \& Arthur Warner

Flushing, Mich

Mr. \& Mrs. Sam Watson

Mishawaka. Ind

Mr. \& Mrs. Warren Weber

Conneaut Lake, Pa.

Mr. \& Mrs. Raymond Woeks

Battle Creek. Mich.

Mr. \& Mrs. Oscor Weiss

Hamburg, N.Y

Paut Wheeler

Huntington, W. Va.

Gail E. White

Springtield, Ohio

Mr. \& Mrs, Claude Williams

Reynoidsburg, Ohio

Mr.\&. Mrs. Marshall Williams

Wood River, III:

Rev. \& Mrs. Gordon Wimer

Sarh, Rep du Tchad

Mr. \& Mrs. H. M. Wineburg

DuBois, $\mathrm{Pa}$.

Mr. \& Mrs. Arthur Wood

Kokomo, Ind

Mr. \& Mrs. Gordon Wood

Curwenswille, $\mathrm{Pa}$.

Mr. \& Mrs. R. A. Wolfe

Dublin, Onio

Mr. \& Mrs. Wayne Van Wyk

Monroe, lowa

Edwin H. Wyman

Sarasota, Florida

Mr, \& Mrs, Charles Wymer

Warren, Ohio

\section{Clintonville} Baptist Church

\author{
35 OAKLAND PARK AVE.
}

COLUMBUS, OHIO

GEORGE HATTENFIELD, PASTOR

Congratulations Class of 1973

\section{College Hill IGA}

\author{
CEDARVILLE, OHIO
}




\section{Southgate Baptist Church}

227 BASSETT DR.

SPRINGFIELD, 0 .

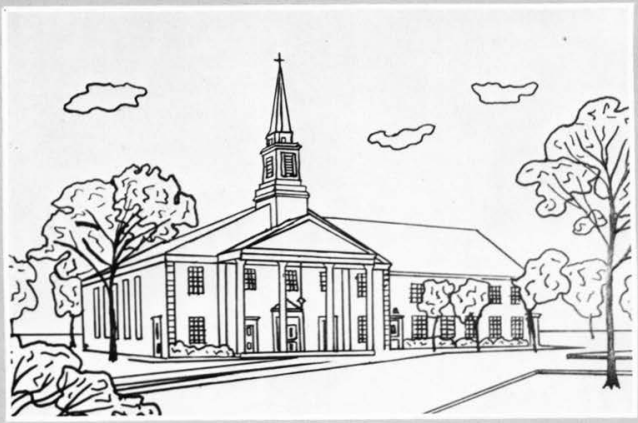

Congratulations Class of 1973

"And God said to man, behold the fear of the Lord that is wisdom; and to depart from evil is understanding." Job 28:28 


\section{Faculty Patrons}

Debora, Steve and Dave Gidley Mr. \& Mrs. Edward L. Greenwood Dr. \& Mrs. Walter L. Griffeth Ronald M. Grosh Dr. \& Mrs. Clifford Johnson Rusty and Sheri King Dr. Allen Monroe

James and Pamela Rickard Mr. \& Mrs. Edward E. Spencer

\section{Larry Manuel Plumbing}

RR 25878 Lightner Blvd.

TIPP CITY, OHIO

Contact at New Science Center

THANKS TO MR. RAYBURN

AND TO CHARLIE MILLER

FOR THEIR HELP IN PUTTING

OUT THIS BOOK.

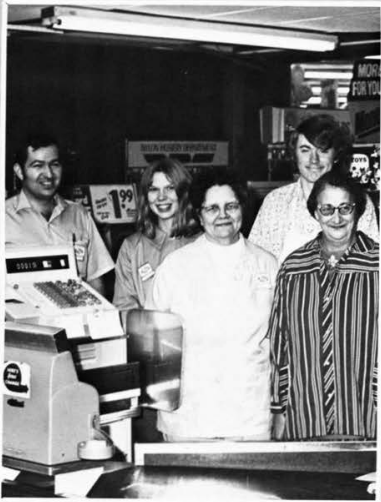

\section{WAYNE'S \\ SUPER VALUE}

\author{
10 NORTH MAIN
}

Cedarville, Ohio 
sometimes i have reached out for people,

places,

or things

and have been disappointed. all of these are so temporary.

yet the emphasis at cedarville is on a person who is permanent.

in Him i have never been

disappointed...

when i reached out He was there...

He still is there.

His name is Jesus Christ.

we all can depend on Him.

bob mahl 



